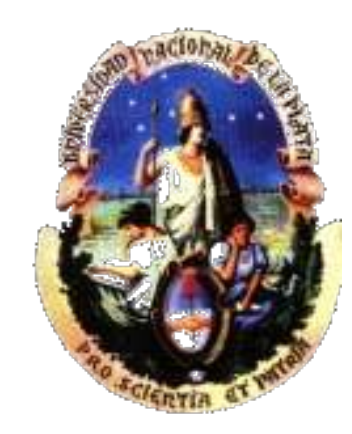

\title{
Cancro Bacteriano del Tomate: Diagnóstico y Prevención de su Dispersión en el Cultivo
}

\author{
Tesis presentada para optar al titulo de Magister Scientiae de la Facultad de Ciencias \\ Agrarias y Forestales. Universidad Nacional de La Plata
}

\section{Jorgelina Rolleri}

\author{
Ingeniera Agrónoma
}

2 de diciembre de 2015

Facultad de Ciencias Agrarias y Forestales -Universidad Nacional de La Plata

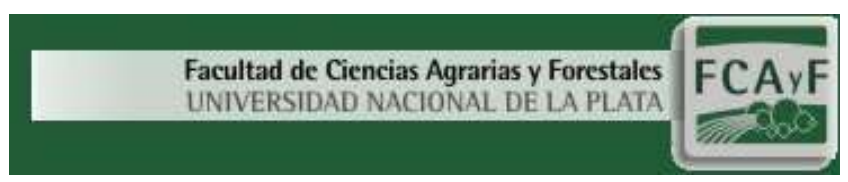




\author{
Directora de Tesis \\ Ana María Romero \\ Ingeniera Agrónoma (Universidad de Buenos Aires) \\ Doctor of Philosophy (North Carolina State University, Estados Unidos)
}

Comité Evaluador

Ing. Agr. Doctor of Philosophy Blanca Isabel Canteros

Ing. Agr. M. Sc. Diana Frezza

$P h \mathrm{D}$. Adrián Vojnov 
Dedicado a mis niñas, Morena y Angelina. 


\section{AGRADECIMIENTOS}

Agradezco especialmente a mi directora, Ana María Romero, por su dedicación y enseñanza, por haberme ayudado a completar mi formación profesional, no sólo por haber sido una excelente guía en este trabajo en aspectos académicos sino también por su calidad humana.

A Elena Dal Bó, por su guía y colaboración fundamentales para llevar adelante los análisis serológicos.

A Susana Gamboa, por su orientación y sugerencias en lo relacionado al cultivo de tomate y los ensayos de campo.

Al personal de campo de la Estación Experimental Gorina por ayudarme en el cuidado y mantenimiento de los ensayos.

A Rodrigo Altamirano por orientarme en los análisis estadísticos y a Laura Balagué por su ayuda en las determinaciones microbiológicas.

A Eliana Wasserman por su colaboración en las determinaciones moleculares.

A la Facultad de Ciencia Agrarias y Forestales de la Universidad Nacional de La Plata y al Ministerio de Asuntos Agrarios de la Provincia de Buenos Aires por haberme brindado el espacio y los recursos necesarios.

A mis compañeros del CIDEFI por su apoyo y confianza, y a mi familia. 


\section{INDICE GENERAL}

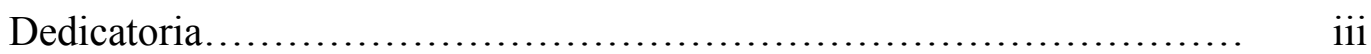

Agradecimientos.............................................. iv

Índice general ..................................................

Índice de cuadros ............................................. viii

Índice de figuras............................................... ix

Resumen.................................................... xii

Abstract.......................................................... xiii

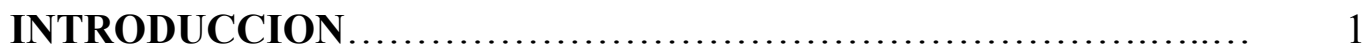

Presentación del tema............................................... 1

Antecedentes

El cultivo del tomate........................................ 2

El cancro bacteriano del tomate...................................... 3

Fuentes de inóculo primario y secundario......................... 5

Descripción de síntomas......................................... 7

Colonización del tejido de la planta.............................. 9

Manejo de la enfermedad...................................... 10

Características de la bacteria.................................... 11

Métodos de diagnóstico.......................................... 12

Panorama local.............................................. 13

Objetivo General............................................. 14

Objetivos Específicos........................................ 14 
CAPITULO I: Relevamiento de campo del "cancro bacteriano del tomate" en el Cinturón Hortícola Platense.

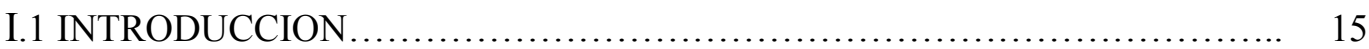

I.2 MATERIALES Y METODOS ............................................ 18

I.2.1 Relevamiento de plantas para determinar incidencia y prevalencia............ 18

I.2.2 Aislamiento e identificación del patógeno.................................. 19

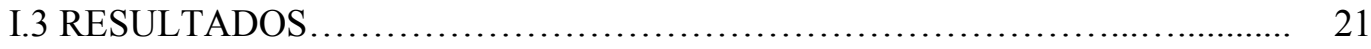

I.3.1 Relevamiento en invernaderos........................................ 21

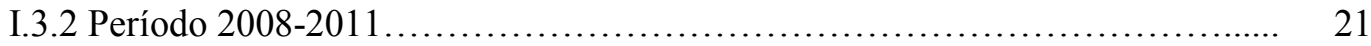

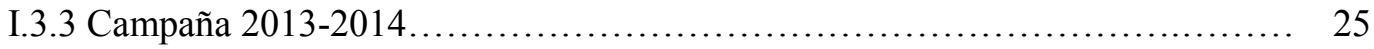

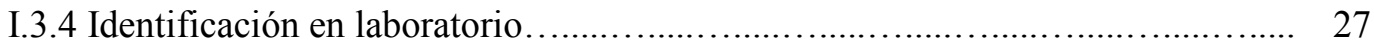

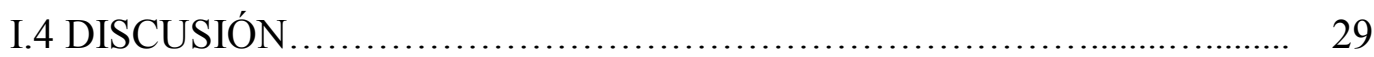

I.5 CONCLUSIONES...................................................... 31

CAPITULO II: Detección de Clavibacter michiganensis subsp. michiganensis en plantas de tomate con infecciones latentes............................... 32

II.1 INTRODUCCION ............................................... 32

II.2 MATERIALES Y MÉTODOS....................................... 36

II. 2.1 Cultivo e inoculación de plantas...................................... 36

II. 2. 2 Aislamiento e identificación del patógeno por técnicas convencionales...... 37

II. 23 Serología...................................................... 38

II. 2. 4 Análisis de los datos............................................. 40

II. 3 RESULTADOS ..................................................... 41

II. 3. 1 Método convencional............................................... 41

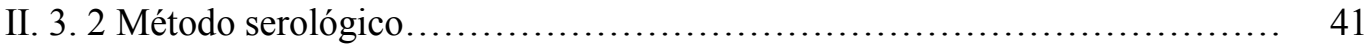

II.3.3 Comparación de métodos.......................................... 42

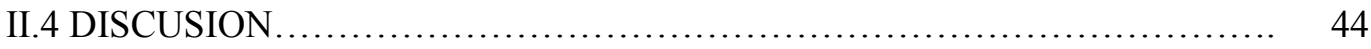

II. 5 CONCLUSIONES.................................................. 45 
CAPITULO III: Desinfección de las herramientas de corte durante la conducción del cultivo de tomate...................................................... 46

III. 1 INTRODUCCION .................................................... 46

III. 2 MATERIALES Y MÉTODOS.......................................... 49

III. 2. 1 Diseño del experimento........................................... 49

III. 2. 2 Inoculación y aplicación de tratamientos............................... 49

III. 2. 3 Evaluación..................................................... 50

III. 3 RESULTADOS ............................................... 52

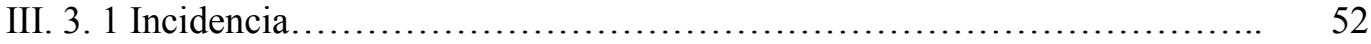

III. 3. 2 Altura alcanzada por los síntomas.................................. 54

III. 3. 3 Area Bajo la Curva de Progreso de la Enfermedad (ABCPE)............... 56

III. 3. 4 Rendimiento...................................................... 57

III.4 DISCUSION .................................................... 58

III. 5 CONCLUSIONES.................................................. 60

CONCLUSIONES GENERALES......................................... 61

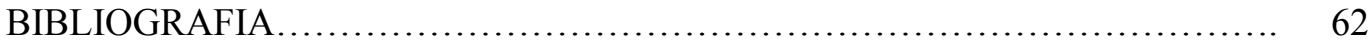




\section{INDICE DE CUADROS}

Cuadro I. 1: Incidencia del cancro bacteriano en plantas de tomate en relevamientos realizados en el Cinturón Hortícola Platense, según localidad, híbrido de tomate y cultivo antecesor en el período 2008-2011.

Cuadro I. 2: Frecuencia de invernaderos afectados con el cancro bacteriano del tomate por año y localidad e incidencia promedio de plantas enfermas por año.

Cuadro I. 3: Prevalencia e incidencia promedio del cancro bacteriano en invernaderos del CHP según cultivo antecesor; años 2008-2011.

Cuadro I. 4: Incidencia del cancro bacteriano en plantas de tomate en relevamientos realizados en el Cinturón Hortícola Platense, según localidad, híbrido de tomate y cultivo antecesor en el año 2014.

Cuadro I. 5: Prevalencia e Incidencia promedio del cancro bacteriano en invernaderos del CHP por localidad en el año 2014.

Cuadro I. 6: Prevalencia e Incidencia promedio del cancro bacteriano del tomate en invernaderos del CHP según el cultivo antecesor, año 2014.

Cuadro I. 7: Prevalencia e Incidencia promedio del cancro bacteriano del tomate en invernaderos del CHP según el tipo comercial de tomate.

Cuadro III. 1: Rendimiento promedio por planta para cada tratamiento.

Años 2010 y 2011 


\section{INDICE DE FIGURAS}

Figura 1: Diseminación de la enfermedad en la hilera del cultivo a través de las herramientas de trabajo que ocasionan el marchitamiento y muerte de las plantas...... 6

Figura 2: Síntomas locales: a la izquierda manchas necróticas internervales. A la derecha manchas necróticas marginales en los folíolos

Figura 3: Síntomas sistémicos: a la izquierda folíolos que pierden turgencia por la infección vascular "hoja de trapo". A la derecha marchitamiento y necrosis unilateral de la hoja....

Figura 4: Síntomas en tallo y fruto. A la izquierda cancros en tallo que dan el nombre a la enfermedad. A la derecha se observan los síntomas típicos en fruto llamados "mancha en ojo de pájaro".

Figura I.1:Localidades muestreadas en el Cinturón Hortícola Platense, los puntos de colores representan los invernaderos visitados.

Figura I. 2: Detección de Clavibacter michiganensis subsp. michiganensis a partir de cultivo bacteriano. De izquierda a derecha muestras 1 a 9, Control negativo, Ladder y Control positivo. Las bandas amplificadas corresponden a la fracción del gen pat-1 de $614 \mathrm{pb}$.

Figura II. 1: Valores de absorbancia para las hojas 5 y 7 de plantas de tomate en cuatro momentos después de la inoculación. Líneas continuas de hojas 5 y 7 corresponden a plantas inoculadas y líneas de puntos a testigo con agua. La densidad óptica fue medida a $405 \mathrm{~nm}$. Letras minúsculas diferentes sobre las curvas indican diferencias significativas $(p=0.000018$; test de Tukey, $\alpha=0,05)$.

Figura II. 2: Porcentaje de plantas de tomate inoculadas con Clavibacter michiganensis subsp. michiganensis que presentaron síntomas, y en las que se detectó el patógeno por un método serológico (ELISA) o convencional, evaluadas en cuatro ocasiones post inoculación.

Figura II. 3: Porcentaje de plantas de tomate inoculadas con Clavibacter michiganensis subsp. michiganensis en las que se detectó el patógeno por un método serológico y otro método convencional. A la izquierda resultados de la hoja 5; a la derecha de la hoja 7. 43

Figura III. 1: Distribución del cancro bacteriano en la hilera de cultivo. Transmitido por las herramientas de trabajo en el momento de las labores culturales

Figura III.2: Esquema representando la distribución de tratamientos dentro de un bloque. Cada bloque consistió de dos hileras de plantas. Las plantas están representadas con una X. Las rojas son plantas usadas como bordura para separar tratamientos. 
Figura III. 3: Incidencia de plantas con cancro bacteriano, para los distintos desinfectantes de herramientas. Año 2010. Tratamientos: 1-Cloruro de Benzalconio (1\%), 2, Sulfato de oxiquinoleína $(0,01 \%), 3$ - Hipoclorito de sodio (1\%), 4-Agua, 5Testigo Inoculado, 6-Testigo sano. Letras minúsculas diferentes sobre las curvas indican diferencias significativas.

Figura III. 4: Incidencia de plantas con cancro bacteriano, para los distintos desinfectantes_de herramientas. Año 2011. Tratamientos: 1-Cloruro de Benzalconio $(1 \%), 2$, Sulfato de oxiquinoleína $(0,01 \%), 3$ - Hipoclorito de sodio (1\%), 4-Agua, 5 Testigo inoculado, 6-Testigo sano. Letras minúsculas diferentes sobre las curvas indican

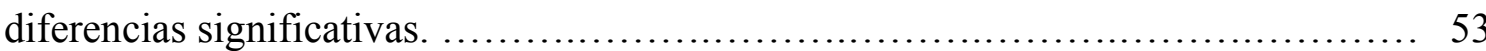

Figura III. 5: Altura (cm) alcanzada por los síntomas de la enfermedad para los distintos desinfectantes de herramientas. Año 2010. Tratamientos: 1-Cloruro de Benzalconio $(1 \%), 2$, Sulfato de oxiquinoleína $(0,01 \%), 3$ - Hipoclorito de sodio (1\%), 4-Agua, 5 Testigo Inoculado, 6-Testigo Sano. 14 repeticiones y tres plantas por tratamiento en cada repetición. .......................................................... 55

Figura III. 6: Altura (cm) alcanzada por los síntomas de la enfermedad para los distintos desinfectantes de herramientas. Año 2011. Tratamientos: 1-Cloruro de Benzalconio $(1 \%), 2$, Sulfato de oxiquinoleína $(0,01 \%), 3$ - Hipoclorito de sodio (1\%), 4-Agua, 5 Testigo Inoculado, 6-Testigo Sano. 14 repeticiones y tres plantas por tratamiento en cada repetición.

Figura III. 7: Area Bajo la Curva de Progreso de la Enfermedad correspondiente al año 2010. Tratamientos: 1-Cloruro de Benzalconio (1\%), 2, Sulfato de oxiquinoleína (0,01\%), 3- Hipoclorito de sodio (1\%), 4-Agua, 5-Testigo Inoculado, 6-Testigo Sano. Letras minúsculas diferentes sobre las barras indican diferencias significativas. ABCPE: Calculada a partir de altura alcanzada por el síntoma de la enfermedad, con 14 repeticiones y tres plantas por tratamiento en cada repetición..................... 56

Figura III. 8: Area Bajo la Curva de Progreso de la Enfermedad correspondiente al año 2011. Tratamientos: 1-Cloruro de Benzalconio (1\%), 2, Sulfato de oxiquinoleína (0,01\%), 3- Hipoclorito de sodio (1\%), 4-Agua, 5-Testigo Inoculado, 6-Testigo Sano.

Letras minúsculas diferentes sobre las barras indican diferencias significativas. ABCPE:

Calculada a partir de altura alcanzada por el síntoma de la enfermedad, con 14 repeticiones y tres plantas por tratamiento en cada repetición. 


\section{RESUMEN}

El cancro bacteriano del tomate es producido por la bacteria Clavibacter michiganensis subsp. michiganensis; está presente en prácticamente todas las zonas productoras de tomate del mundo. En el Cinturón Hortícola Platense (CHP) se lo encuentra, aunque no hay trabajos sistemáticos de relevamiento de campo que permitan cuantificar su magnitud. Se transmite rápidamente en el cultivo bajo invernadero, principalmente llevado por las herramientas de corte durante las labores culturales, muchas veces a partir de plantas asintomáticas. El objetivo de este trabajo fue determinar su prevalencia e incidencia en invernaderos de la zona, establecer un método de diagnóstico que permita detectar la bacteria en infecciones latentes y evaluar la efectividad de distintos desinfectantes sobre las herramientas de trabajo. Entre los años 2008-2011 y en el 2014 se realizaron muestreos en invernaderos del CHP. Se analizaron plantas inoculadas para comparar la sensibilidad de dos métodos de diagnóstico, uno convencional con siembra en medio de cultivo general y otro inmunoenzimático DAS-ELISA. Para la desinfección de las cuchillas de corte se evaluaron los siguientes productos: cloruro de benzalconio (1\%), sulfato de oxiquinoleína $(0,01 \%)$ e hipoclorito de sodio (1\%). La prevalencia registrada durante 2008-2011 y en 2014 fue de $86 \%$ y $93 \%$, respectivamente, con una incidencia promedio de $30 \%$ y $15 \%$ para cada período. Con el método serológico se detectó la bacteria en plantas asintomáticas 15 días antes que con el tradicional. Todos los desinfectantes mostraron diferencias significativas con el testigo, siendo ligeramente mejor el cloruro de benzalconio ( $1 \%)$. Se concluye que la enfermedad es prevalente en el CHP, con una alta incidencia en los invernaderos donde se presenta: el método DAS-ELISA permite hacer un diagnóstico rápido en plantas asintomáticas; y para evitar la propagación en el cultivo es conveniente desinfectar las herramientas de corte con cloruro de benzalconio o algún otro de los desinfectantes evaluados. 


\begin{abstract}
The tomato bacterial canker, produced by Clavibacter michiganensis subsp. michiganensis, is present in almost every tomato producing area of the world. It is also present in the horticultural belt of La Plata (Cinturón Hortícola Platense - CHP), although its relevance is unknown since there has not been systematic surveys. The disease is readily transmitted within a greenhouse, mainly in cutting tools during regular cultural activities, in many occasions from asymptomatic plants. The objective of this research was to determine bacterial canker incidence and prevalence in greenhouses of the CHP; to establish an appropriate diagnostic method to detect latent infections; and to evaluate the efficacy of different tools' disinfectants. To this purpose, plant samples were collected in CHP greenhouses from 2008 to 2011, and in 2014. Also, inoculated plants were analyzed to compare the sensibility of two different diagnostic methods, one conventional (isolation in culture medium) and an immunoenzymatic DAS-ELISA technique. The following tool disinfectants were evaluated: benzalkonium chloride $(1 \%)$, oxyquinoline sulfate $(0.01 \%)$ and sodium hypochlorite (1\%). The disease prevalence was $86 \%$ and $93 \%$ during the 2008 2011 and 2014 periods, respectively, with an average incidence of $30 \%$ and $15 \%$ for each period. The pathogen was detected in asymptomatic plants 15 days earlier with the serologic method than with the traditional technique. All tested disinfectants significantly reduced disease transmission; benzalkonium chloride (1\%) showed a slightly better result. This research concludes that tomato bacterial canker is a prevalent disease in CHP with high incidence in greenhouses where the pathogen is present, the DAS-ELISA method allows for an earlier diagnosis in asymptomatic plants, and that to prevent disease transmission it is recommended to disinfect cutting tools with benzalkonium chloride (1\%) or any other of the evaluated disinfectants.
\end{abstract}




\section{INTRODUCCION}

\section{Presentación del tema}

El tomate es la principal hortaliza de consumo fresco de la Argentina y el cultivo hortícola con mayor superficie destinada bajo invernadero. La provincia de Buenos Aires concentra el 34,4\% de esa superficie, la mayor parte de la cual está ubicada en el cinturón hortícola Platense (CHP) (Corvo Dolcet 2005). En esta zona, el cancro bacteriano del tomate afecta seriamente los cultivos; con anterioridad a este trabajo se han observado casos en los que la mayoría de las plantas estaban afectadas. Sin embargo, se desconoce si se trata de casos aislados, o por el contrario, si son muchos los invernaderos afectados, así como el nivel promedio de la incidencia de plantas enfermas en los mismos. Este conocimiento es necesario para poder tomar decisiones fundamentadas en el alcance real del problema, tanto para los productores individuales, asociaciones de productores, $\mathrm{u}$ otros organismos privados o públicos.

Las semillas y plantines infectados son una fuente de inóculo primario muy importante de la enfermedad. Debido a que los plantines suelen estar asintomáticos al momento del trasplante, el patógeno es introducido inadvertidamente en los invernaderos de producción (Chang y col. 1992; Ricker y Riedel 1993; de León y col. 2011). Otra fuente de inóculo importante son los rastrojos infestados que quedan del ciclo del cultivo anterior, los que pueden dar origen a plantas enfermas que no siempre manifiestan síntomas debido al largo período de incubación que tiene el agente causal (Kawaguchi 2014). La dispersión secundaria del patógeno se produce durante las labores culturales de desbrote y deshoje, por lo tanto es crucial la desinfección de las cuchillas y tijeras de trabajo (Rista y col. 2005b; Vega y col. 2009) con productos de probada efectividad, baja toxicidad para el operario que realiza las labores y fácilmente disponibles en el mercado.

Debido a que las plantas enfermas no siempre manifiestan síntomas, es necesario disponer de un método confiable y rápido que permita hacer un diagnóstico certero no solo una vez que las plantas presentan síntomas, sino también cuando están aún asintomáticas. 


\section{Antecedentes}

\section{El cultivo de tomate}

El tomate (Solanum lycopersicum L. = Lycopersicon esculentum Mill.) es una planta dicotiledónea perteneciente a la familia de las solanáceas (Peralta y Spooner 2005). Es una de las hortalizas más consumidas y distribuidas en todas las regiones del mundo.

Es originario de América del sur, entre las regiones de Chile, Ecuador y Colombia, considerando como el centro de origen al de las especies relacionadas al ancestro más seguro, S. lycopersicum var. cerasiforme (Peralta y col. 2005). El tomate ya no se encuentra en forma silvestre. Su domesticación se inició en el sur de México y norte de Guatemala (Pérez y col. 1997). Con la llegada de los españoles el cultivo se extendió al continente europeo y de ahí a todo el mundo. En el siglo XVI e inicios del XVII, el tomate fue cultivado en los jardines de Europa (Italia, Inglaterra, España y Francia) como ornamental. Posiblemente Italia haya sido el primer país que utilizó el tomate en la alimentación humana, a mediados del siglo XVIII. Después de haber llegado a Inglaterra, fue llevado a Estados Unidos, donde su consumo como alimento ocurrió aproximadamente en 1850. En el siglo XIX comenzó a tener importancia económica mundial, hasta llegar a ser junto con la papa, la hortaliza más difundida y predominante del mundo (Jaramillo y col. 2007).

En Argentina es la segunda hortaliza más consumida después de la papa. El consumo de tomate es de $15 \mathrm{~kg} / \mathrm{hab} / \mathrm{año}$. Del total producido un 60-65\% se consume en fresco, mientras que entre un 35-40\% se industrializa (MCBA, 2011). Tiene bajo valor calórico (17 $\mathrm{kcal} / 100 \mathrm{~g}$ ), un alto contenido de azúcares solubles (glucosa, fructuosa y sacarosa) y un destacado aporte de vitaminas (A y C), carotenoides y elementos minerales (USDA 1999; Fernández-Ruiz y col. 2004). Los carotenoides, como el licopeno, funcionan como antioxidantes cumpliendo un importante rol en la prevención de enfermedades (Gerster 1997; Jaramillo y col. 2007).

El tomate es una de las hortalizas más importantes por su consumo, superficie cultivada y por la tecnología desarrollada en torno a él. La producción mundial de tomate fresco es de 161.793.834 t (FAOSTAT 2013); se encuentra dentro de los diez alimentos de mayor producción a nivel mundial. El continente que mayor superficie destina a su cultivo es Asia, 
siendo China el país que ocupa el primer lugar. Europa se destaca por la alta calidad, y en algunos países la implementación de nuevas tecnologías permite, además de calidad, altos rendimientos. Sin embargo, su cultivo se ve limitado a los países más cálidos como Italia y España. En América del Norte se destaca Estados Unidos, que es un importante consumidor de tomate fresco e industrializado, y en Sudamérica el principal productor es Brasil seguido por México (FAOSTAT 2013).

En Argentina, la superficie total destinada a tomate se estima en 17.800 ha (INTA 2009). Es la hortaliza que ocupa mayor superficie cultivada bajo cubierta del país, representando el 40\% del total (Corvo Dolcet 2005), concentrada principalmente en las provincias de Buenos Aires y Corrientes. Si bien es cultivado en todos los cinturones verdes, existen también zonas especializadas. Para consumo en fresco las zonas más importantes son el NOA (Salta, Jujuy, Santiago del Estero y Tucumán), el NEA (Corrientes), y la provincia de Buenos Aires (La Plata, Berazategui, Florencio Varela y Mar del Plata), y en menor medida el Alto Valle de Río Negro y Cuyo (Mendoza y San Juan). En tomate para industria se destaca principalmente Cuyo, el Alto Valle de Rio Negro y el NOA (Salta y Jujuy) (Corvo Dolcet 2005).

El CHP no sólo es la región más importante de la provincia de Buenos Aires, sino que además es una de las zonas productivas más capitalizadas de la Argentina. Esto fue impulsado en los últimos 20 años por la continua incorporación de los invernaderos que han permitido su crecimiento en producción a nivel regional, provincial y nacional (García 2011).

\section{El cancro bacteriano del tomate}

El cancro bacteriano del tomate es producido por la bacteria Clavibacter michiganensis subsp. michiganensis (Smith 1910; Davis y col.1984) (Cmm). Se encuentra presente en prácticamente todas las zonas productoras de tomate del mundo (Shirakawa y col. 1991; EPPO/CABI 1998; de León y col. 2011). Está citado en Asia: Armenia, China, Irán, Israel, Japón, Turquía, República de Korea; Africa: Egipto, Kenya, Madagascar, Sudáfrica,

Uganda; Europa: Francia, Grecia, Alemania, España, Italia, Rusia, Suiza; Oceanía: Australia; América del Norte: Canadá, México, EE.UU.; América Central y Caribe: Costa 
Rica, Cuba, República Dominicana, Panamá, y América del Sur: Argentina, Brasil, Colombia, Perú, Chile y Uruguay (CABI, 2014).

Ha causado grandes pérdidas en los cultivos de tomate tanto a campo como en invernadero. El síntoma más relevante es el marchitamiento y muerte de las plantas, lo que ocasiona grandes pérdidas económicas (Gleason y col. 1993; CABI 2014). Cuando se presenta puede acabar con todas las plantas en parcelas o invernaderos en poco tiempo (EPPO 2010). Las pérdidas que ocasiona pueden variar con el año, la ubicación, el cultivar y el estado fenológico de la planta en el momento de la infección (Chang y col. 1992; Poysa 1993 y Sen y col. 2015). En Ontario, Canadá, se registraron pérdidas de rendimiento en cultivos comerciales del 84 \% (Poysa 1993), 20-30 \% en Francia (Rat y col. 1991), 46 \% en Illinois, EE.UU. (Chang y col. 1992), y en Queensland, Australia, el rendimiento se redujo 10 veces tras la pérdida de plantas (Dullahide y col. 1983). En los últimos años ha habido varios reportes de cancro bacteriano en diversos países de Asia, Europa, América del Norte y Sudamérica. Algunos de los países donde se han informado grandes epidemias son: Bélgica, Israel, Japón, México y en las Islas Canarias, España (de León y col. 2009; Kleitman y col. 2008; Borboa Flores y col. 2009; Zaluga y col. 2013). Estas pérdidas de rendimiento se reflejan en importantes daños económicos a la producción (Hausbeck y col. 2000).

Actualmente se lo incluye en la categoría A2 de la lista de enfermedades cuarentenarias de la Organización Europea de Protección de las Plantas (EPPO), en la Comisión de protección de las Plantas de Asia y el Pacífico (APPPC), en la Comisión de Protección de las Plantas del Caribe (CPPC) y el Consejo Fitosanitario Interafricano (IAPSC), esto se refiere a toda plaga que está presente en un área pero con distribución limitada y mantenida bajo control oficial en el país o países detectados, debiéndose mantener bajo control fitosanitario para evitar su diseminación (Janse 2006; EPPO 2015).

En la República Argentina su presencia fue informada en las provincias de Jujuy, Mendoza, Corrientes, La Rioja, Misiones, Santa Fé, Formosa, Rio Negro, Salta, Buenos Aires y Chaco (Atlas Fitopatológico Argentino 2015).

Esta bacteria, junto a Ralstonia solanacearum, que causa el marchitamiento bacteriano, ha afectado más del $30 \%$ de los invernaderos de tomate para consumo fresco del país (INTA 2011). Relevamientos preliminares realizados en el CHP a partir de la campaña 2007-2008 
indican que el cancro bacteriano del tomate está muy difundido en la zona. Sin embargo, no hay trabajos sistemáticos de relevamiento que permitan conocer de manera objetiva su importancia local.

El tomate es el hospedante principal de $\mathrm{Cmm}$, pero se han reportado infecciones naturales en pimiento (Capsicum anuum L.) y berenjena (Solanum Melongena L.); sólo produce pérdidas económicas significativas en el tomate (Gleason y col. 1991). También afecta malezas de la familia de las solanáceas como $S$. douglasii, S. nigrum y S. triflorum (Bradbury, 1986). Otras malezas, como Datura stramonium, Chenopodium álbum y Amaranthus retroflexus son posibles reservorios de inóculo (Chang y col. 1992).

\section{Fuentes de inóculo primario y secundario}

En muchas ocasiones, el inicio de esta enfermedad o infección primaria se produce a partir de semillas infectadas internamente o infestadas superficialmente (Tancos y col. 2013), constituyendo la fuente de inóculo primario más importante (Chang y col. 1991; de León y col. 2011); puede transmitirse así a grandes distancias. La tasa de semillas contaminadas que pueden llegar a causar una epidemia en condiciones adecuadas es baja, entre el 0,01 al $0,05 \%$ (Chang y col. 1991). Los plantines con infecciones latentes también pueden ser una fuente de inóculo importante cuyos síntomas se manifiestan a medida que avanza el cultivo (Ricker y Riedel 1993; Werner y col. 2002). La multiplicación y dispersión bacteriana se ven favorecidas por el ambiente cálido y húmedo del invernadero durante la producción de los mismos (Hausbeck y col. 2000).

Por otra parte, el patógeno puede sobrevivir en restos de plantas enfermas, tallos y raíces. En cultivos de campo de otros países, la bacteria fue detectada en rastrojos entre tres semanas y más de 24 meses de finalizado el cultivo, según la zona geográfica, el tipo y ubicación de los restos en el suelo (Gleason y col. 1991; Fatmi y Shaad 2002). En invernaderos del CHP no superaría los 10 meses (Vega y col. 2010). La supervivencia del patógeno estaría relacionada con parámetros de descomposición del rastrojo (Vega y col. 2011b). Si bien la introducción del patógeno a un lote sano ocurre a través de las semillas, una vez instalado puede sobrevivir en rastrojos y ser éstos la fuente de inóculo primario más importante. En estudios realizados en cultivos enfermos a lo largo de varios años en las 
islas Canarias se encontró un solo haplotipo de Cmm (de León y col. 2011), lo mismo ocurrió en Serbia y en Japón donde determinaron que independientemente del lugar y del híbrido analizado, en un invernadero siempre se encontraron los mismos haplotipos a lo largo de los años, lo que indicaría una fuente de inóculo local, en oposición a un reingreso en semillas todos los años (Kawaguchi y col. 2010; Kawaguchi y col. 2014).

La bacteria también puede sobrevivir en malezas, bandejas de siembra, herramientas y tutores de madera que se reciclan para la campaña siguiente (Blanchard 1996; Jones y col. 2001).

La diseminación de la bacteria de plantas enfermas a las sanas puede ocurrir por el contacto directo entre las plantas o a través de las herramientas de trabajo y las manos de los operarios durante las prácticas culturales como el desbrote, deshoje o tutorado. El ingreso a las plantas puede ocurrir a través de aberturas naturales como estomas, hidátodos o flores; heridas superficiales, como tricomas rotos; o bien por heridas que llegan al tejido vascular, como las que se producen en el momento de las labores culturales (Gleason y col. 1993; Sillón 1997; Carlton y col. 1998; EPPO 2013). En este caso se transmite al resto de las plantas en la hilera del cultivo (Figura 1) (Kawaguchi y col. 2010). También se observó que las bacterias pueden propagarse en la línea del cultivo a partir de los fluídos que se producen durante la gutación, incluso de plantas asintomáticas (Sharabani y col. 2013).

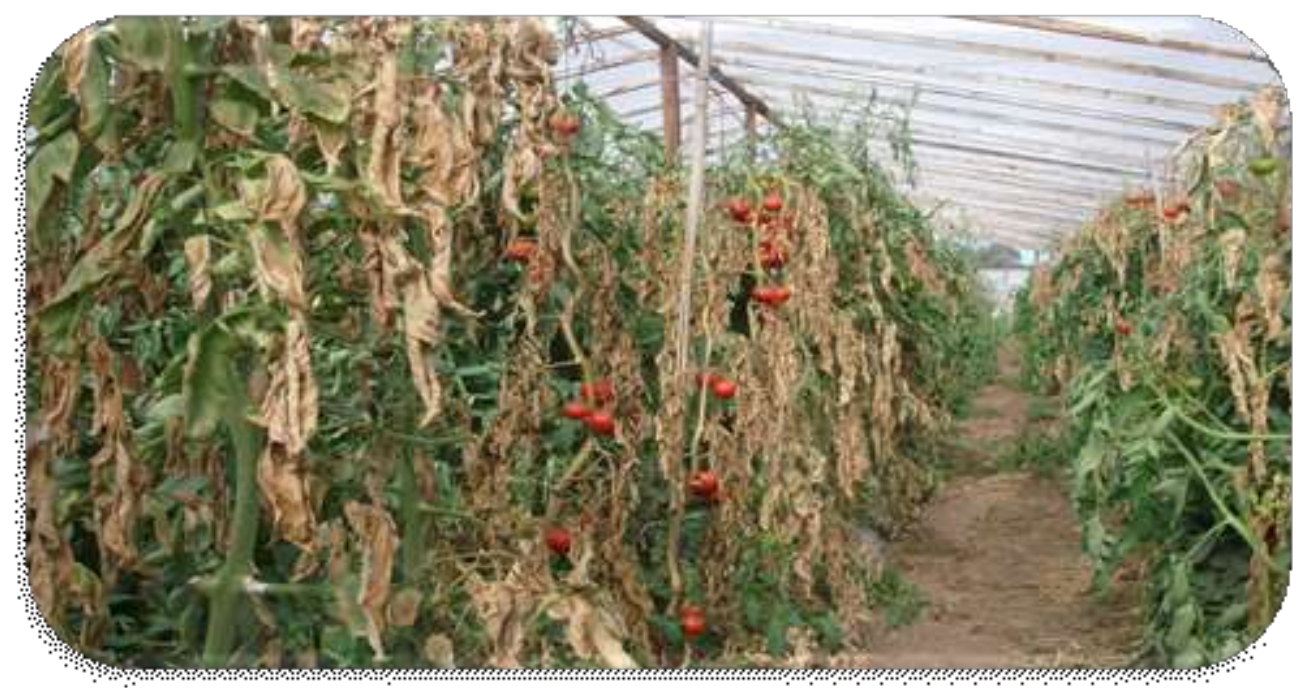

Figura 1: Diseminación de la enfermedad en la hilera del cultivo a través de las herramientas de trabajo que ocasionan el marchitamiento y muerte de las plantas (cultivo de tomate bajo cubierta en el CHP). 


\section{Descripción de los síntomas}

La gran variedad de síntomas causados por $\mathrm{Cmm}$ puede diferenciarse en función de si desarrollan infecciones sistémicas o localizadas. Si las infecciones se producen a partir del inóculo portado por la semilla o a través de heridas directamente en el tejido vascular, se observan los síntomas de las infecciones sistémicas. Si lo hace por heridas superficiales, como tricomas rotos, o aberturas naturales, como estomas o hidatodos, pueden aparecer primero los síntomas de infección localizada (Gleason y col. 1993; Carlton y col. 1998; EPPO 2013).

En la infección localizada se produce una necrosis en los folíolos de aspecto seco y color marrón claro, generalmente en el margen de la hoja que se curva hacia abajo; a veces aparece un halo amarillo entre la zona afectada y el tejido verde (Figura 2). Ocasionalmente el margen necrótico se ensancha y puede llegar a causar marchitamiento de folíolos y hojas. En los frutos los síntomas consisten en lesiones pequeñas (menos de 0,3 $\mathrm{cm}$ de diámetro), de color bronceado con halos blancos, llamadas manchas en "ojo de pájaro", este síntoma puede permanecer como una infección superficial o bien invadir el xilema y alojarse en la semilla (Figura 4) (Gleason y col. 1993; Poissenier y Rat 1993; EPPO 2013; Tancos 2013). En la infección sistémica, el síntoma principal es el marchitamiento. Frecuentemente, en una etapa temprana en algunas hojas se observan zonas de un color verde-opaco y de aspecto húmedo o graso entre las nervaduras, que luego se secan. A medida que avanza la enfermedad, los folíolos a lo largo de un lado de una hoja se vuelven flácidos, perdiendo turgencia, mientras que el resto de la planta mantiene un aspecto sano; los productores denominan a este síntoma "hoja de trapo" (Figura 3). Los folíolos pueden marchitarse unilateralmente, lo que termina en la muerte de la hoja. El tejido vascular de los tallos infectados muestra una coloración amarillenta que luego cambia al marrón, especialmente en los nudos del tallo. La médula y el tejido vascular pueden tener aspecto harinoso. En los tallos y pecíolos, bajo ciertas condiciones de temperatura y humedad se forman los cancros de color marrón (Figura 4). En los frutos, los tejidos vasculares que se encuentran por debajo de la cicatriz del cáliz y las que conducen a las semillas pueden observarse de color amarillo oscuro a marrón (Gleason y col. 1993; Seebold 2008; EPPO 2013). 
Si bien el tomate puede ser atacado desde el estado de plantín hasta planta adulta, generalmente los síntomas causados por $\mathrm{Cmm}$ no se expresan en las plantas jóvenes (EPPO 2013), mientras que en las plantas injertadas, cuando las infecciones fueron ocasionadas por el uso de cuchillas contaminadas, puede ocurrir el marchitamiento temprano (Xu y col. 2012).
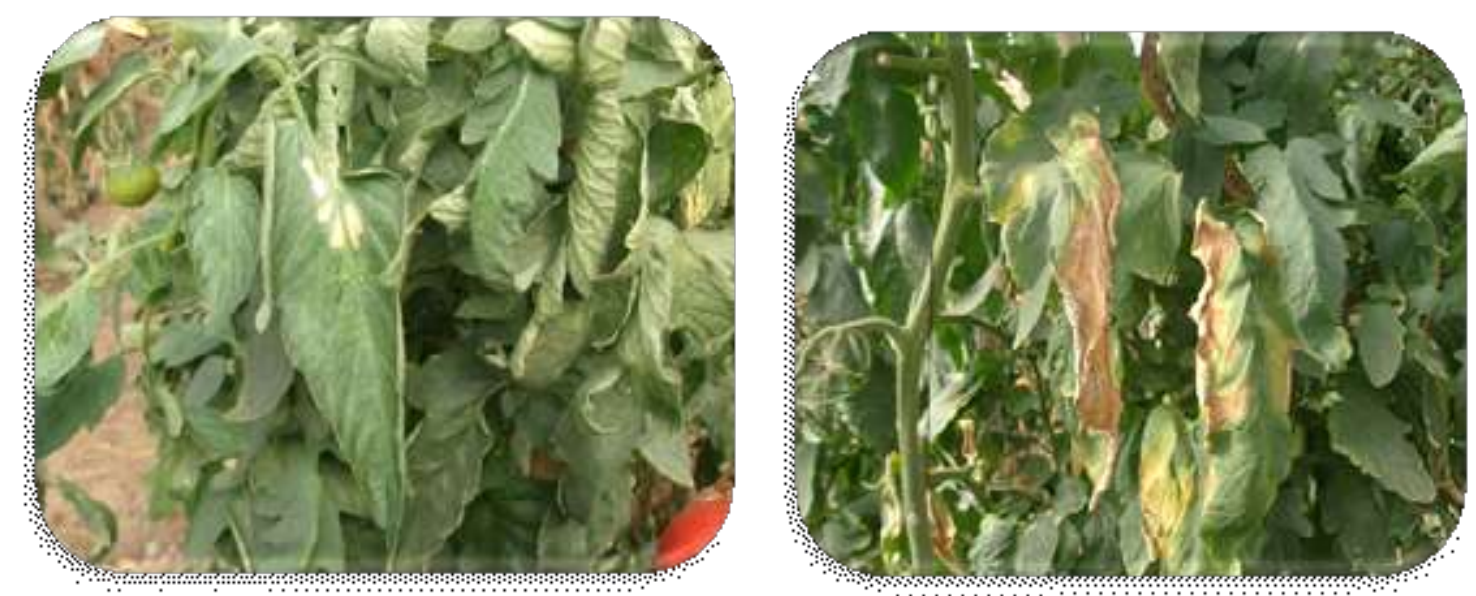

Figura 2: Síntomas locales: a la izquierda manchas necróticas internervales. A la derecha manchas necróticas marginales en los folíolos. Síntomas observados durante los muestreos en el CHP.
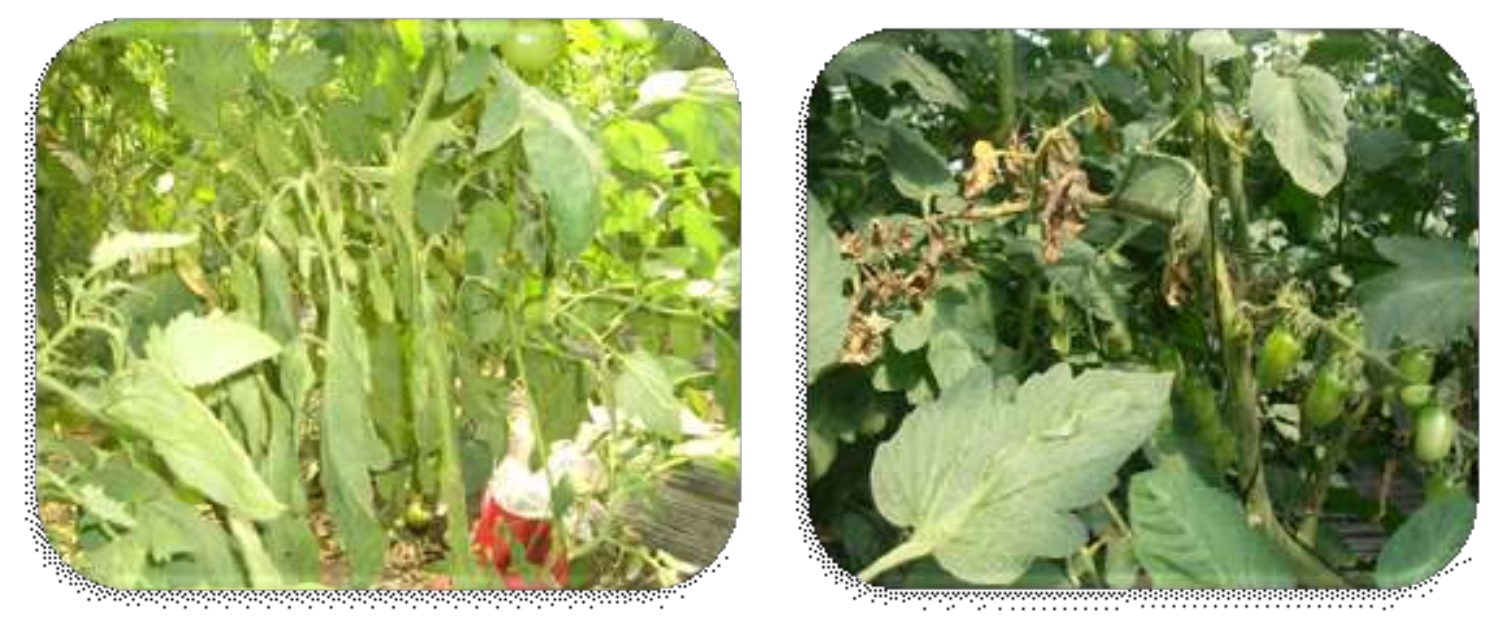

Figura 3: Síntomas sistémicos: a la izquierda folíolos que pierden turgencia por la infección vascular "hoja de trapo". A la derecha marchitamiento y necrosis unilateral de la hoja. Síntomas observados durante los muestreos en el CHP. 

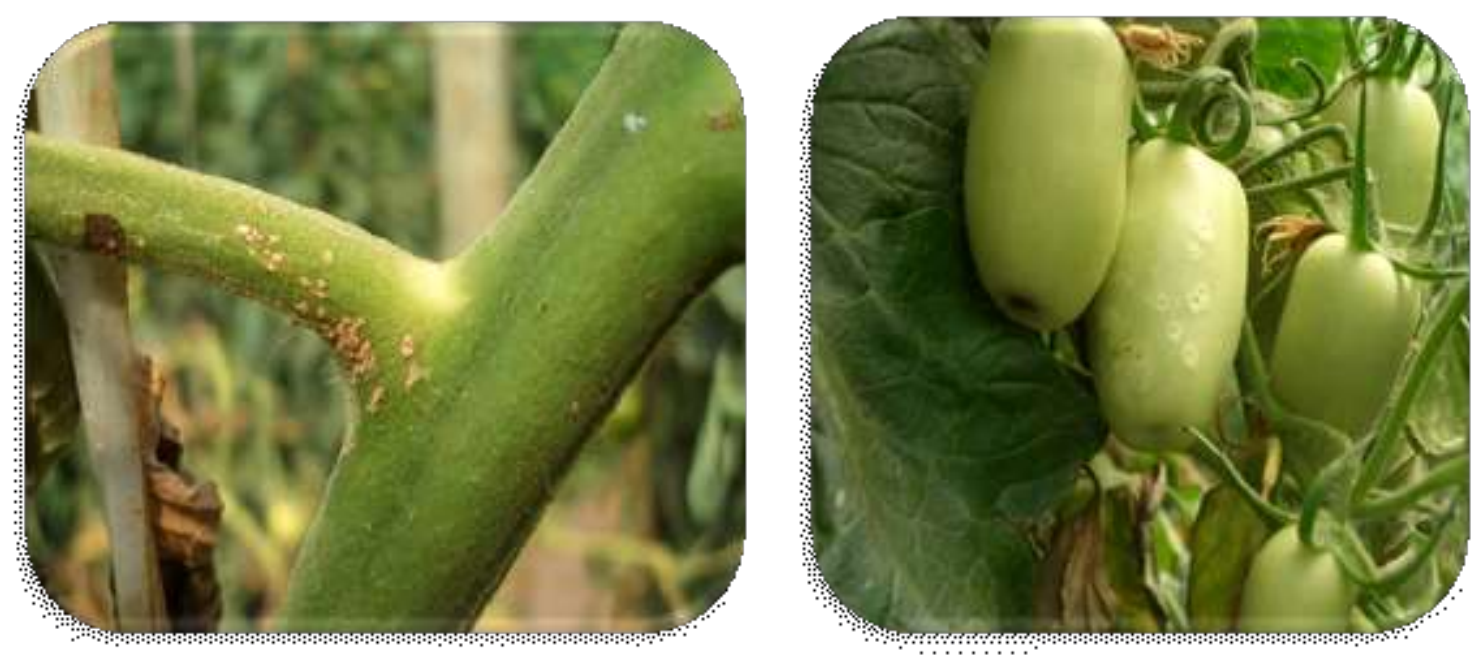

Figura 4: Síntomas en tallo y fruto. A la izquierda cancros en tallo que dan el nombre a la enfermedad. A la derecha se observan los síntomas típicos en fruto llamados "mancha en ojo de pájaro". Síntomas observados durante los muestreos en el CHP.

\section{Colonización del tejido de la planta}

Una vez dentro de los tejidos, las bacterias colonizan principalmente los vasos del xilema (Jahr y col. 1999) donde se produce una interacción con la planta en dos etapas, una endófita y otra inductora de síntomas. En la fase endófita el patógeno puede sobrevivir en el interior de los vasos de manera asintomática y cuando alcanza una población de $10^{8} \mathrm{UFC} / \mathrm{g}$ de tejido está en condiciones de inducir los síntomas de la enfermedad (Garteman y col. 2003). La transición a la segunda etapa se basa en una amplia multiplicación del patógeno en el xilema, donde las bacterias se adhieren a los engrosamientos de las paredes secundarias de los vasos. Cuando los vasos se encuentran dañados por la colonización bacteriana, éstas pueden migrar a las células parenquimáticas adyacentes (Chalupowicz y col. 2012). Cmm produce exopolisacáridos (EPS) que generan una matriz saturada de agua alrededor de las bacterias como protección contra la deshidratación (Leigh y Coplin 1992) y posiblemente impidan el reconocimiento del agente patógeno por el sistema de defensa de la planta. Además, estos compuestos de alto peso molecular junto con el título elevado de bacterias en los vasos del xilema y la acción de enzimas, especialmente pectinolíticas y celulolíticas, contribuyen a un estrés hídrico severo provocando el marchitamiento (Wallis 1977; Jahr y col 1999). La bacteria puede traslocarse en ambas direcciones dentro de la 
planta (Xu y col. 2012). El período de incubación puede extenderse entre los 7 y los 21 días. La expresión de los síntomas depende, en general, de algunos factores como las condiciones ambientales, la densidad del inóculo, la edad y el estado nutricional de la planta (Walker y Kendrick 1948; Strider 1970; Gitaitis y col. 1991; Chang y col. 1992; Sharabani y col. 2012)

\section{Manejo de la enfermedad}

El cancro bacteriano del tomate es una enfermedad de muy difícil manejo ya que las labores de desbrote y deshoje se repiten durante todo el ciclo del cultivo y las heridas que se producen constituyen la forma de penetración más efectiva de la bacteria (Rista y col. 2005 b). Cuando los brotes son más grandes a medida que avanza el ciclo del cultivo, las heridas también, y si las plantas están húmedas constituyen un mecanismo de propagación sumamente eficiente. Otro inconveniente serio para el manejo del cancro es la dificultad de su detección temprana debido a que puede permanecer latente por largos períodos (Chang y col. 1992). Por este motivo, cuando se detecta en el cultivo ya existe una epidemia en la plantación. Además, por tratarse de una enfermedad vascular, una vez que las plantas se infectan, el control químico es prácticamente imposible. Por otra parte, no existen en el mercado híbridos o cultivares con resistencia genética aceptable. El manejo debería basarse en prácticas preventivas.

Este se basa en reducir el inóculo inicial mediante el uso de semillas/ plantines libres del patógeno, junto con la rotación de cultivo, (Chang y col. 1991; de León y col. 2011). Una vez establecido el cultivo, se debería evitar la dispersión del inóculo secundario mediante la desinfección de las herramientas de desbrote, debido a que todas las prácticas que impliquen heridas incrementan la propagación del patógeno. Por lo general se recomienda el uso de hipoclorito de sodio o calcio (Kawaguchi y col. 2014), aunque este producto no parece ser totalmente efectivo para evitar la dispersión del patógeno (Rista y col. 2005 b). En un ensayo en macetas, el cloruro de benzalconio dio mejores resultados (Vega y col 2009), pero se desconoce su efectividad en cultivo. 


\section{Características de la bacteria}

El género Clavibacter pertenece al Phyllum Actinobacteria, Orden Actinomycetales, Familia Microbacteriaceae. Este género consta de una sola especie Clavibacter michiganensis que es fitopatógena y se subdivide en cinco subespecies cada una con una diferente especificidad con el hospedante: C. michiganensis subsp. sepedonicus causa la podredumbre anular de la papa; C. michiganensis subsp. insidiosus el marchitamiento de la alfafa; C. michiganensis subsp. nebraskensis, marchitamiento, mancha foliar y tizón en maiz; C. michiganensis subsp. tessellarius, mosaico bacteriano del trigo y C. michiganensis subsp. michiganensis, marchitamiento o cancro bacteriano del tomate (Eichenlaub y col. 2006; Kado 2010; CABI 2014).

Es un bacilo Gram positivo, sin flagelos, aeróbico, productor de cápsula pero no esporas, negativo para las pruebas oxidasa y ureasa. Puede ser cultivado en un medio nutritivo como el caldo nutritivo con extracto de levadura agarizado (NBY, Nutrient Broth Yeast) o el extracto de levadura con dextrosa y $\mathrm{CaCO}_{3}$ (YDC, Yeast Dextrose Carbonate) (Schaad y col. 2001), donde en 48 - 72 h forma colonias de 2-3 mm de diámetro, convexas, lisas, con borde entero, de color amarillo pálido a naranja, opaco, y mucoides, con un poco de brillo cuando son jóvenes; con el tiempo la intensidad de la pigmentación de las colonias amarillas aumenta. Los pigmentos se componen de carotenoides (Torres y col. 2003) La temperatura óptima de crecimiento in vitro es de 25 a $28^{\circ} \mathrm{C}$. En cuanto a su morfología, las células pueden aparecer individuales, pero también en forma de V o Y (Schaad y col. 2001; Jones y col. 2001).

El cromosoma de $\mathrm{Cmm}$ es una molécula de ADN circular de $3.298 \mathrm{Mb}$ y un alto contenido de $\mathrm{G}+\mathrm{C}(72,6 \%)$ (Gartemann y col. 2008). Las cepas patógenas tienen dos plásmidos circulares, pCM1 (27,4 kb; 66,5\% G+C) y pCM2 (67,6 kb; 66,5\% G+C), los que contienen genes de patogenicidad esenciales. También se identificaron aproximadamente 20 regiones con un bajo contenido de $\mathrm{G}+\mathrm{C}$ distribuidas en el cromosoma. Estas islas genómicas son específicas de $\mathrm{Cmm}$ y no están presentes en otras subespecies. La isla más grande, es la denominada $\operatorname{chp/tomA.~Se~ha~demostrado~que~esta~región~contiene~genes~}$ necesarios para la virulencia en tomate (Gartemann y col. 2008). Otra característica es la presencia de numerosos genes codificadores de al menos 28 proteasas extracelulares (serín 
proteasas) pertenecientes a tres familias diferentes. Una de ellas llamada Pat-1 pertenece a la familia Chp y es necesaria para el desarrollo de los síntomas (marchitamiento), pero no lo es para la colonización. Estas serín proteasas tienen un rol importante en la interacción planta-patógeno (Gartemann y col. 2008).

\section{Métodos de diagnóstico}

El diagnóstico de $\mathrm{Cmm}$ puede realizarse por distintos métodos: microbiológicos clásicos, serológicos y moleculares (EPPO 2013). El primero tiene la ventaja de que el equipamiento y los insumos necesarios son accesibles y de uso común en un laboratorio de diagnóstico. Además, al final del proceso se dispone de aislamientos cuya patogenicidad puede ser comprobada in vivo, y que pueden preservarse para estudios futuros (Gleason y col. 1993). La desventaja principal es el tiempo necesario para realizar las determinaciones hasta obtener el resultado, ya que requiere el aislamiento del microorganismo en medios de cultivo, seguido de la identificación a partir de característica morfológicas y reacciones fisiológicas y bioquímicas de cepas puras (EPPO 2013). Esta técnica se sigue utilizando masivamente en la actualidad.

Dentro de los métodos serológicos, los más utilizados son las técnicas inmunoenzimáticas, como el ensayo ELISA (Enzyme Linked Inmunosorbent Assay). Esta técnica se basa en el uso de antígenos o anticuerpos conjugados con una enzima. Presenta la ventaja de ser sensible, rápida y relativamente económica, además puede utilizarse para analizar un número grande de muestras, ya sea de material vegetal o colonias aisladas (Borboa Flores y col. 2009). El límite de detección es aproximadamente de $10^{3} \mathrm{UFC} / \mathrm{ml}$ (de León y col. 2007). Como desventaja se puede mencionar que el método no aporta información sobre la viabilidad del patógeno (Gleason y col. 1993). Otra técnica serológica que ha sido muy utilizada es la inmunofluorescencia (IF). Tiene un límite de detección similar a la anterior, sin embargo, ha sido ampliamente criticada ya que presenta una baja especificidad debido a la ocurrencia de reacciones cruzadas (de León y col. 2007; de León y col. 2011).

Las pruebas moleculares que se basan en la reacción en cadena de la polimerasa (PCR, Polymerase Chain Reaction), se utilizan comúnmente en la detección e identificación de los diferentes grupos de patógenos, por ser rápidos, específicos y sensibles (Ozdemir, 
2005). Una variante de la técnica tradicional es la PCR en tiempo real o cuantitativa (QPCR), este método reduce los tiempos de análisis, tiene mayor sensibilidad, disminuye el riesgo de falsos positivos y permite la cuantificación de una porción del ADN (Schaad y col. 2002). El límite de detección de Cmm por PCR es aproximadamente $2 \times 10^{2} \mathrm{UFC} / \mathrm{ml}$ (Dreier y col. 1995). La cantidad de muestra utilizada en cada reacción de amplificación es muy baja, además se han reportado compuestos derivados de las plantas que actúan como inhibidores de la PCR y pueden provocar falsos negativos (Dreier y col. 1995; Schaad y col. 2002), sin embargo se han desarrollado distintas estrategias para superar estas desventajas (Dreier y col. 1995). Lamentablemente, estas técnicas moleculares no están al alcance de todos los laboratorios de diagnóstico debido a los costos que presenta el equipamiento, como así también el grado de preparación del personal que lleva adelante las determinaciones.

\section{Panorama local}

El cancro bacteriano del tomate se encuentra presente el Cinturón Hortícola Platense aunque no hay registros que permitan cuantificar la magnitud del problema. Una vez que se presenta en un lote, el patógeno tiene una alta velocidad de transmisión principalmente durante las labores de desbrote y deshoje que se realizan en el cultivo. Es por lo tanto indispensable seleccionar, entre los desinfectantes de herramientas de corte propuestos en trabajos previos, el de mayor efectividad y que al mismo tiempo tenga baja toxicidad para el operario y el cultivo, sea económico y esté fácilmente disponible en el mercado. Además, es necesario contar con un método de diagnóstico que permita obtener resultados confiables en poco tiempo, tanto en plantas con síntomas como en aquellas asintomáticas, y que resulten una alternativa para aquellos laboratorios que no tengan los medios necesarios para hacer un diagnóstico por PCR. 


\section{OBJETIVO GENERAL}

El objetivo de este trabajo fue evaluar variables que permitan mejorar el manejo del cancro bacteriano del tomate en la zona del Cinturón Hortícola Platense, con el enfoque en los siguientes factores: la cuantificación de la presencia de la enfermedad en invernaderos de la zona, su detección en infecciones latentes y la prevención de la dispersión secundaria por las herramientas de trabajo.

\section{OBJETIVOS ESPECÍFICOS}

-Determinar la prevalencia e incidencia del cancro bacteriano del tomate en invernaderos comerciales en la zona del Cinturón Hortícola de La Plata.

-Establecer un método de diagnóstico confiable y rápido que permita identificar a Clavibacter michiganensis subsp. michiganensis en plantas de tomate asintomáticas en laboratorios de tecnología intermedia.

-Evaluar la efectividad de distintos desinfectantes sobre las herramientas de corte usadas en las labores de rutina del cultivo. 


\section{CAPITULO I}

Relevamiento de Campo del Cancro bacteriano del tomate en el Cinturón Hortícola Platense

\section{I.1 INTRODUCCION}

El cinturón hortícola Platense (CHP) se caracteriza por tener un esquema de producción intensivo, que actualmente se considera como el más tecnificado del país (García 2011). Dentro de las innovaciones tecnológicas incorporadas de manera creciente desde la década de 1990 se encuentra la adopción generalizada de invernaderos (CHBA 1998; Zembo 1998). Esta se asocia con una serie de ventajas en la producción con respecto a la modalidad productiva tradicional a campo, como por ejemplo la precocidad, el incremento de los rendimientos, la homogeneidad y la calidad de los productos cosechados. Sin embargo, como contrapartida, estos sistemas se han vuelto altamente dependientes de insumos externos. Asimismo, se tornaron inestables por la excesiva simplificación del agroecosistema y subestimación de los procesos naturales. Dicha fragilidad se manifiesta en resurgencias recurrentes de plagas animales y enfermedades, lo cual pone en riesgo a la producción. En este sentido, surge que los problemas sanitarios son una de las principales limitantes productivas en especies hortícolas del CHP (Amma y col. 2004).

El tomate es el principal cultivo hortícola del CHP; hay más de 3000 ha bajo cubierta donde se produce el $67 \%$ del total de la provincia de Buenos Aires (CHFBA 2005). La producción de tomate bajo invernadero si bien presenta las ventajas mencionadas anteriormente también se ha vuelto compleja debido al confinamiento del área cultivada y la continua sucesión de un mismo cultivo durante todo el año, lo que genera un ambiente favorable (microclima) para el establecimiento y desarrollo de plagas y enfermedades (García y col. 2005; Strassera 2006). Siendo las enfermedades uno de los elementos limitantes dentro de la producción, es importante el manejo que se realiza de las mismas. Sin embargo muchas veces al no tener un adecuado conocimiento del agente causal, y no saber distinguir la sintomatología que producen los diferentes patógenos, se aplican 
medidas de control inapropiadas. Por esta razón es que en el manejo de enfermedades es fundamental el correcto diagnóstico del agente causal (March y col. 2010).

En esta zona, el cancro bacteriano, causado por Clavibacter michiganensis subsp. michiganensis ( $\mathrm{Cmm}$ ), afecta seriamente los cultivos en invernadero. En relevamientos informales previos se han observado casos en donde la mayoría de las plantas estaban afectadas. La enfermedad puede producir grandes pérdidas de rendimiento varían con el año, el lugar y el estado fenológico del cultivo en el momento de la infección (Chang y col. 1992; Poysa 1993; Sen y col. 2015), y si las infecciones son sistémicas o localizadas.

Actualmente no existen híbridos comerciales con resistencia genética a $\mathrm{Cmm}$ pero hay algunas especies de tomate silvestre, especialmente las de fruto verde que son utilizadas en los planes de mejoramiento en todo el mundo (Blancard y col. 2011). Las especies que han aportado hasta ahora más genes de resistencia a las variedades cultivadas son $S$. pimpinellifolium L., S. peruvianum L. y en menor medida $S$. habrochaites S. Knapp y D.M.Spooner (syn. L. hirsutum Humb. y Bonpl.). Se trata de resistencias parciales, con niveles de expresión muy influenciados por las condiciones del medio (Francis y col. 2001; Kabelka y col. 2002; Blancard y col. 2011).

Pese a la importancia del cancro bacteriano del tomate en el CHP, se desconoce su difusión y con qué nivel afecta a los cultivos. Para conocerlos, se pueden utilizar distintos parámetros epidemiológicos (Agrios 2005). Los más utilizados son la severidad, la incidencia y la prevalencia. Tanto la incidencia como la severidad aportan información a nivel cultivo, y por lo tanto son de gran utilidad para la toma de decisiones de los productores. La incidencia se refiere a la proporción de los individuos relevados que están afectados por una enfermedad en un lote o invernadero y la severidad representa el porcentaje del tejido enfermo. En este caso, por tratarse de una enfermedad sistémica, que causa el marchitamiento y muerte de las plantas, es más útil evaluar la incidencia de la enfermedad. La prevalencia, por otro lado, se aplica en una escala mayor, ya que se refiere a la proporción de lotes o invernaderos donde la enfermedad está presente entre los relevados en una zona (Madden y col. 2007).

Para que los productores puedan implementar medidas de manejo es necesario conocer la incidencia de la enfermedad en sus establecimientos, y a nivel regional e institucional es importante conocer su prevalencia. Esta información permitirá a las asociaciones de 
productores en conjunto con los organismos del estado y privados que participan en el sector, entre otras medidas planificar e implementar las estrategias de manejo sanitario y de políticas de financiamiento focalizadas en la disminución del impacto económico de la enfermedad.

El objetivo del presente capitulo consistió en determinar la prevalencia e incidencia del cancro bacteriano del tomate en invernaderos comerciales en la zona del Cinturón Hortícola de La Plata. 


\section{I.2 MATERIALES Y METODOS}

I.2.1 Relevamiento de plantas para determinar Incidencia y Prevalencia

Entre los años 2008-2011, de manera consecutiva y en el 2014 se realizaron muestreos en invernaderos comerciales de las principales zonas productoras de tomate bajo cubierta del CHP. Se hicieron relevamientos en las localidades de Abasto, A. Echeverry, Arana, Berazategui, Colonia Urquiza, El Peligro, J. Gorina, L. Olmos y Los Hornos, pertenecientes al partido de La Plata (Fig. I.1).

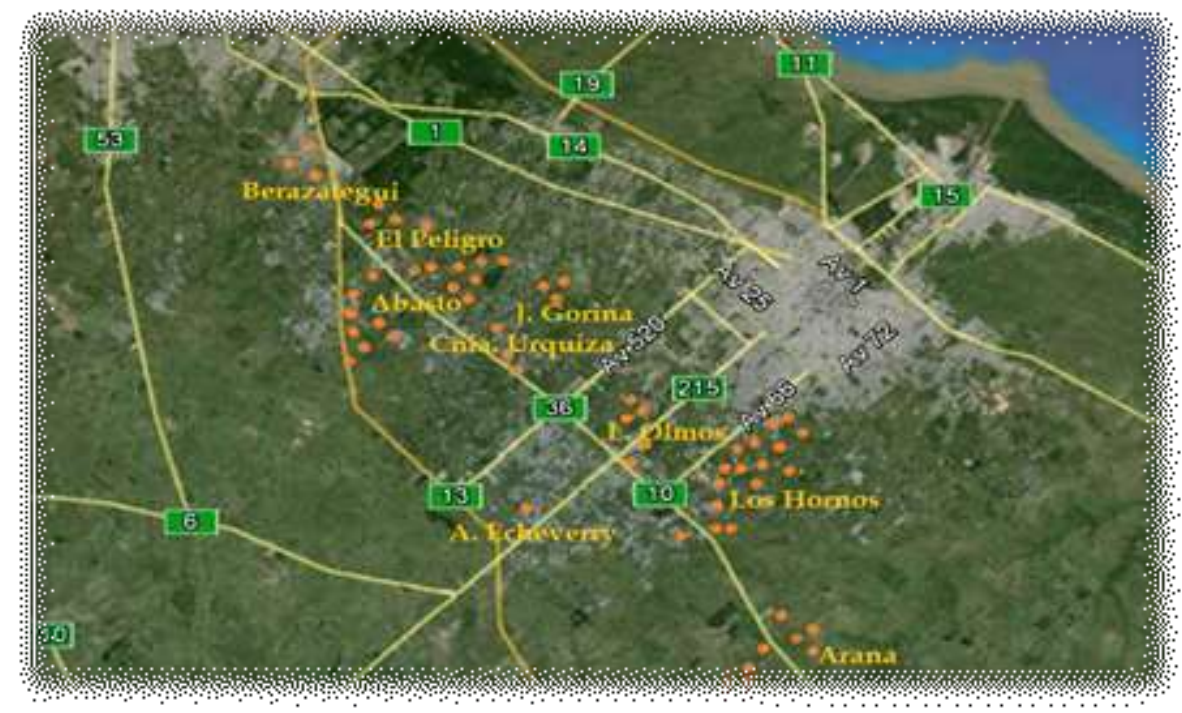

Figura I.1-Localidades muestreadas en el Cinturón Hortícola Platense, los puntos de colores representan los invernaderos visitados.

En el período 2008-2011 se visitaron entre 6 y 10 invernaderos por año y en el año 2014 se aumentó la intensidad de muestreo, incluyéndose 30 invernaderos. En cada uno se relevaron todas las plantas presentes en 40-60 m de surco lineal, dependiendo de las características de cada invernadero (aproximadamente 160-230 plantas/surco), registrándose el total de plantas y de aquellas que manifestaban síntomas de cancro bacteriano. Se evaluaron 5 surcos elegidos al azar por invernadero. Para el período 20082011 los relevamientos no coincidieron en un mismo estado fenológico del cultivo mientras que en el año 2014 se realizaron en el estado de noveno racimo en cultivos de producción 
tardía (implantados en enero), ya que es el período en el que la enfermedad se manifiesta con mayor intensidad

En cada caso, se registraron el tipo de tomate, híbrido y cultivo predecesor, y se tomaron muestras de plantas con síntomas de la enfermedad para posteriormente confirmar el diagnóstico en el laboratorio.

Los datos cuantitativos fueron analizados mediante un análisis de la varianza (ANOVA), y cuando los datos no cumplieron con los supuestos del modelo, se hizo un análisis no paramétrico (Test de Kruskall-Wallis). Para los datos cualitativos se realizó un análisis de Chi cuadrado. Se utilizó el software Infostat (Infostat 2009).

\section{I.2.2 Aislamiento e identificación del patógeno}

El diagnóstico de campo se corroboró mediante técnicas microbiológicas y moleculares en los laboratorios (EPPO 2013) del Centro de Investigaciones de Fitopatología (CIDEFI) de la Facultad de Ciencias Agrarias y Forestales (UNLP) y de la cátedra de Fitopatología de la Facultad de Agronomía de la UBA, respectivamente.

Los aislamientos se realizaron a partir de tejido infectado de tallos y folíolos. Las muestras, porciones de tallos de $2 \mathrm{~cm}$ y trocitos de folíolos de $1 \mathrm{~cm}$ aproximadamente, se lavaron con agua de canilla durante 2 a 3 min, luego se desinfectaron con alcohol $70 \%$ y con hipoclorito de sodio al 0,5\% durante 1 min y se enjuagaron con agua destilada estéril. Las muestras desinfectadas se dilaceraron y se colocaron en tubos de ensayo individuales con 5 $\mathrm{ml}$ de agua destilada estéril durante $15 \mathrm{~min}$. La suspensión obtenida se sembró en forma de estrías en placas con un medio de cultivo general, agar caldo nutritivo-extracto de levadura (NBY) (Gross y Vidaver 1979; Schaad y col. 2001). Las placas fueron incubadas en estufa a $27^{\circ} \mathrm{C}$ y observadas a las $48-72 \mathrm{~h}$.

Los aislamientos se identificaron mediante la tinción de Gram, la forma de las células y las características morfológicas de las colonias, como su color, forma, tamaño, altura y borde (Schaad y col. 2001). Los aislamientos se verificaron en forma rápida mediante la reacción de hipersensibilidad en plantas de "Diego de noche" (Mirabilis jalapa L.), mantenidas en invernadero. La suspensión bacteriana se preparó a partir de colonias cultivadas en medio NBY a $27^{\circ} \mathrm{C}$ durante $48-72 \mathrm{~h}$. Las plantas, de 20-25 cm de altura y con 4-6 hojas, se 
infiltraron en los espacios intercelulares de las hojas con una suspensión de $5 \times 10^{8} \mathrm{UFC} / \mathrm{ml}$ con una jeringa de $1 \mathrm{ml}$ (Gleason y col. 1993; Alarcón y col. 1998). Se utilizó agua estéril como control negativo. La reacción se observó a las 24- 48 h, como una necrosis en la zona infiltrada.

La identificación del patógeno se confirmó mediante la técnica de amplificación por la reacción en cadena de la polimerasa (Polymerase Chain Reaction, PCR) utilizando los primers CMM5 (GCG AAT AAG CCC ATA TCA A) y CMM6 (CGT CAG GAG GTC GCT AAT A), específicos para este patógeno por ser derivados del gen de patogenicidad pat-1 presente en el plásmido pCM2 (Dreier y col. 1995), y los primers PSA-4 (TCA TTG GTC AAT TCT GTC TCC C) y PSA-R (TAC TGA GAT GTT TCA CTT CCC C) correspondientes a la región intergénica 16S-23S del rARN (Patrik y Rainey 1999). En ambos casos la amplificación se realizó con GoTaq ${ }^{\circledR}$ DNA Polymerase (Promega) según el protocolo del fabricante, con $20 \mathrm{pmol}$ de cada primer y $50 \mathrm{ng}$ de templado. Las condiciones de amplificación para los primers PSA-4/PSA-R fueron: desnaturalización inicial a $94{ }^{\circ} \mathrm{C}$ durante 2,5 min, seguido de 40 ciclos con 3 segmentos: $94{ }^{\circ} \mathrm{C}$ por $30 \mathrm{~s}$, hibridación a $63{ }^{\circ} \mathrm{C}$ por $20 \mathrm{~s}$, y una extensión de $72{ }^{\circ} \mathrm{C}$ durante $45 \mathrm{~s}$; la polimerización final se realizó a $72{ }^{\circ} \mathrm{C}$ por $5 \mathrm{~min}$. Las condiciones de amplificación del gen pat- 1 fueron: $10 \mathrm{~min}$ a $94{ }^{\circ} \mathrm{C}$, seguido de 35 ciclos de $90 \mathrm{~s}$ a $94{ }^{\circ} \mathrm{C}, 2 \min$ a $55^{\circ} \mathrm{C}$ y $2 \min$ a $72{ }^{\circ} \mathrm{C}$; y una extensión final de 10 min a $72^{\circ} \mathrm{C}$. Los productos de reacción se separaron mediante electroforesis horizontal en geles de agarosa al 1,2\% en buffer TBE 0,5 a $90 \mathrm{~V}$ por $3 \mathrm{~h}$. Los geles se tiñeron con SybrSafe (Invitrogen).

La patogenicidad de las cepas identificadas positivamente se verificó en plantines de tomate del híbrido Elpida (Syngenta) de $20 \mathrm{~cm}$ de altura y 4 hojas desplegadas. La inoculación se realizó siguiendo la técnica descripta por Schaad y col. (2001); brevemente, se cortó una hoja a la altura de la base del pecíolo con un bisturí sumergido en una suspensión bacteriana. Las plantas testigo se trataron igual, utilizándose agua destilada estéril en lugar de inóculo. Se observaron los plantines hasta la aparición de los síntomas.

Para su conservación por periodos de tiempo cortos, las cepas puras se mantuvieron en heladera a $4^{\circ} \mathrm{C}$, en tubos con medio NBY. Para su preservación prolongada se mantuvieron en caldo nutritivo con $20 \%$ de glicerol a $-80{ }^{\circ} \mathrm{C}$ (Schaad y col. 2001). 


\section{I.3 RESULTADOS}

I.3.1 Relevamiento en invernaderos

En los muestreos realizados en el período 2008-2011 y en el 2014, el cancro bacteriano fue detectado en las nueve localidades de mayor importancia en la producción de tomate del CHP.

Se observaron dos tipos de manchas en las hojas, unas necróticas internervales, y con menor frecuencia marginales, con aspecto desecado, coloración marrón clara y de diversos tamaños, en algunos se unían resquebrajando la hoja y plegando los folíolos hacia abajo. El otro tipo corresponde a las infecciones sistémicas y eran manchas acuosas o grasientas entre las nervaduras dónde los folíolos pierden la turgencia conocida como "hoja de trapo" permaneciendo el resto de la planta verde. En la planta entera, el síntoma predominante fue el marchitamiento generalizado tanto en planta verde como en estados más avanzados, en aquellas con clorosis generalizada. En el interior de los tallos los vasos presentaron distintas coloraciones desde amarillentas a marrón y en estados avanzados de la enfermedad también la médula se vio desintegrada de color marrón o blanco harinosa. En los tallos se observaron cancros pero con baja frecuencia. En los frutos, principalmente en el tipo perita ubicado en los bordes del invernadero, se observaron pequeñas manchas necróticas con halo blanco.

El síntoma que se observó predominando en todos los invernaderos muestreados fue el de tipo sistémico, manifestándose como un marchitamiento generalizado que comienza con la pérdida de turgencia de algunas hojas y culmina con la muerte de la planta.

\section{I.3.2 Período 2008-2011}

En los muestreos realizados entre el 2008 y el 2011 la enfermedad fue detectada en las ocho localidades relevadas. El porcentaje de invernaderos afectados, es decir la prevalencia de la enfermedad, promedio del período fue del $80 \%$, con un mínimo de $67 \%$ en 2011 y un máximo de $100 \%$ en 2008 (Cuadros I.1 y I.2). 
CuadroI.1: Incidencia del cancro bacteriano en plantas de tomate en relevamientos realizados en el Cinturón Hortícola Platense, según localidad, híbrido de tomate y cultivo antecesor en el período 2008-2011.

\begin{tabular}{|c|c|c|c|c|}
\hline Año & Localidad & Híbrido & Antecesor & $\begin{array}{c}\text { Incidencia } \\
\%\end{array}$ \\
\hline 2008 & El Peligro & Elpida & tomate & 60 \\
\hline 2008 & El Peligro & Griffit & tomate & 100 \\
\hline 2008 & El Peligro & Silverio & tomate & 100 \\
\hline 2008 & El Peligro & Eco (perita) & tomate & 33 \\
\hline 2008 & Abasto & Badro & tomate & 17 \\
\hline 2008 & Abasto & Chareston & tomate & 13 \\
\hline 2008 & Los Hornos & Superman & hoja & 40 \\
\hline 2008 & Los Hornos & Superman & hoja & 20 \\
\hline 2009 & Abasto & Elpida & tomate & 10 \\
\hline 2009 & L. Olmos & Zorzal (perita) & descanso & 0 \\
\hline 2009 & Abasto & Elpida & tomate & 14 \\
\hline 2009 & Abasto & Elpida & tomate & 38 \\
\hline 2009 & Arana & Griffit & descanso & 33 \\
\hline 2009 & Arana & Eco (perita) & tomate & 20 \\
\hline 2010 & Arana & Elpida & tomate & 80 \\
\hline 2010 & Arana & Eco (perita) & Hoja & 40 \\
\hline 2010 & Abasto & Elpida & Tomate & 50 \\
\hline 2010 & J. Gorina & Elpida & Descanso & 25 \\
\hline 2010 & A.Echeverry & Elpida & Tomate & 30 \\
\hline 2010 & Los Hornos & Elpida & Hoja & 20 \\
\hline 2010 & Los Hornos & Elpida & Tomate & 0 \\
\hline 2010 & Berazategui & Elpida & Descanso & 0 \\
\hline 2010 & Berazategui & Elpida & Tomate & 29 \\
\hline 2010 & Berazategui & Elpida & Tomate & 0 \\
\hline 2011 & Los Hornos & Elpida & Hoja & 0 \\
\hline 2011 & Los Hornos & Elpida & Tomate & 40 \\
\hline 2011 & Los Hornos & Elpida & Tomate & 20 \\
\hline 2011 & Los Hornos & Griffit & Descanso & 33 \\
\hline 2011 & L. Olmos & Elpida & Apio & 0 \\
\hline 2011 & L. Olmos & Elpida & Hoja & 33 \\
\hline
\end{tabular}


En promedio, la incidencia de plantas afectadas por cancro fue del 29,9 \%. El mínimo se registró en el año 2009 y el máximo en el 2008 (Cuadro I.2). En este último año hubo dos invernaderos con valores de incidencia del $100 \%$ (Cuadro I.1). Los valores de la incidencia condicional, es decir considerando solo los invernaderos donde la enfermedad fue detectada (Madden y col. 2007), fueron ligeramente superiores. La incidencia condicional promedio fue del 37,4 \%, con valores entre 23 y $48 \%$ (Cuadro I.2).

Cuadro I.2: Frecuencia de invernaderos afectados con el cancro bacteriano del tomate por año y localidad e incidencia promedio de plantas enfermas por año.

\begin{tabular}{llllll}
\hline Localidad & $\mathbf{2 0 0 8}$ & $\mathbf{2 0 0 9}$ & $\mathbf{2 0 1 0}$ & $\mathbf{2 0 1 1}$ & $\mathbf{2 0 1 4}$ \\
\hline Abasto & $2 / 2$ & $3 / 3$ & $1 / 1$ & & $10 / 10$ \\
Arana & & $2 / 2$ & $2 / 2$ & & $5 / 5$ \\
A. Echeverry & & & $1 / 1$ & & \\
Berazategui & & & $1 / 3$ & & \\
Cnia. Urquiza & & & & & $2 / 3$ \\
J. Gorina & & & $1 / 1$ & & $2 / 2$ \\
L. Olmos & & $0 / 1$ & & $1 / 2$ & $2 / 2$ \\
Los Hornos & $2 / 2$ & & $1 / 2$ & $3 / 4$ & $7 / 8$ \\
El Peligro & $4 / 4$ & & & & \\
N & 8 & 6 & 10 & 6 & 30 \\
Prevalencia (\%) & 100 & 83,3 & 70 & 67 & 93,3 \\
Incidencia (\%) & 48 & 19 & 27 & 21 & 15,4 \\
$\begin{array}{l}\text { Incidencia } \\
\text { condicional (\%) }\end{array}$ & 48 & 23 & 39 & 31,5 & 16,5 \\
\hline
\end{tabular}


E1 $61 \%$ de los invernaderos muestreados habían tenido tomate como cultivo antecesor, el $23 \%$ provenían de cultivos de hoja o apio, y el $16 \%$ restante había tenido descanso (Cuadro I. 1). Hubo una tendencia de los invernaderos provenientes de descanso a tener una prevalencia de cancro menor que con los otros antecesores, aunque no fue significativa $\left(\mathrm{X}^{2}\right.$; $\mathrm{p}<0,05)$ (Cuadro I.3). La misma tendencia, no significativa, se observó en la incidencia de plantas enfermas (ANOVA; $\mathrm{p}=0,3239$ ).

Cuadro I.3: Prevalencia e incidencia promedio del cancro bacteriano en invernaderos del CHP según cultivo antecesor; años 2008-2011.

\begin{tabular}{lccc}
\hline \multicolumn{1}{c}{ Antecesor } & $\mathbf{N}$ & $\begin{array}{c}\text { Prevalencia } \\
(\mathbf{\%})\end{array}$ & $\begin{array}{c}\text { Incidencia } \\
\mathbf{( \% )}\end{array}$ \\
\hline Monocultivo (Tomate) & 18 & 89 & 36 \\
Otros Cultivos & 7 & 71 & 21 \\
Descanso & 5 & 60 & 18 \\
\hline
\end{tabular}

En este período se hicieron dos tipos de tomate, redondo (87\%) y perita (13\%). Si bien se plantaron seis genotipos de tomate redondo diferentes, el $69 \%$ de los casos correspondió a un solo híbrido, Elpida. El cancro fue detectado en el $75 \%$ de los invernaderos de perita y en el $80 \%$ del redondo Todos los genotipos de tomate redondo incluidos en el estudio fueron susceptibles al cancro bacteriano (Cuadro I.1). 


\section{I.3.3 Campaña 2013- 2014}

El cancro bacteriano fue detectado en las seis localidades donde se hicieron muestreos en el año 2014. La prevalencia de invernaderos afectados fue del $93 \%$ (Cuadros I. 4 y I.5).

Cuadro I.4: Incidencia del cancro bacteriano en plantas de tomate en relevamientos realizados en el Cinturón Hortícola Platense, según localidad, híbrido de tomate y cultivo antecesor en el año 2014.

\begin{tabular}{|c|c|c|c|c|}
\hline 2014 & Localidad & Hibrido $^{1}$ & Antecesor & Incidencia (\%) \\
\hline 1 & Los Hornos & Rocco (cherry) & Tomate & 5 \\
\hline 2 & Los Hornos & Elpida & Tomate & 0 \\
\hline 3 & Los Hornos & Elpida & Tomate & 12,8 \\
\hline 4 & Los Hornos & Elpida & Tomate & 5,7 \\
\hline 5 & Los Hornos & Yígido 7742 & Tomate & 9,8 \\
\hline 6 & Los Hornos & Elpida & Tomate & 2 \\
\hline 7 & Los Hornos & Elpida & Tomate & 11,2 \\
\hline 8 & Los Hornos & Santa Paula (perita) & Tomate & 16,9 \\
\hline 9 & Abasto & Elpida & tomate & 100 \\
\hline 10 & Abasto & Elpida & tomate & 71 \\
\hline 11 & Abasto & Kogi (cherry) & Tomate & 8,3 \\
\hline 12 & Abasto & Smartii (cherry) & Hoja & 3,6 \\
\hline 13 & Abasto & Elpida & hoja y berenjena & 3,7 \\
\hline 14 & Abasto & Kogi (cherry) & Hoja & 14,8 \\
\hline 15 & Abasto & Platense & Descanso & 1,7 \\
\hline 16 & Abasto & Yígido 7742 & Tomate & 20 \\
\hline 17 & Abasto & Elpida & Pepino & 49 \\
\hline 18 & Abasto & Elpida & Tomate & 18,1 \\
\hline 19 & Arana & Elpida & Tomate & 19,7 \\
\hline 20 & Arana & Torry & Tomate & 11,2 \\
\hline 21 & Arana & Yígido 7742 & Tomate & 6,9 \\
\hline 22 & Arana & TL Capicua & Tomate & 4,4 \\
\hline 23 & Arana & Elpida & Tomate & 19,4 \\
\hline 24 & J. Gorina & Elpida & Tomate & 11,1 \\
\hline 25 & J. Gorina & Santa Paula (perita) & Tomate & 13,4 \\
\hline 26 & Cnia. Urquiza & Smartii (cherry) & Descanso & 0 \\
\hline 27 & Cnia. Urquiza & Elpida & Tomate & 3,8 \\
\hline 28 & Cnia. Urquiza & Elpida & Tomate & 5,5 \\
\hline 29 & L. Olmos & Elpida & Tomate & 5,4 \\
\hline 30 & L. Olmos & Elpida & Tomate & 6,2 \\
\hline
\end{tabular}

${ }^{\mathrm{I}}$ Todos los genotipos corresponden a híbridos de tomate redondo, excepto cuando se indica. 
La incidencia promedio de plantas enfermas fue del 15,4\%, con valores que oscilaron entre el 0 y el 100 \% (Cuadros I.2 y I.4). Los valores más altos correspondieron a la localidad de Abasto, donde se registró un valor promedio de $29 \%$, y la más baja a Colonia Urquiza con un promedio de 3,1 \% (Cuadro I.5). Las diferencias entre localidades no fueron significativas (Kruskal-Wallis, $\mathrm{H}=5,575 ; \mathrm{p}=0,3497$ ). La incidencia condicional promedio fue del 16,5\% (Cuadro I.2).

Cuadro I.5: Prevalencia e Incidencia promedio del cancro bacteriano en invernaderos del CHP por localidad en el año 2014.

\begin{tabular}{lcc}
\hline Localidad & $\begin{array}{c}\text { Prevalencia } \\
(\%)\end{array}$ & $\begin{array}{c}\text { Incidencia } \\
\text { promedio } \\
(\%)\end{array}$ \\
\hline Abasto & 100 & 29 \\
Arana & 100 & 12 \\
Cnia. Urquiza & 66,6 & 3,1 \\
J. Gorina & 100 & 12 \\
Los Hornos & 87,5 & 7,9 \\
L. Olmos & 100 & 5,8 \\
Total & $\mathbf{9 3}$ & $\mathbf{1 5 , 4}$ \\
\hline
\end{tabular}

E1 $80 \%$ de los invernaderos muestreados tuvieron como antecesor cultivos de tomate, el $13,4 \%$ habían sido destinados a otros cultivos y el 6,6 \% restante venían de descanso (Cuadro I.4). Cuando el lote provenía de descanso la prevalencia y la incidencia promedio fueron menores que cuando el antecesor había sido tomate u otro cultivo. La diferencia en la incidencia entre antecesores no fue significativa (Kruskal-Wallis, $\mathrm{H}=1,38 ; \mathrm{p}=0,5016$; Cuadro I.6). Como el número de lotes con descanso había sido muy bajo en el 2014, no se analizó la prevalencia para ese año. Cuando se calculó en conjunto para los períodos 20082011 y 2014, fue significativamente diferente según antecesores $\left(X^{2} ; p=0,05\right)$. 
Cuadro I.6: Prevalencia e Incidencia promedio del cancro bacteriano del tomate en invernaderos del CHP según el cultivo antecesor, año 2014.

\begin{tabular}{lccc}
\hline Antecesor & $\mathbf{N}$ & $\begin{array}{c}\text { Prevalencia } \\
(\mathbf{\%})\end{array}$ & $\begin{array}{c}\text { Incidencia } \\
\mathbf{( \% )}\end{array}$ \\
\hline Tomate & 24 & 96 & 16,1 \\
Otros Cultivos & 4 & 100 & 17,7 \\
Descanso & 2 & 50 & 0,85 \\
\hline
\end{tabular}

El tipo comercial de tomate más usado en los invernaderos muestreados correspondió a tomate redondo (77\%), seguido por cherry (S. lycopersicum var. ceraciforme (Dunal) (17 $\%)$ y perita (6\%). Todos los genotipos plantados fueron susceptibles al cancro bacteriano (Cuadro I.4). Entre los tomates tipo redondo, el híbrido Elpida fue el más plantado (74\%) y también fue el de mayor incidencia de plantas enfermas: $21,5 \%$ vs $9 \%$ promedio del resto de los tomates redondos. Los invernaderos plantados con tomate tipo cherry registraron los menores valores de prevalencia e incidencia (Cuadro I.7).

Cuadro I.7: Prevalencia e Incidencia promedio del cancro bacteriano del tomate en invernaderos del CHP según el tipo comercial de tomate.

\begin{tabular}{lccc}
\hline Tipo Comercial & N & $\begin{array}{c}\text { Prevalencia } \\
(\mathbf{\%})\end{array}$ & $\begin{array}{c}\text { Incidencia } \\
\mathbf{( \% )}\end{array}$ \\
\hline Redondo & 23 & 95 & 17,7 \\
Perita & 2 & 100 & 15,1 \\
Cherry & 5 & 80 & 6,3 \\
\hline
\end{tabular}

\section{I.3.4 Identificación en laboratorio}

C. michiganensis subsp. michiganensis fue identificada en el $97 \%$ de las muestras de plantas diagnosticadas en el campo como afectadas por el cancro bacteriano. Las colonias presentaron las siguientes características morfológicas y culturales: forma circular, con elevación convexa, borde entero, pequeñas, mucosas, opacas y color amarillo pálido a anaranjado; la tinción de las células fue color azul púrpura, que responde a bacterias Gram positivas, la mayor cantidad dispuestos de a pares y en forma de V, que coincide con la descripción de Schaad y col. (2001). La reacción de hipersensibilidad en Mirabilis jalapa L. fue positiva. Las amplificaciones realizadas por PCR generaron bandas de los tamaños 
esperados, $614 \mathrm{pb}$ para la fracción del gen pat-1 amplificada con los primers CMM5 y CMM6, y 270 pb para la región amplificada con los primers PSA-4 y PSA-R, confirmando que los aislamientos obtenidos de plantas enfermas correspondían a C. michiganensis subsp. michiganensis (Figura I.2).

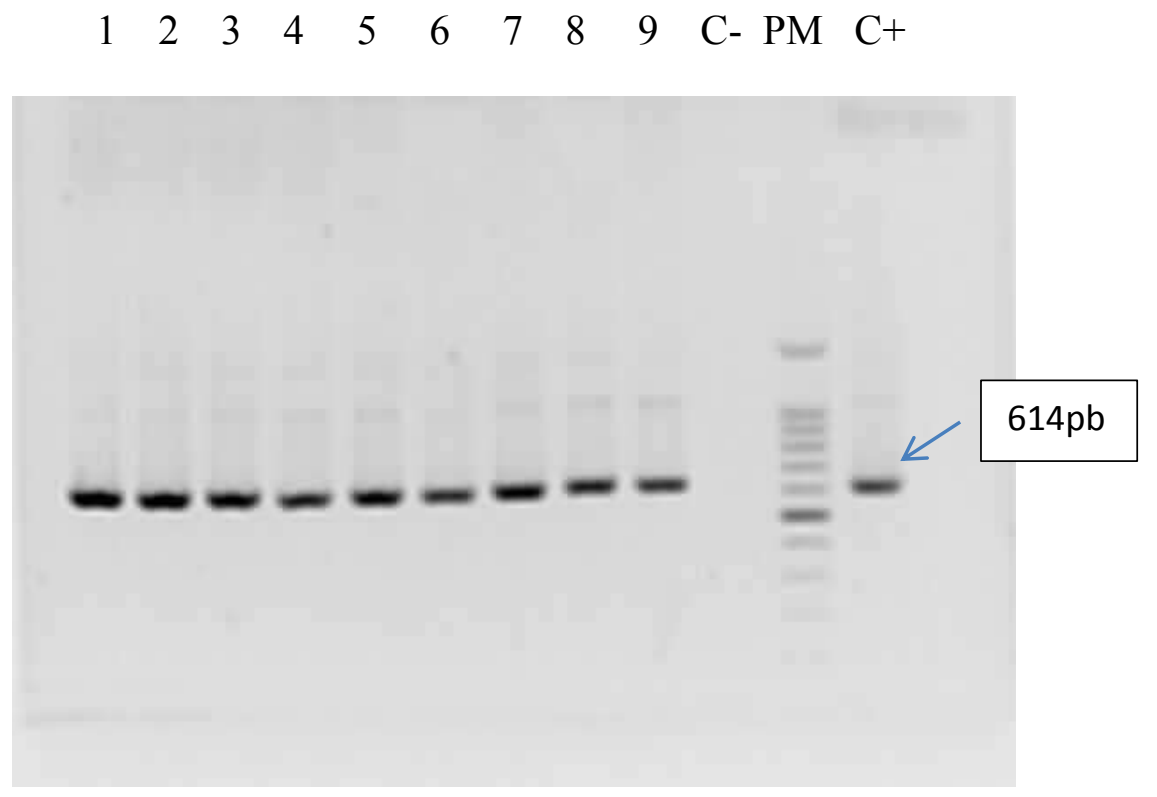

Figura I. 2: Detección de Clavibacter michiganensis subsp. michiganensis a partir de cultivo bacteriano. De izquierda a derecha muestras 1 a 9, Control negativo, Ladder y Control positivo. Las bandas amplificadas corresponden a la fracción del gen pat-1 de $614 \mathrm{pb}$.

La prueba de patogenicidad en plantines de tomate permitió completar la identificación. Todas las cepas inoculadas presentaron los síntomas típicos de marchitamiento, que comenzaron a registrarse a partir de los 20 días posteriores a la inoculación. En un comienzo los síntomas se presentaron próximos a la zona de inoculación y a medida que transcurrieron los días se fueron generalizando en toda la planta. Las plantas utilizadas como controles negativos no presentaron síntomas. 


\section{I.4 DISCUSION}

Los diversos síntomas observados en hojas, tallos y frutos, tanto locales como sistémicos, principalmente el marchitamiento generalizado en pocas plantas o abarcando hileras completas coinciden con los descriptos para Cmm (Gleason y col. 1993; Poissenier y Rat 1993; Carlton y col. 1998; EPPO 2013; Tancos 2013). Un pequeño porcentaje de plantas con síntomas similares no dieron resultados positivos en las pruebas microbiológicas, por lo cual se considera que el diagnóstico a partir de los síntomas exclusivamente no es suficiente, sino que es necesario realizar las pruebas de laboratorio correspondientes. Los síntomas que produce la bacteria $\mathrm{Cmm}$ pueden confundirse con los causados por otros patógenos vasculares de origen bacteriano y fúngico (Blancard, 1996; Alippi y col. 2003; EPPO/ CABI 2005; Janse, 2006; Alippi y López 2010; March y col. 2010).

Cmm está ampliamente difundida en el CHP. Fue detectada afectando cultivos de tomate en invernaderos de todas las localidades relevadas, desde el año 2008. Los niveles de incidencia promedio de plantas enfermas variaron con los años, entre 16 y 48 \% (llegando a $100 \%$ en casos individuales), posiblemente debido a diferentes condiciones ambientales que resultaron más o menos predisponentes para el cancro bacteriano.

Los períodos de descanso entre cultivos resultaron ser sumamente beneficiosos para reducir la aparición de la enfermedad, tal como ocurre en otros casos (García y col. 2005; Strassera 2006). En los relevamientos realizados durante los períodos 2008-2011 y 2014, en el $43 \%$ de los lotes que venían de descanso no se detectó la enfermedad, mientras que si venían de otro cultivo o de monocultivo de tomate ese número bajó a 18 y $7 \%$, respectivamente (Cuadros I.3 y I.6). Además, en los casos en los que la enfermedad fue detectada, los invernaderos que habían tenido un período de descanso entre cultivos tuvieron una tendencia a una menor incidencia del cancro bacteriano, respecto de aquellos lotes sin descanso. Posiblemente esto esté relacionado con la actividad microbiana en el suelo y la descomposición de los rastrojos infestados. Cmm puede sobrevivir durante dos a 10 meses en invernaderos en esta zona, según la época del año y si los rastrojos están enterrados o en superficie (Vega y col. 2011b). Se ha propuesto que ésta es la principal fuente de inóculo primario en países como Japón, Israel e Islas Canarias (Kleitman y col. 2008; De León y col. 2009; Kawaguchi y col. 2010; Kawaguchi y col. 2014), donde determinaron que en un 
mismo invernadero siempre aparece el mismo haplotipo del patógeno, independientemente del año y del híbrido del que fue aislado. Apoyando esta hipótesis, en Abasto, Arana, J. Gorina y Lisandro Olmos, hubo invernaderos que fueron muestreados en distintos años: una vez que el patógeno fue detectado en un invernadero, siguió siéndolo en años posteriores. Sin embargo, esta situación no se repitió en todos los casos, ya que en uno de los invernaderos que habían tenido cancro bacteriano en Los Hornos en 2008 no volvió a detectarse en los muestreos de 2010, 2011 y 2014. Para poder determinar si los rastrojos son la principal fuente de inóculo en el CHP, tal como ocurre en otros lugares, sería conveniente profundizar en los estudios relacionados con la diversidad poblacional de Cmm.

En relación al tipo de tomate los muestreos incluyeron nueve hibridos y una variedad (platense) de tomate redondo y todos fueron susceptibles al cancro; lo mismo se observó en el tipo perita, aunque con menos genotipos evaluados. Esto era esperable ya que no hay materiales con resistencia genética importante a esta enfermedad. Por otro lado, durante el periodo evaluado hubo una tendencia a reducir el número de genotipos plantados, especialmente entre los tomates de tipo redondo. El híbrido Elpida que en el año 2008 representaba el 14 \% de los híbridos de tipo redondo, pasó a 75 \% en 2009, 100 \% en 2010, $83 \%$ en 2011 y $74 \%$ en 2014. Este híbrido, además, es el que presentó los mayores niveles de incidencia de cancro bacteriano. En el último año evaluado se incorporaron algunos otros híbridos del tipo redondo, además de aumentar la proporción de los tipos perita y cherry. En este trabajo, los híbridos del tipo cherry tuvieron una tendencia a presentar una incidencia menor de plantas con cancro bacteriano que los tipos redondo y perita, Esto coincide con lo observado por Romero y col. (2003), quienes observaron que las plantas de tomate redondo inoculadas con $\mathrm{Cmm}$ fueron más susceptibles y murieron anticipadamente respecto a las de tomate cherry. Estos valores inferiores de incidencia en el tomate cherry también podrían deberse a cierta resistencia morfológica. Sen y col. (2015) describieron que Solanum habrochaites y tomates tipo cherry presentan haces vasculares de mayor tamaño, con sus paredes más gruesas y el crecimiento vascular es más rápido respecto a otros tipos comerciales. Estas características podrían jugar un papel en la resistencia a las enzimas producidas por el patógeno en la degradación de las paredes celulares, y por lo 
tanto las diferencias morfológicas entre especies silvestres resistentes de tomate y cultivares comerciales podrían estar involucradas en la resistencia bacteriana (Sen y col 2015).

\section{I.5 CONCLUSIONES}

El cancro bacteriano del tomate es una enfermedad prevalente en la zona del Cinturón Hortícola Platense, con una alta incidencia en los invernaderos donde se presenta, cuyo nivel varía según años.

El síntoma del cancro bacteriano del tomate que se encuentra con mayor frecuencia en los invernaderos del CHP es de tipo sistémico: un marchitamiento generalizado ya sea en plantas verdes o cloróticas, que generalmente termina con la muerte. Con menor frecuencia también se presentan síntomas de tipos locales: manchas necróticas en hojas, ramas y frutos.

La observación de los síntomas a campo no es suficiente para diagnosticar la enfermedad, es necesario recurrir a pruebas de laboratorio.

Los tomates de tipo redondo y perita que se realizan en el CHP son todos susceptibles al cancro, mientras que en el tipo cherry los niveles de enfermedad son menores.

El período de descanso entre cultivos disminuye la incidencia de la enfermedad. 


\section{CAPITULO II}

Detección de Clavibacter michiganensis subsp. michiganensis en plantas de tomate con infecciones latentes.

\section{1 INTRODUCCION}

La observación de síntomas a campo es una de las prácticas tradicionales para determinar la presencia de una enfermedad en un cultivo. Sin embargo, el marchitamiento que ocasiona el cancro bacteriano del tomate, causado por Clavibacter michiganensis subsp. michiganensis (Cmm), puede parecerse al causado por otros patógenos vasculares como por ejemplo: el marchitamiento del tomate causado por la bacteria Ralstonia solanacearum $(=$ Burkholderia solanaceraum $=$ Pseudomonas solanacearum $)$ o los de origen fúngico producidos por Fusarium oxysporum f. sp. lycopersici y Verticillium spp. (Blancard, 1996; EPPO/ CABI 2005; Janse, 2006). También se pueden confundir con los síntomas producidos por otras bacterias patógenas entre las que se incluyen Pseudomonas corrugata, $P$. mediterránea y $P$. viridiflava que si bien no causan marchitamiento vascular producen la necrosis de la médula del tallo en tomate (Alippi y col. 2003; Alippi y López 2010).

Por otra parte, la enfermedad tiene un periodo de incubación largo; tanto los plantines en el momento del trasplante como las plantas durante el cultivo pueden estar infectadas, sin manifestar síntomas. La dinámica poblacional de $\mathrm{Cmm}$ demuestra que las prácticas culturales como el desbrote y deshoje que se realizan en los lotes comerciales de tomate contribuyen a la diseminación del patógeno, estas prácticas comienzan desde las etapas tempranas del cultivo cuando la bacteria generalmente se encuentra en estado latente (Chang y col., 1991; Gitaitis y col. 1991). Sin embargo, la edad de la planta en el momento en que se produce el ingreso de la bacteria parece tener un rol fundamental en la posterior manifestación de los síntomas ya que en las plantas jóvenes los síntomas de Cmm aparecen más precozmente que en las plantas de mayor edad (Chang y col. 1992). Las plantas inoculadas después de las 17-18 hojas, si bien expresan síntomas de pérdida de turgencia en algunos foliolos, no se marchitan ni mueren (Sharabani y col. 2013), dificultando la 
detección de la enfermedad e incrementando, inadvertidamente, el inóculo en los rastrojos para el ciclo siguiente. Sharabani y col. (2013) proponen que existiría una "ventana de susceptibilidad" entre el trasplante y el estado de 17-18 hojas durante el cual la aplicación de medidas preventivas permitirían evitar la propagación secundaria de Cmm, lo que tendría un efecto durante todo el ciclo de cultivo, minimizando las pérdidas por rendimiento y la mortalidad de plantas.

Por estas razones, entre otras, es importante contar con un método de diagnóstico que sea preciso y permita detectar las infecciones tempranas, en lo posible antes de que se manifiesten los síntomas, y así poder implementar medidas de manejo que contribuyan a disminuir el impacto de la enfermedad.

Actualmente, el diagnóstico de $\mathrm{Cmm}$ en plantas de tomate se puede realizar por diversas técnicas microbiológico/bioquímicas, serológicas y moleculares, que se diferencian por complejidad, sensibilidad, necesidad de equipamiento, formación del personal técnico y tiempo en obtener los resultados (Gleason y col. 1993; Barnes 1994; de León y col. 2011; EPPO 2013; Sen y col. 2015).

Las técnicas microbiológicas implican el aislamiento del patógeno en cultivos puros y su posterior identificación según sus características fisiológicas y bioquímicas, aunque también pueden aplicarse técnicas serológicas o moleculares. $\mathrm{Cmm}$ puede crecer en diferentes medios de cultivo ya sea generales, como el YDC (Yeast Dextrose Carbonate) o el NBY (Nutrient Broth Yeast), o semiselectivos como el SCM, mSCM, CMM1 y BCT (Gross y Vidaver 1979; Schaad y col. 2000; Ftayeh y col. 2011). La eficacia del método depende de las poblaciones microbianas presentes, ya que en algunos casos el crecimiento de las colonias de Clavibacter se puede inhibir por la presencia de otros microorganismos saprófitos (Ftayeh y col. 2011; Zaluga y col. 2013). Para la identificación en diagnósticos de rutina suele ser suficiente la observación de las características morfológicas de las colonias puras, reacción a la tinción de Gram, y la forma y disposición de las células (EPPO 2013). Luego se confirman los aislamientos mediante infiltraciones en una planta indicadora (Mirabilis jalapa L.) o directamente se verifica la patogenicidad en plantines de tomate; la primera opción es más rápida ( $\sim 48$ h) que la segunda ( $\sim 3$ semanas). En algunos casos en que se requiere mayor rigurosidad o que los resultados no sean concluyentes, puede ser necesario realizar otras pruebas bioquímicas o fisiológicas, como determinar el 
metabolismo oxidativo de la glucosa, la reacción de oxidasa, hidrólisis de la esculina, uso de fuentes de carbono como acetato de sodio y succinato de sodio, crecimiento en presencia de $6 \%$ de $\mathrm{NaCl}$, entre otros (EPPO 2013). Este método no requiere equipamiento costoso, es fácil de realizar y permite almacenar el cultivo vivo, sin embargo presenta la desventaja de ser lento y laborioso, ya que requiere de varios días de trabajo hasta obtener el resultado definitivo, particularmente cuando es necesario realizar otras pruebas bioquímicas o fisiológicas, además de las de rutina. En la mayoría de los casos ese tiempo supera a la necesidad en la respuesta al productor (Gitaitis y col. 1991; Sen y col. 2015).

Las técnicas inmunológicas, comúnmente llamadas serológicas, se pueden aplicar tanto a partir de cultivos puros como de tejidos de plantas enfermas. Una de las de mayor aplicación es la inmunoenzimática ELISA (Enzyme Linked Immunosorbent Assay), en especial el método directo de doble anticuerpo (Double Antibody Sandwich, DAS- ELISA). Se basa en el uso de antígenos o anticuerpos marcados con una enzima, de tal forma que los conjugados resultantes tienen actividad tanto inmunológica como enzimática. Uno de los componentes está inmovilizado sobre un soporte; la reacción se revela mediante el agregado de un sustrato específico que produce un color observable a simple vista o cuantificable con un espectrofotómetro (Sánchez-Vizcaíno y Cambra 1981). Es un procedimiento sensible, que permite detectar títulos bajos del patógeno, preciso porque los antisueros son específicos para cada patógeno y rápido ya que los resultados se pueden obtener dentro de las 24 horas. Es muy útil cuando se deben analizar gran número de muestras en corto tiempo, evitando la etapa de aislamiento y cultivo de la bacteria (Gitaitis y col. 1991; Gleason y col. 1991; Holt y col. 1994; Gorris y col. 1996). Es una técnica simple y puede ser ejecutada por cualquier persona después de un entrenamiento no muy prolongado (Garnsey y Cambra 1991). Tiene la limitación de que no da información sobre la viabilidad del patógeno, y al finalizar el diagnóstico no se dispone de un aislamiento para probar su patogenicidad o preservarlo para estudios futuros. Además los antisueros pueden presentar baja especificidad y reconocer tanto a la bacteria buscada como a otras de la flora saprófita (Gitaitis y col. 1991; Gorris y col. 1996; Sen y col. 2015). En el caso de utilizar kits comerciales, los proveedores brindan información sobre la calidad y especificidad del antisuero, incluyendo además los testigos positivo y negativo adecuados. La empresa Agdia Inc. produce dos tipos de kits comerciales para la detección de Cmm, el SRA 44000 
constituido por antisuero policlonal y el BRA 44001 monoclonal. La empresa no informa sobre posibles reacciones cruzadas para el kit el SRA 44000, mientras que con el kit BRA 44001 pueden ocurrir reacciones cruzadas con Cm subsp. nebraskensis y con Xanthomonas campestris pv. campestris. El primero causa el tizón de la hoja y marchitamiento bacteriano del maíz; este patógeno no está citado en Argentina y no se lo ha encontrado en plantas de tomate (EPPO Global Database 2015), mientras que el segundo tampoco es patógeno del tomate.

El diagnóstico de fitopatógenos a partir de pruebas moleculares que se basan en la reacción en cadena de la polimerasa (PCR, Polymerase Chain Reaction), es rápido, específico y sensible (Ozdemir, 2005). Al igual que las técnicas serológicas, para muchas bacterias patógenas de plantas, se puede realizar directamente a partir del tejido vegetal sin necesidad de tener aislamientos puros. Sin embargo, para $\mathrm{Cmm}$ se han reportado compuestos derivados de los tejidos vegetales que pueden actuar como inhibidores de la reacción provocando falsos negativos (Dreier y col. 1995; Schaad y col. 2000; EPPO 2013), por esta razón si se realiza la prueba por este método y diera negativo, el resultado debería confirmarse realizando aislamientos (EPPO 2013). Estas técnicas requieren de equipos que aún resultan costosos, no disponibles en laboratorios de tecnología intermedia, además de personal entrenado.

La posibilidad de detectar de manera rápida y confiable la presencia de $\mathrm{Cmm}$ en las infecciones tempranas en los lotes productivos en el CHP, permitiría anticiparse en la implementación de las medidas de manejo sanitario adecuadas a las posibilidades de los productores que tiendan a reducir la propagación de la enfermedad en el cultivo y minimizando las pérdidas económicas que pudiera ocasionar.

El objetivo del presente capítulo consistió en establecer un método de diagnóstico confiable y rápido que permita identificar a Clavibacter michiganensis subsp. michiganensis en plantas de tomate asintomáticas en laboratorios de tecnología intermedia. 


\section{2 MATERIALES Y METODOS}

Se comparó la sensibilidad de dos métodos de laboratorio para la detección de $\mathrm{Cmm}$ en plantas de tomate infectados, antes y después de que manifestaran síntomas de cancro bacteriano: convencional, que consistió en realizar el aislamiento, purificación e identificación de la bacteria con técnicas microbiológicas y bioquímicas vs. serológico a partir de tejido vegetal sin aislamiento del patógeno.

II. 2.1 Cultivo e inoculación de plantas

El ensayo se realizó con plantas de tomate del híbrido AIDA (NiritSeeds), en el invernadero del CIDEFI en la Facultad de Ciencias Agrarias y Forestales. Las plantas se mantuvieron en macetas de cuatro litros, una por maceta, con un sustrato mezcla compuesto por fibras de turba de musgo Sphagnum, corteza y perlita (GROW MIX Master, Terrafertil, Moreno-Argentina).

La inoculación se realizó cuando las plantas tenían una altura promedio de $27 \mathrm{~cm}$ y 9 hojas desarrolladas, colocando $50 \mu \mathrm{l}$ de una suspensión bacteriana en la axila de la $5^{\circ}$ hoja y pinchando el tallo con una aguja estéril a través de la gota. Se utilizó el aislamiento (LPAb12), de la colección creada durante este trabajo y obtenida en la campaña 2012-2013. La bacteria se mantuvo conservada por un corto período en agua mineral marca Glaciar estéril a $4{ }^{\circ} \mathrm{C}$ y fue cultivada en medio de cultivo NBY (Gross y Vidaver 1979; Schaad y col. 2000) a $27{ }^{\circ} \mathrm{C}$ durante $48 \mathrm{~h}$. Luego se suspendieron colonias puras en agua destilada

estéril, ajustándose a una lectura en el espectrofotómetro de $\mathrm{OD}_{600}=0,3\left(\sim 5,5 \mathrm{x} 10^{8}\right.$ $\mathrm{UFC} / \mathrm{ml}$ ) diluyéndose 1:10 para alcanzar la concentración de uso. Se inocularon 20 plantas con la suspensión bacteriana y 10 testigos se trataron de igual manera pero con agua destilada estéril.

Las muestras se tomaron a los 7, 14, 21 y 28 días post-inoculación, las que consistieron en dos folíolos por planta de las hojas $\mathrm{n}^{\circ} 5$ y 7 . Las muestras se tomaron por duplicado para analizar una con el método convencional y otra con el análisis serológico. 
II. 2. 2 Aislamiento e identificación del patógeno por técnicas convencionales

La forma de aislamiento y el medio de cultivo a utilizar se determinaron en un ensayo preliminar dónde se evaluaron tres métodos, a partir de porciones de tallos y hojas: 1) suspensión en agua destilada estéril (Schaad y col. 2001), 2) maceración en morteros de porcelana con agua destilada estéril y 3) improntas directas de corte transversal de tallo sobre medio de cultivo (Gitaitis y col.1991). También se evaluaron cuatro medios de cultivo, dos generales agar nutritivo (AN), y nutrient broth yeast extract agar (NBY) (EPPO 2005; Borboa, Flores y col. 2009; Yim y col. 2012), y dos semiselectivos, uno sin antibióticos yeast dextrosa carbonate (YDC) y otro con antibióticos Cicloheximida Medium Selective (CMS) (Shaad y col. 2001; Kleitman y col. 2008; Flores col. 2011). En este ensayo preliminar el método de aislamiento que resultó más apropiado es la suspensión en agua estéril y el NBY el medio de cultivo más conveniente para realizar los aislamientos. Se pudieron realizar los aislamientos e identificación en un período de tiempo comprendido entre las 48-72hs, con baja a nula contaminación, permitiendo reconocer macroscópicamente las colonias de la bacteria patógena. Los componentes del medio de cultivo no presentan riesgos extras de contaminación o toxicidad durante su manipulación.

Los folíolos se desinfectaron durante 1 minuto con hipoclorito de sodio al $0,5 \%$ y se enjuagaron en agua destilada estéril durante 3 a 5 minutos. Una vez desinfectado, se cortó el material en trocitos de $1 \mathrm{~cm}^{2}$ aproximadamente, se dilaceró y se colocó en tubos tipo Eppendorf con agua destilada estéril durante $15 \mathrm{~min}$, para facilitar la salida del flujo bacteriano (Goszczynska y col. 2000). Las suspensiones obtenidas se sembraron en placas de Petri con medio de cultivo NBY, las que se incubaron en estufa a $27^{\circ} \mathrm{C}$ por un período de 48 a 72 h.

Luego de la incubación se seleccionaron las colonias por color, forma, relieve y tipo de borde, según la descripción de Schaad y col. (2001). Las colonias seleccionadas se repicaron en medio NBY dos veces para obtener cultivos puros, los que se usaron para realizar las pruebas de solubilidad en KOH $3 \%$ (Gregersen 1978), reacción de Gram, metabolismo oxidativo-fermentativo (Hugh y Leifson 1953), oxidasa (Goszczynska, y col. 
2000) y reacción de hipersensibilidad en Mirabilis jalapa L. (Gleason y col. 1993; Alarcón y col. 1998).

La prueba de solubilidad en $\mathrm{KOH} 3 \%$ consiste en colocar una gota de este compuesto en un portaobjeto sobre la que se agrega una anzada de la colonia pura a evaluar. La bacteria es Gram (+) cuando al levantar el anza desde la gota no se forma un hilo viscoso debido a la resistencia de las paredes celulares de las bacterias a la acción del hidróxido. Si las bacterias son Gram (-), se forma el hilo viscoso debido a la degradación de las paredes.

Para la comprobación del metabolismo oxidativo de la glucosa se realizó la prueba descripta por Hugh y Leifson (1953). Cada aislamiento se sembró por punción en un medio base estéril con un indicador de $\mathrm{pH}$, en dos tubos de ensayo, luego en un tubo se adicionó vaselina estéril para crear condiciones de anaerobiosis y ambos se incubaron a $27^{\circ} \mathrm{C}$. Las bacterias que tienen metabolismo oxidativo producen un cambio de color del azul al amarillo a partir de los 5 días en el tubo que no tiene vaselina.

La prueba de oxidasa se realizó colocando colonias bacterianas sobre papel de filtro humedecido con dicloro-tetra metil-para-fenilendiamina al $1 \%$. Si las colonias se tornan púrpura entre los 30 a 60 segundos, la reacción se considera positiva.

Para la reacción de hipersensibilidad se utilizaron plantines de Mirabilis jalapa "maravilla o Don Diego de noche", obtenidas a partir de esquejes enraizados en sustrato de tierra mezclado con perlita en macetas de $14 \mathrm{~cm}$ de diámetro, cultivados y mantenidos en invernadero. Los plantines se inocularon por infiltración con jeringa en los espacios internervales, localizando la suspensión en el parénquima en empalizada. Se inocularon dos hojas por planta. Se observó el desarrollo de la reacción de hipersensibilidad a las 24-48 h. El control negativo consistió en la infiltración de agua, y el positivo una suspensión de la cepa LPAb12, usada para inocular las plantas de tomate.

\section{2. 3 Serología}

Para la detección de $\mathrm{Cmm}$ en muestras de hojas de tomate según el método DAS-ELISA, se utilizó el kit comercial SRA 44000 Reagent Set (AGDIA Inc. Elkhart, IN), siguiendo el protocolo del fabricante. 
La prueba se realizó sobre microplacas de poliestireno de 96 celdillas (Deltalab). Se utilizó el anticuerpo de captura policlonal (CAB 44000) a una concentración de 1:200. El anticuerpo fue diluido en el tampón carbonato de pegado. Cada celdilla se completó con $100 \mu \mathrm{l}$ de la solución, incubándose la placa en cámara húmeda por 4 horas a temperatura ambiente. Luego del período de incubación se realizaron los lavados de la siguiente manera: se volcó el contenido de la misma en una pileta y se agregó el tampón de lavado (PBST 1X), completando toda la placa. Luego la placa se vació, sacudiéndola enérgicamente en la pileta. Este procedimiento se repitió dos veces.

Las muestras de folíolos de hojas de tomate recolectadas del invernadero se colocaron en bolsitas de polietileno de $12 \mathrm{~cm}$ x $12 \mathrm{~cm}$, en cada una se agregó $1 \mathrm{ml}$ de tampón general de extracción (GEB) y se maceraron en una relación 1:10 (1 ml de tampón con $10 \mathrm{~g}$ de tejido). Durante este proceso las muestras se mantuvieron refrigeradas. El tampón general de extracción GEB y los controles positivo (LPC 44000) y negativo (LNC 44000/TOMATO LF), ambos constituidos por bacterias liofilizadas que se rehidrataron, fueron provistos por el fabricante, en los tres casos se sembraron por duplicado y $100 \mu 1$ por pocillo. La placa se incubó en cámara húmeda en heladera a $4{ }^{\circ} \mathrm{C}$ durante toda la noche. Luego del período de incubación se retiró la muestra de la cámara húmeda, se volcó su contenido en una pileta de lavado cuidando de no mezclar sus contenidos y se lavó como en el primer lavado, repitiendo el procedimiento 7 veces.

Para la detección se utilizó el anticuerpo policlonal conjugado a la enzima fosfatasa alcalina (ECA44000) a una concentración de 1:200. El anticuerpo fue diluido en el buffer ECI. Cada celdilla de la placa se completó con $100 \mu$ de la solución. La placa se incubó en cámara húmeda durante $2 \mathrm{~h}$ a temperatura ambiente. El lavado se realizó de la misma manera que en el paso anterior, repitiendo el procedimiento 8 veces.

La última etapa consistió en el agregado del sustrato paranitrofenilfosfato (PNP). Cada tableta de PNP (ACC 00404) de $5 \mathrm{mg}$ fue disuelta en $5 \mathrm{ml}$ de solución de PNP (1 mg/ml) (PNP solución tampón). Esta solución se preparó pocos minutos antes de finalizar el período de incubación de la etapa anterior. Se colocaron $100 \mu 1$ de la solución de PNP sustrato en cada celdilla. Se incubó la placa en cámara húmeda, a temperatura ambiente. Los resultados se evaluaron realizando lectura de la absorbancia en espectrofotómetro $\operatorname{BioRad}{ }^{\circledR}$ a $405 \mathrm{~nm}$ de longitud de onda. Las lecturas se realizaron a partir de los $20 \mathrm{~min}$. 
Se consideraron positivos los valores de absorbancia que superaban el doble del valor promedio del testigo negativo (Sutula y col. 1986; de León y col. 2008).

II. 2. 4 Análisis de los datos

Inicialmente se realizó un análisis de la varianza de los valores de absorbancia obtenidos con el método serológico, pero como los datos no cumplían el supuesto de homogeneidad de varianza, y las transformaciones realizadas no lograron mejorar la homocedasticidad, los datos se analizaron mediante ANOVA no paramétrico Kruskall- Wallis. El mismo fue realizado utilizando el software Infostat (Infostat 2009). Para los datos cualitativos se realizó un análisis de Chi cuadrado. 


\section{3 RESULTADOS}

\section{3. 1 Método convencional}

El patógeno sólo se pudo aislar a partir de los 21 días de la inoculación; este momento coincidió con la aparición de los primeros síntomas de la enfermedad.

Las características morfológicas y culturales de las colonias, y los resultados de las pruebas fisiológicas y biológicas realizadas sobre los aislamientos coincidieron en todos los casos con lo descripto por Schaad y col. (2001) para Cmm. En medio de cultivo NBY las colonias presentaron forma circular, borde entero, pequeñas, color amarillo pálido a amarillo anaranjado con elevación convexa, de consistencia mucosa. La prueba de solubilidad en $\mathrm{KOH} 3 \%$ fue negativa para $\mathrm{Cmm}$ en todos los aislamientos, y en la tinción de Gram las células se tiñeron de color azul púrpura, confirmando la presencia de una bacteria Gram (+). La mayoría de las células estaban dispuestas de a pares y en forma de V. La prueba de oxidasa fue negativa y en el test de Hugh-Leifson el metabolismo resultó aeróbico.

Dentro de las pruebas biológicas, la reacción de hipersensibilidad en Mirabilis jalapa L. fue positiva a las $48 \mathrm{~h}$ para todos los aislamientos y el control positivo. No hubo reacción con el control negativo (agua).

\section{3. 2 Método serológico}

Los datos de absorbancia se analizaron con un método no paramétrico, Kruskall- Wallis, por no cumplir el supuesto de homogeneidad de varianza que no pudo ser corregido transformando los datos. Como los resultados obtenidos coinciden con los del ANOVA paramétrico, se muestran dichos resultados. El método DAS-ELISA permitió detectar la presencia del patógeno a partir del primer muestreo. En las plantas inoculadas con la cepa LPA12 los valores de absorbancia de la hoja 5 fueron superiores al testigo en la primera evaluación, aunque luego se mantuvieron cercanos a los valores iniciales; en la hoja 7, en cambio, aumentaron a lo largo del tiempo, diferenciándose significativamente del testigo a partir de la segunda semana en adelante (ANOVA, $p=0.000018$; test de Tukey, $\alpha=0,05$; 
Figura II. 1). Un valor mayor de absorbancia se relaciona con un mayor título de la bacteria (Sánchez -Vizcaíno y Cambra 1981; López y Cambra 1996).

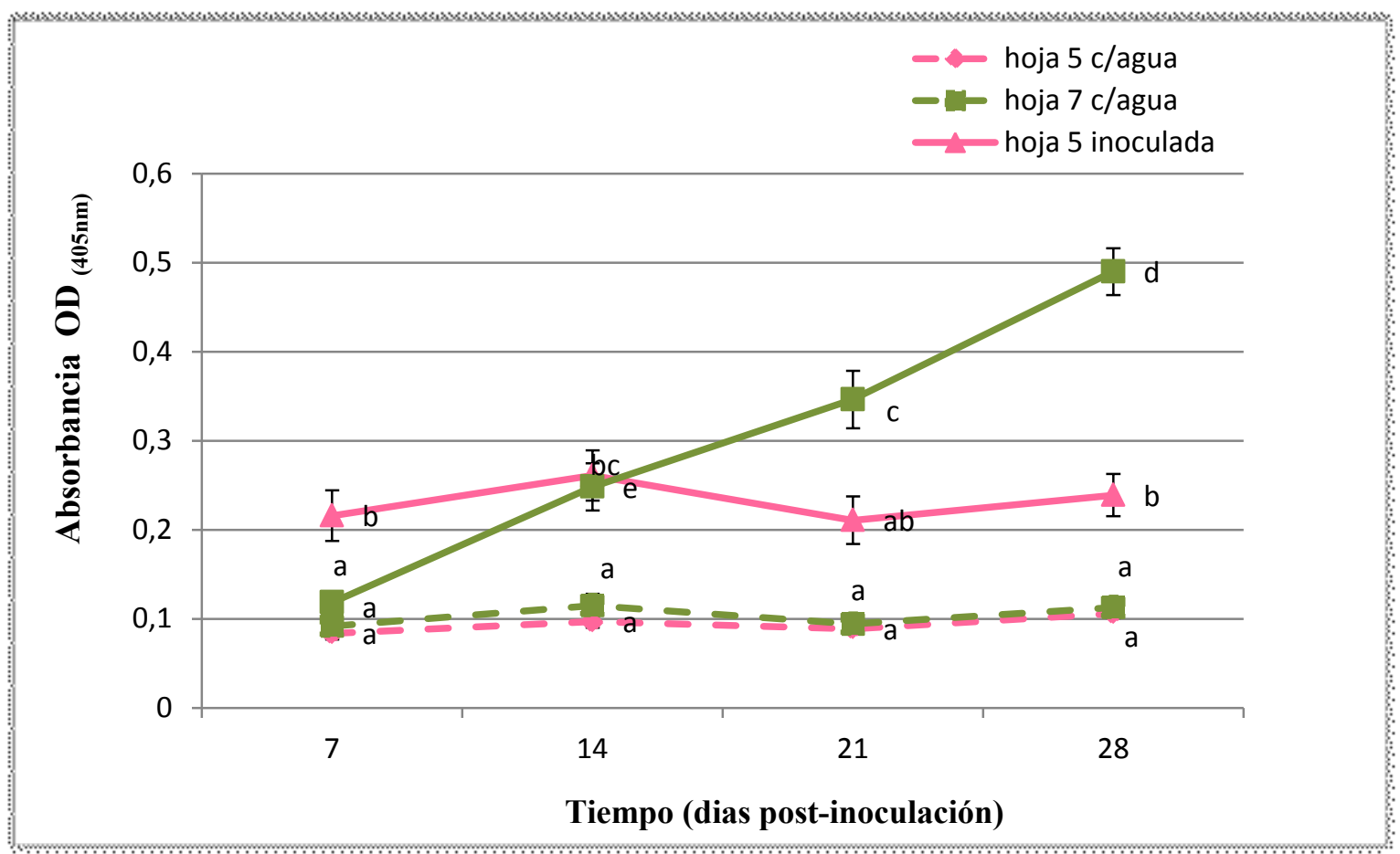

Figura II. 1: Valores de absorbancia para las hojas 5 y 7 de plantas de tomate en cuatro momentos después de la inoculación. Líneas continuas de hojas 5 y 7 corresponden a plantas inoculadas y líneas de puntos a testigo con agua. La densidad óptica fue medida a $405 \mathrm{~nm}$. Letras minúsculas diferentes sobre las curvas indican diferencias significativas $(p=0.000018$; test de Tukey, $\alpha=$ 0,05). Las barras sobre los puntos representan el error estándar

\section{3. 3 Comparación de métodos}

A los 7 y 14 días post-inoculación solo se detectó el patógeno por serología. La proporción de plantas positivas detectadas por este método continuó aumentando, resultando a los 21 y 28 días en valores significativamente mayores que los detectados por el método convencional (prueba $\mathrm{X}^{2} ; \alpha=0,05$ y 0,01, respectivamente (Figura II.2). Veintiún días después de la inoculación sólo el $25 \%$ de las plantas manifestaban síntomas de la enfermedad, sin embargo, mediante el análisis serológico se identificó el patógeno en el 70 $\%$ del total de las plantas y en el $40 \%$ fue posible aislar e identificar el patógeno por medios convencionales (Figura II. 2). 
La proporción de muestras positivas para la hoja $\mathrm{N}^{0} 5$ permaneció relativamente estable debido al amarilleo y la caída de la misma en muchas plantas después de los 14 días y, salvo para el primer muestreo en que solo se detectó al patógeno en esas hojas, sus valores fueron iguales o menores que los de la hoja 7 (Figura II.3).

En todas las plantas sintomáticas pudo identificarse positivamente $\mathrm{Cmm}$ por ambos métodos.

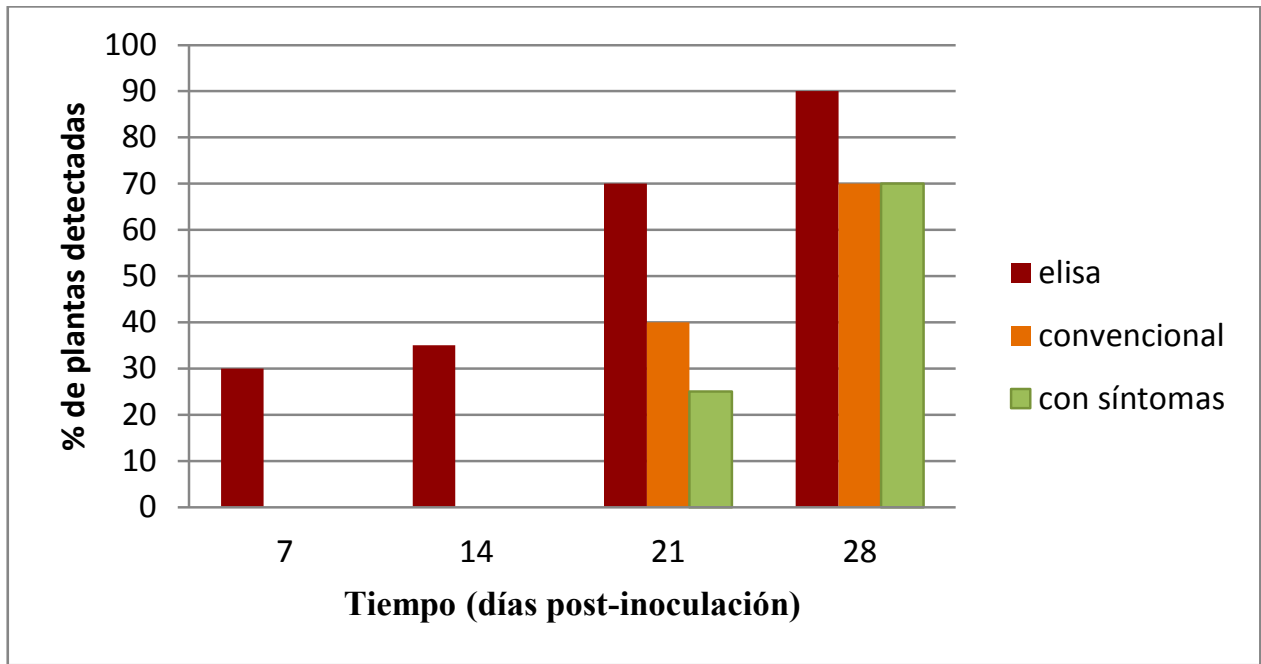

Figura II. 2: Porcentaje de plantas de tomate inoculadas con Clavibacter michiganensis subsp. michiganensis que presentaron síntomas, y en las que se detectó el patógeno por un método serológico (ELISA) o convencional, evaluadas en cuatro ocasiones post inoculación.
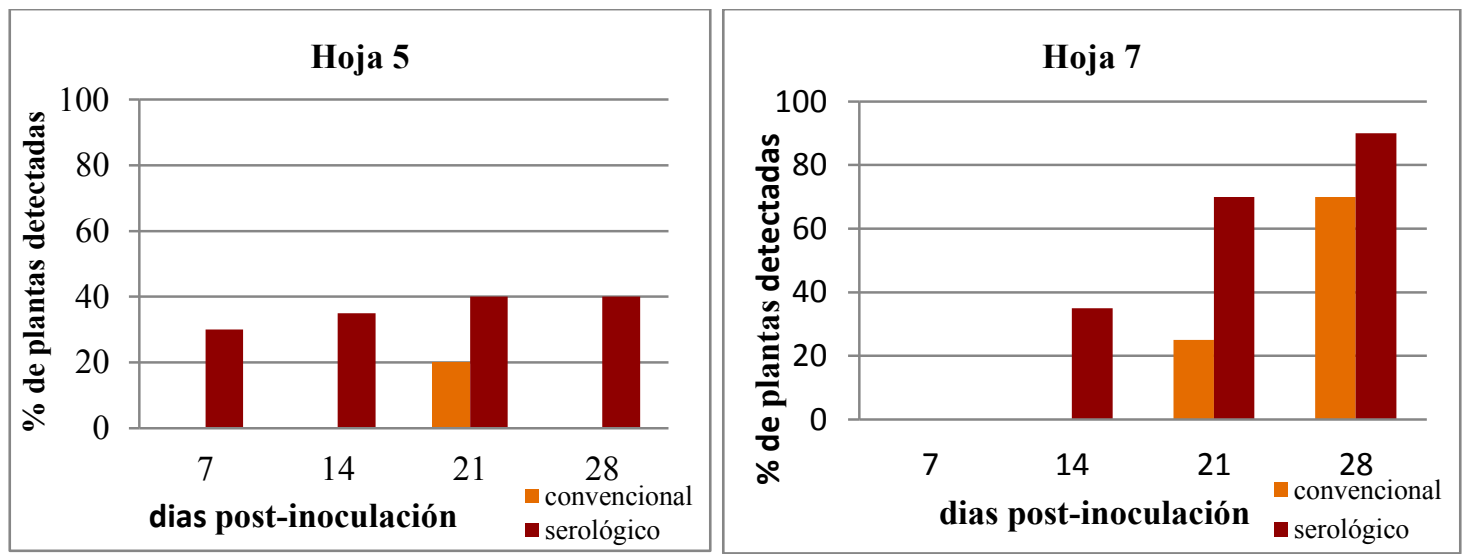

Figura II. 3: Porcentaje de plantas de tomate inoculadas con Clavibacter michiganensis subsp. michiganensis en las que se detectó el patógeno por un método serológico y otro método convencional. A la izquierda resultados de la hoja 5; a la derecha de la hoja 7 


\section{4 DISCUSION}

El método de diagnóstico más efectivo para la detección temprana de $\mathrm{Cmm}$ en plantas de tomate fue el serológico, DAS-ELISA. Esta técnica permitió identificar el patógeno en plantas que no presentaban síntomas de la enfermedad 15 días antes de la aparición de los mismos; además se detectaron por este método una mayor proporción de plantas infectadas que con la técnica de aislamiento e identificación tradicional, en todos los muestreos. La detección temprana del patógeno, cuando las plantas están infectadas pero aún no manifiestan síntomas, es fundamental para la prevención del cancro bacteriano, las prácticas habituales de cultivo podrían contribuir a la dispersión inadvertida del patógeno, causando una epidemia en poco tiempo (Chang y col. 1991; Gitaitis y col. 1991).

Por el método tradicional de aislamiento en placas con medio de cultivo NBY también se detectó la bacteria pero los resultados positivos se observaron recién a las tres semanas de la inoculación, coincidente con la aparición de los síntomas. En ese momento se aisló el patógeno de plantas con síntomas de marchitamiento y también en algunas asintomáticas, aunque el número fue aproximadamente la mitad de las detectadas por serología. Si bien esta técnica es confiable, relativamente económica y permite almacenar cultivos vivos, entre sus desventajas se puede mencionar que es laboriosa, requiere tiempo hasta obtener los resultados y los medios de cultivo pueden contaminarse con otros microorganismos. En este trabajo se utilizó un medio no selectivo, NBY, que no presentó inconvenientes de contaminación. De ocurrir ese problema, podría resolverse con la utilización de medios selectivos o semiselectivos. Este tipo de medios han dado buenos resultados ya que permiten mejorar la sensibilidad de detección de Cmm (Gitatitis y col. 1991; Ftayeh y col. 2011). Sin embargo, generalmente están compuestos por muchos y variados productos químicos (antibióticos, funguicidas, sales, etc.) que en algunos casos pueden ser tóxicos para la salud humana, suelen ser costosos y no siempre están fácilmente disponibles.

La precisión del método de diagnóstico es importante, ya que como se mencionó anteriormente las poblaciones de bacterias que se detectan o aíslan pueden estar constituidas por cepas no patógenas, epífitas o saprófitas que pueden dar falsos positivos, ya sea en medios de cultivo, serología o técnicas moleculares. En el caso del diagnóstico 
con aislamiento del patógeno, este inconveniente puede resolverse realizando pruebas de patogenicidad (López y Cambra 1996; Zaluga y col. 2013).

En este trabajo, el diagnóstico por serología resultó ser el más sensible y rápido porque: $i$ la bacteria se detectó en plantas asintomáticas 15 días antes respecto al método tradicional; ii- la proporción de plantas positivas por serología fue mayor en todos los muestreos; y iiiel resultado puede obtenerse en 48 horas, permitiendo además trabajar con un gran número de muestras. Entre las desventajas de las técnicas serológicas se menciona que no se obtiene un aislamiento de la bacteria y pueden aparecer falsos positivos debido a la presencia de cepas no patógenas (Gorris y col. 1996; Zaluga y col. 2013; Sen y col. 2015). Además hay antisueros que pueden dar reacciones cruzadas, inconveniente que puede resolverse reemplazando el antisuero por anticuerpos monoclonales, consultando a los proveedores sobre su calidad y especificidad, y evaluando la posibilidad de que las bacterias con las que da reacción cruzada estén ausentes en el país.

\section{5 CONCLUSIONES}

El método serológico DAS-ELISA permitió detectar la bacteria $\mathrm{Cmm}$ en plantas de tomate asintomáticas 15 días antes de la aparición de síntomas, antes que la técnica tradicional con aislamiento del patógeno.

Luego de la aparición de síntomas, la proporción de individuos enfermos identificados por serología fue mayor que con método tradicional.

El método de aislamiento tradicional permitió identificar plantas enfermas recién cuando se manifestaron los síntomas de la enfermedad. 


\section{CAPITULO III}

Desinfección de las herramientas de corte durante la conducción del cultivo de tomate

\section{1 INTRODUCCION}

El cancro bacteriano del tomate es una enfermedad vascular causada por Clavibacter michiganensis subsp. michiganensis, patógeno que ingresa a la planta a través de aberturas naturales o heridas. Coloniza principalmente el xilema y conduce a una infección sistémica caracterizada en primer lugar por el marchitamiento de las hojas de un lado de la planta, al avanzar de manera unilateral en el tallo, y culmina con la muerte de la planta (Chalupowicz y col. 2012).

Hasta la fecha no se han logrado obtener cultivares con resistencia genética (Blancard y col. 2011; Sen y col. 2015) y los tratamientos químicos curativos no son muy efectivos. La ubicación de la bacteria en el sistema de conducción de la planta limita el manejo de esta enfermedad ya que los tratamientos químicos más utilizados consisten en la aplicación de formulados en base a cobre, que son preventivos y con acción de contacto, no pudiendo controlar a la bacteria cuando se encuentra en el interior de la planta. Estos productos deberían aplicarse antes de la aparición de los síntomas, aunque esto tampoco garantiza el control porque la enfermedad puede estar en forma latente (Hausbeck y col. 2000; Werner 2002).

Debido a la poca eficacia de los tratamientos curativos, la prevención es crucial. En primer lugar se debería reducir el inóculo inicial de semillas y rastrojos. Las infecciones sistémicas pueden originarse a partir de semilla infectada o infestada externamente (Gleason y col. 1993; Biggerstaff y col. 2000). Un nivel de infección bajo (0,01\%) puede causar una epidemia si las condiciones son favorables (Chang y col. 1991). En consecuencia, es muy importante el análisis de semillas y el mantenimiento de las semillas y plantines libres del patógeno (Jahr y col. 1999; Hausbeck y col. 2000). Por otra parte, Cmm puede sobrevivir en restos de plantas enfermas, tallos y raíces que quedan en el lote cuando finaliza la campaña, constituyendo una fuente de inóculo inicial importante para el siguiente cultivo (Kawaguchi y Tanina 2014). En esta zona se ha determinado una supervivencia del 
patógeno de 3 a 10 meses, según la ubicación del rastrojo en el suelo y si se trata de tomate de primavera (de ciclo temprano), comienza a descomponerse en diciembre, o de verano (de ciclo tardío) empieza a descomponerse en junio (Vega y col. 2010). La persistencia estaría relacionada con la tasa de descomposición del rastrojo (Vega y col. 2011b). Se podría reducir esta fuente de inóculo primario haciendo rotaciones de al menos un año, como sugieren los resultados del capítulo I, mediante la incorporación del rastrojo, u otros tratamientos que aceleren su descomposición.

Otra manera de prevención es reduciendo la dispersión del inóculo secundario. Una vez instalada la enfermedad en el cultivo, la bacteria se propaga desde las plantas enfermas a las sanas durante las prácticas normales de manejo del cultivo, e ingresa por las heridas que se producen durante el trasplante, y las prácticas de desbrote, deshoje, raleo de flores y frutos que se realizan desde las etapas tempranas en los cultivos (Gleason y col. 1993; Jones y col. 2001). Aun cuando las plantas muestren muy buen estado sanitario, sin manifestar síntomas de cancro bacteriano, puede haber plantas con infecciones latentes. En estas circunstancias, y con la ayuda de las herramientas de trabajo, el patógeno se propaga rápidamente a lo largo de la hilera (Chang y col. 1991; Gitaitis y col. 1991), pudiendo observarse líneas completas de plantas contiguas con marchitamiento (Figura III. 1). Esta forma de distribución de la enfermedad es característica dentro de los invernaderos (Kawaguchi y col. 2010). Por esta razón se recomienda la desinfección del instrumental de poda.

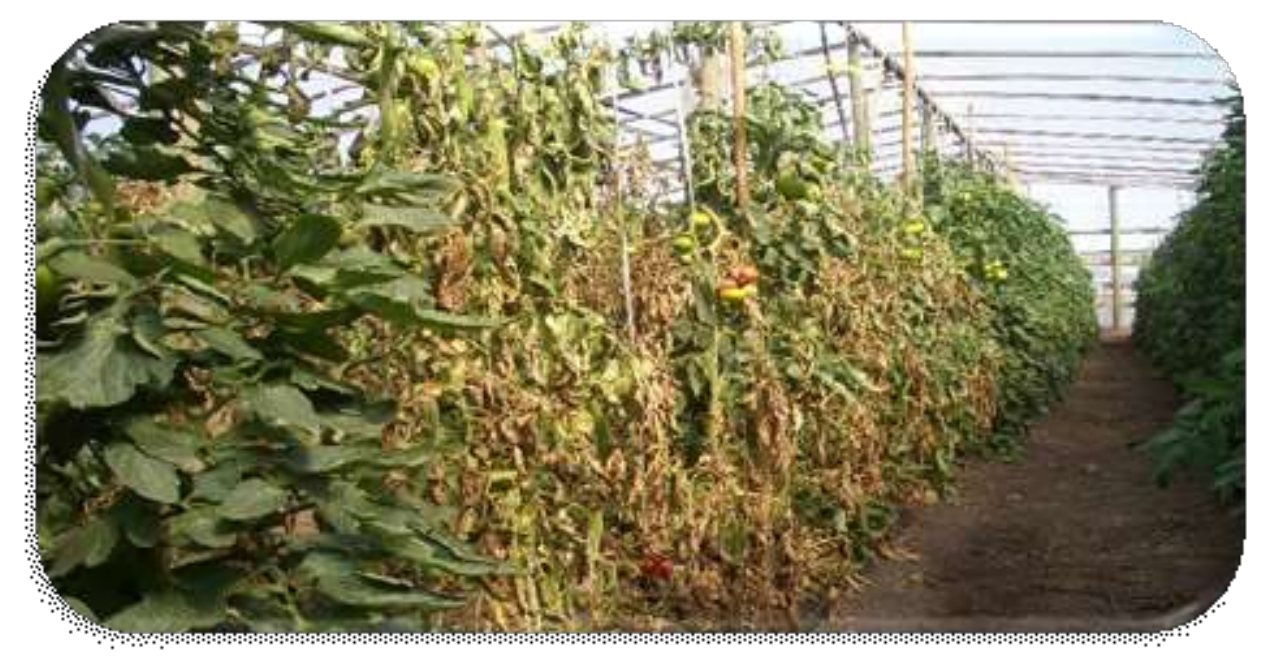

Figura III. 1: Distribución del cancro bacteriano en la hilera de cultivo. Transmitido por las herramientas de trabajo en el momento de las labores culturales. Cultivo de tomate bajo cubierta en el CHP. 
Entre los desinfectantes recomendados para evitar la dispersión de Cmm están los compuestos clorados, como el hipoclorito de calcio $(0,2 \%)$ y de sodio $(0,3 \%$; lavandina al 5 \%) (Kawaguchi y col. 2010; Rista y col. 2005b). Otros compuestos, como el cloruro de benzalconio (1\%) y el alcohol (70\%), han mostrado ser totalmente eficaces en ensayos en maceta (Vega y col. 2009), aunque no fueron evaluados en situaciones de cultivo.

En el CHP un grupo de productores utiliza sulfato de oxiquinoleína (Almacigol, Triavet S.A.) en plantas ornamentales para la desinfección de herramientas usadas para las tareas de desbrote y limpieza de plantas, con buenos resultados en la disminución de la transmisión de enfermedades vasculares (comunicación personal Susana Gamboa). Este producto se utiliza frecuentemente como fungicida para el control del "mal de los almácigos"; tiene acción sistémica, es curativo y preventivo, y presenta la ventaja de ser Clase IV en la categoría de productos químicos, lo que significa que normalmente no ofrece peligro en su manipulación.

El cloruro de benzalconio, un amonio cuaternario, es un desinfectante también usado como antiséptico en cremas y jabones. Tiene la desventaja de que su actividad se reduce con la materia orgánica y es sensible a la dureza del agua. La actividad del cloro también disminuye con la materia orgánica y puede ser corrosivo con las herramientas de poda lo que podría reducir la vida útil de las mismas (OMS 2005).

El objetivo de este trabajo fue evaluar la efectividad de distintos desinfectantes sobre las herramientas de corte usadas en las labores de rutina. 


\section{2 MATERIALES Y METODOS}

\section{2. 1 Diseño del experimento}

El ensayo se realizó en invernadero con plantas en tierra, en la Estación Experimental Gorina del Ministerio de Asuntos Agrarios de la provincia de Buenos Aires. Se utilizaron plantines adquiridos en plantinera comercial, del hibrido Elpida (Syngenta). El experimento se repitió en dos años, trasplantándose en diciembre de 2009 y en enero de 2011.

Se evaluaron 252 plantas, distribuidas en 28 hileras con una distancia de $1 \mathrm{~m}$ entre hileras y 0,45 m entre plantas. Cada hilera tenía tres tratamientos con 3 plantas/tratamiento (unidad experimental), separados entre sí y en los extremos con plantas bordura.

El experimento tuvo un diseño con bloques al azar con 14 repeticiones de cada tratamiento. Cada bloque se conformó con dos hileras de tal manera que entraran los seis tratamientos, los que se ubicaron al azar en cada repetición (bloque) (Figura III.2).

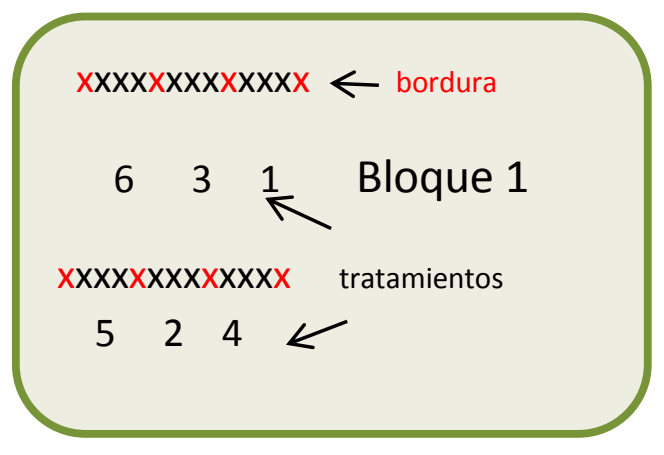

Figura III.2 Esquema representando la distribución de tratamientos dentro de un bloque. Cada bloque consistió de dos hileras de plantas. Las plantas están representadas con una X. Las rojas son plantas usadas como bordura para separar tratamientos.

III. 2. 2 Inoculación y aplicación de tratamientos

Como fuente de inóculo se utilizaron 14 plantas adultas infectadas provenientes de lotes productivos comerciales que se colocaron en maceta en las cabeceras de cada repetición en el momento de la práctica. Las mismas fueron previamente analizadas para comprobar la presencia del patógeno. La inoculación se realizó una sola vez, en el momento del primer desbrote, cuando las plantas tenían entre 10-12 hojas. La misma consistió en realizar un 
pequeño tajo en el tallo de la planta enferma, sumergir la cuchilla en el envase con el desinfectante correspondiente y luego desbrotar la planta sana.

Se evaluaron tres desinfectantes, hipoclorito de sodio, cloruro de benzalconio y sulfato de oxiquinoleína. Las diluciones de los productos se realizaron con agua destilada.

Como controles enfermos se usaron plantas que se cortaron con una cuchilla sin desinfectar y otras con la cuchilla sumergida en agua, y como control sano los desbrotes se realizaron consecutivamente entre plantas sanas.

Tratamientos:

1- Cloruro de benzalconio (Química Oeste S.A.) $1 \%$

2- Sulfato neutro de oxiquinoleína (Almacigol, Triavet S.A.) 0,01\%

3- Hipoclorito de sodio, cloro activo $1 \%$

4- Testigo inoculado, agua

5- Testigo inoculado

6- Testigo sano

\section{2. 3 Evaluación}

Se realizaron cinco observaciones, con una frecuencia semanal a partir de la aparición de los primeros síntomas. Se registró la incidencia (porcentaje de plantas enfermas por unidad experimental; $\mathrm{n}=3$ ), y la altura alcanzada por los síntomas de la enfermedad en cada planta. Para analizar esta última variable, se promedió la altura a la que llegaron los síntomas en las tres plantas que constituyeron una unidad experimental, para cada repetición. Con los datos de altura de los síntomas a lo largo del tiempo se calculó el área bajo de curva de progreso de la enfermedad (ABCPE) (Campbell y Madden 1990). En cada fecha en que se hicieron las observaciones se cosecharon los frutos maduros de todas las plantas y se pesaron juntos los correspondientes a cada tratamiento.

La duración de los ciclos del cultivo desde trasplante a fin de cosecha para los dos años evaluados 2010 y 2011 fueron de 105 y 93 días respectivamente con un período de cosecha de 46 días en el primer año y 32 días en el segundo. 
La identificación presuntiva de la bacteria se hizo utilizando inmunotiras para $C$. michiganensis subsp. michiganensis (Agdia Inc.) para luego ser corroboradas en laboratorio por técnicas microbiológicas y biológicas.

Se realizó un análisis de varianza (ANOVA) de los datos y luego el test de mínima diferencia significativa (LSD, Fischer; $\alpha=0,05)$ para evaluar diferencias entre tratamientos, previa verificación de los supuestos del modelo, con el programa estadístico Infostat (Infostat 2009). 


\section{3 RESULTADOS}

III. 3. 1 Incidencia

En el año 2010, hubo diferencias significativas entre tratamientos para todas las fechas evaluadas (ANOVA; fecha 1, $\mathrm{p}=0,0002$; fecha 2, $\mathrm{p}=0,0001$; fechas 3, 4 y 5, p < 0,0001). La incidencia de plantas con cancro bacteriano fue significativamente menor (LSD, $\alpha=0,05$ ) cuando la herramienta se desinfectó con cloruro de benzalconio que cuando no se desinfectó o cuando la cuchilla se sumergió en agua (controles inoculados), para todas las fechas (Figura III.2). La desinfección con hipoclorito de sodio y sulfato de oxiquinoleína fueron semejantes entre si, y con valores intermedios entre las plantas no inoculadas (control sano) y el control inoculado sin desinfección. Sin embargo, en ninguna fecha fueron diferentes del control inoculado en el que la cuchilla se había sumergido en agua (LSD, $\alpha=0,05$; Figura III.3).

En el año 2011, los tratamientos fueron significativamente distintos en todas las fechas evaluadas (ANOVA; $\mathrm{p}<0,0001$ ). En ninguna fecha hubo diferencias significativas en la incidencia de plantas enfermas entre desinfectantes, ni entre éstos y el control sano. Por el contrario, los controles inoculados, tanto en los que no se desinfectó la cuchilla como en aquellos en los que se sumergió en agua, tuvieron una incidencia significativamente mayor que el resto de los tratamientos (LSD, $\alpha=0,05$; Figura III.4). 


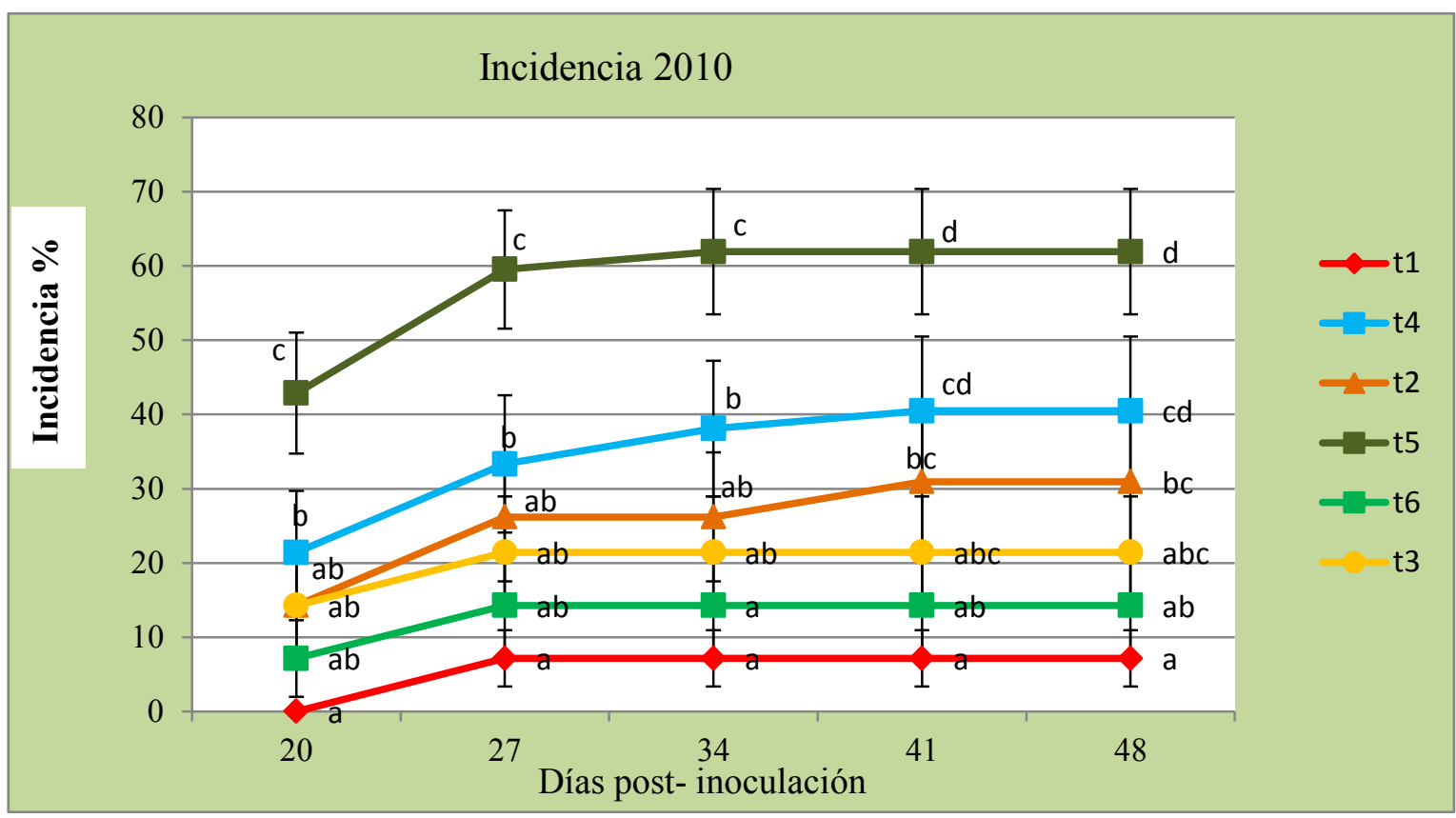

Figura III. 3: Incidencia de plantas con cancro bacteriano, para los distintos desinfectantes de herramientas. Año 2010. Tratamientos: 1-Cloruro de Benzalconio (1\%), 2, Sulfato de oxiquinoleína $(0,01 \%), 3$ - Hipoclorito de sodio (1 \%), 4-Agua, 5-Testigo Inoculado, 6-Testigo sano. Letras minúsculas diferentes sobre las curvas indican diferencias significativas. Las barras sobre los puntos representan el error estándar.

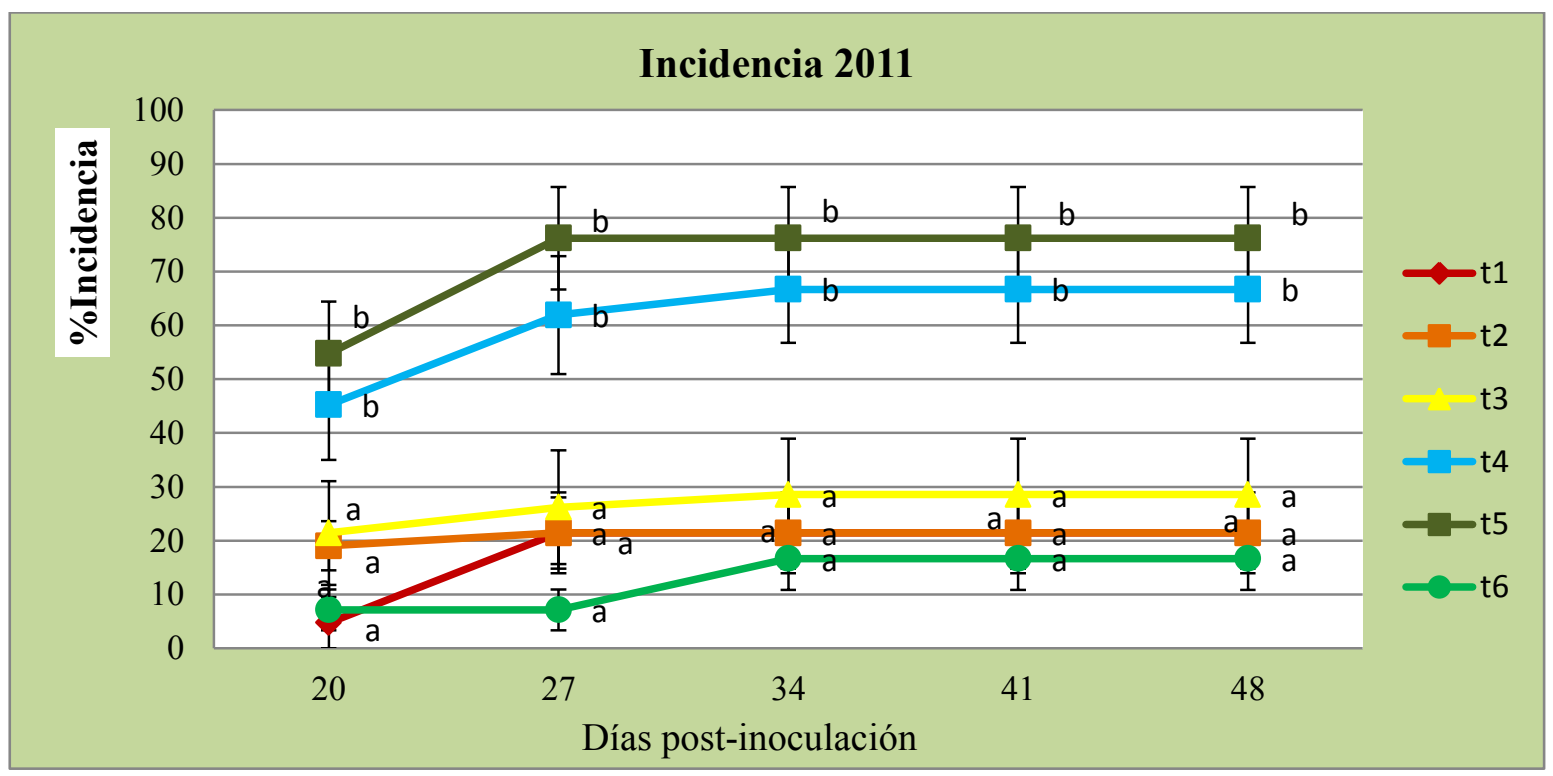

Figura III. 4: Incidencia de plantas con cancro bacteriano, para los distintos desinfectantes de herramientas. Año 2011. Tratamientos: 1-Cloruro de Benzalconio (1\%), 2, Sulfato de oxiquinoleína $(0,01 \%)$, 3- Hipoclorito de sodio (1 \%), 4-Agua, 5-Testigo inoculado, 6Testigo sano. Letras minúsculas diferentes sobre las curvas indican diferencias significativas. Las barras sobre los puntos representan el error estándar. 
III. 3. 2 Altura alcanzada por los síntomas

En el año 2010, hubo diferencias significativas entre tratamientos para todas las fechas evaluadas (ANOVA; fecha 1, p =0,0001; fecha 2, 3, 4 y 5 p < 0,0001). Los síntomas de la enfermedad llegaron a una altura significativamente más alta en las plantas inoculadas que en el resto (LSD, $\alpha=0,05$ ), para todas las fechas analizadas (Figura III. 4). Los valores más bajos correspondieron a las plantas en las que las cuchillas se desinfectaron con cloruro de benzalconio; sus valores fueron significativamente más bajos que los de las plantas en las que se usó agua, a partir de la tercera observación (LSD, $\alpha=0,05$; Figura III.4). La altura a la que llegaron los síntomas en las plantas en las que las cuchillas se desinfectaron con hipoclorito de sodio y con sulfato de oxiquinoleína tuvieron valores intermedios entre las plantas no inoculadas (control sano) y el control inoculado sin desinfección. En ninguna fecha fueron diferentes del control inoculado en el que la cuchilla se había sumergido en agua (LSD, $\alpha=0,05$; Figura III.5).

En 2011, los tratamientos fueron significativamente distintos en todas las fechas evaluadas (ANOVA; $\mathrm{p}<0,0001$ ). El testigo sano, la desinfección con cloruro de benzalconio, con sulfato de oxiquinoleína y con hipoclorito de sodio resultaron en plantas en las que los síntomas llegaron a una altura significativamente más baja que en el tratamiento con agua y el testigo inoculado no desinfectado (LSD, $\alpha=0,05$ ) (Figura III. 6) 


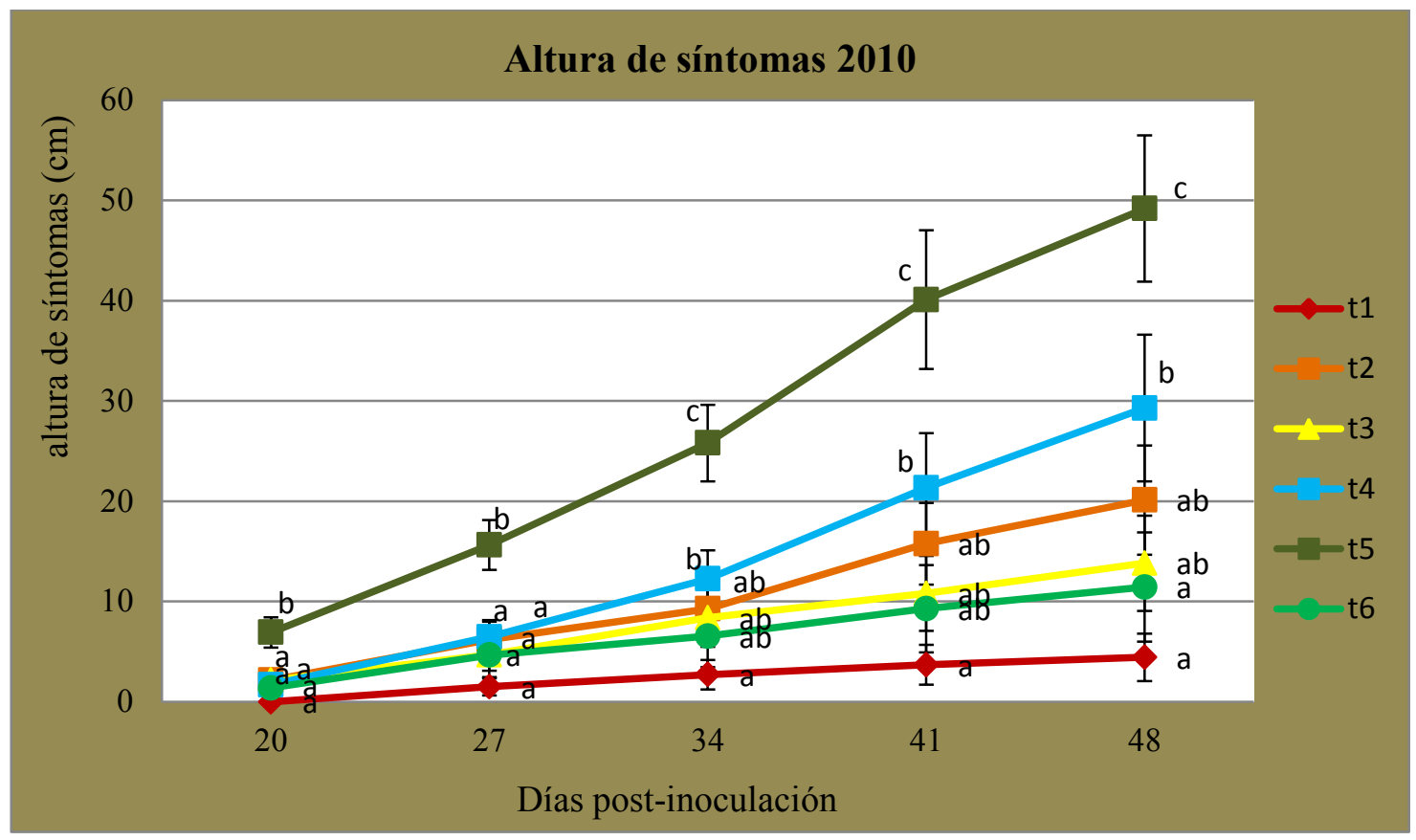

Figura III. 5: Altura (cm) alcanzada por los síntomas de la enfermedad para los distintos desinfectantes de herramientas. Año 2010. Tratamientos: 1-Cloruro de Benzalconio (1\%), 2, Sulfato de oxiquinoleína $(0,01 \%), 3$ - Hipoclorito de sodio (1 \%), 4-Agua, 5-Testigo Inoculado, 6-Testigo Sano. 14 repeticiones y tres plantas por tratamiento en cada repetición. Las barras sobre los puntos representan el error estándar.

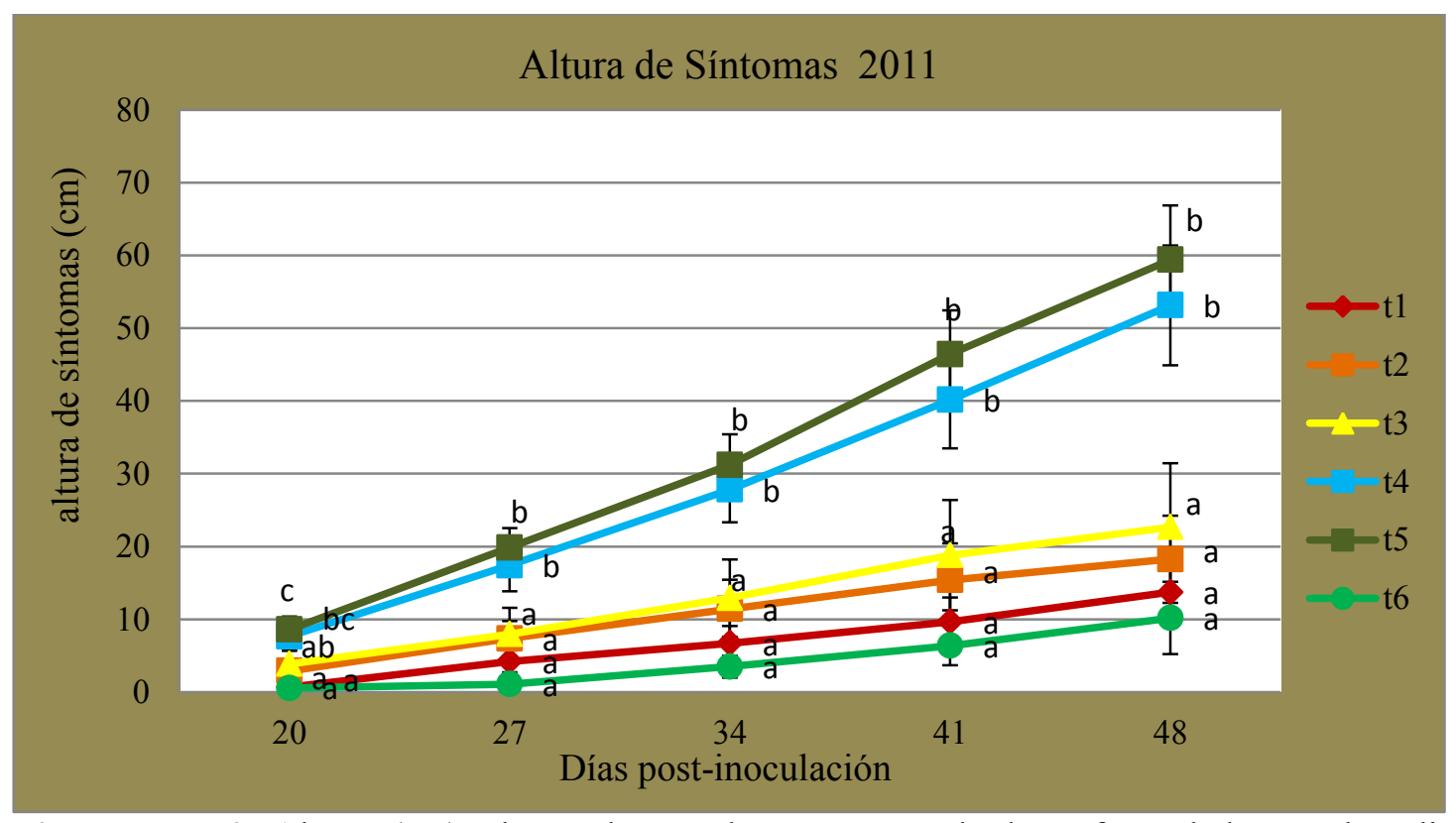

Figura III. 6: Altura (cm) alcanzada por los síntomas de la enfermedad para los distintos desinfectantes de herramientas. Año 2011. Tratamientos: 1-Cloruro de Benzalconio (1\%), 2, Sulfato de oxiquinoleína $(0,01 \%)$, 3- Hipoclorito de sodio (1\%), 4-Agua, 5-Testigo Inoculado, 6-Testigo Sano. 14 repeticiones y tres plantas por tratamiento en cada repetición. Las barras sobre los puntos representan el error estándar. 
III. 3. 3 Area Bajo la Curva de Progreso de la Enfermedad (ABCPE)

En el año 2010 se detectaron diferencias entre los tratamientos (ANOVA; $p<0,0001$ ). El tratamiento con cloruro de benzalconio tuvo un ABCPE significativamente menor que el tratamiento con agua y el testigo inoculado no desinfectado (LSD, $\alpha=0,05$ ). Si bien este desinfectante mostró el mejor comportamiento, no se encontraron diferencias con los otros desinfectantes probados, sulfato de oxiquinoleína e hipoclorito de sodio (LSD, $\alpha=0,05$ ). Estos últimos también mostraron diferencias con el testigo inoculado sin desinfección, sin embargo no registraron diferencias respecto al tratamiento con agua (Figura III.7).

En el año 2011, también hubo diferencias entre los tratamientos (ANOVA; p < 0,0001). Si bien no se encontraron diferencias significativas (LSD, $\alpha=0,05$ ) entre los tres desinfectantes (cloruro de benzalconio, sulfato de oxiquinoleína e hipoclorito de sodio), el cloruro de benzalconio es el que registró el menor valor de ABCPE. En este año, el testigo inoculado y el tratamiento con agua se diferenciaron significativamente de los tres desinfectantes y del testigo sano (LSD, $\alpha=0,05$; Figura III.8).

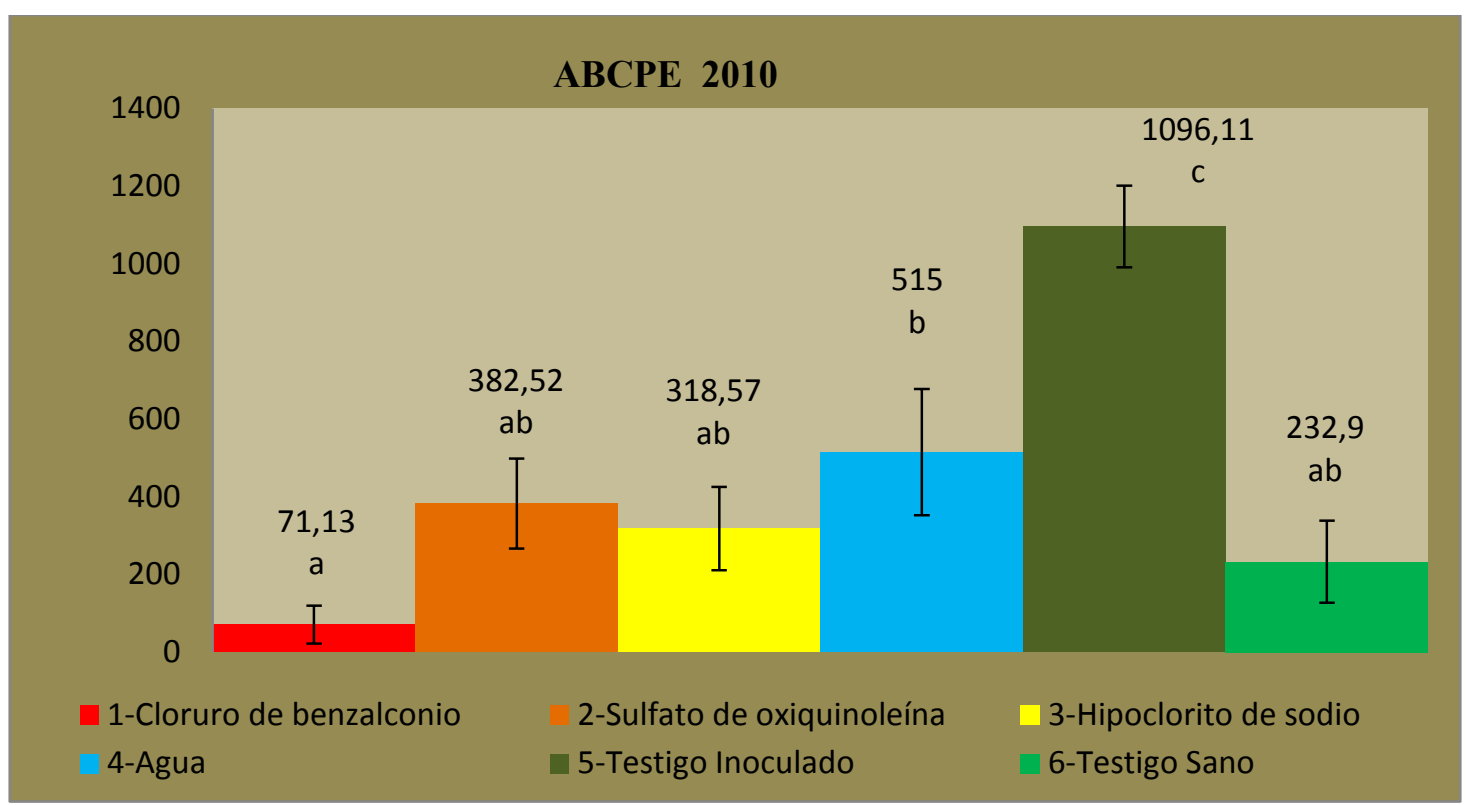

Figura III. 7: Area Bajo la Curva de Progreso de la Enfermedad correspondiente al año 2010. Tratamientos: 1-Cloruro de Benzalconio (1\%), 2, Sulfato de oxiquinoleína (0,01\%), 3- Hipoclorito de sodio (1 \%), 4-Agua, 5-Testigo Inoculado, 6-Testigo Sano. Letras minúsculas diferentes sobre las barras indican diferencias significativas. ABCPE: Calculada a partir de altura alcanzada por el síntoma de la enfermedad, con 14 repeticiones y tres plantas por tratamiento en cada repetición. Las barras representan el error estándar. 


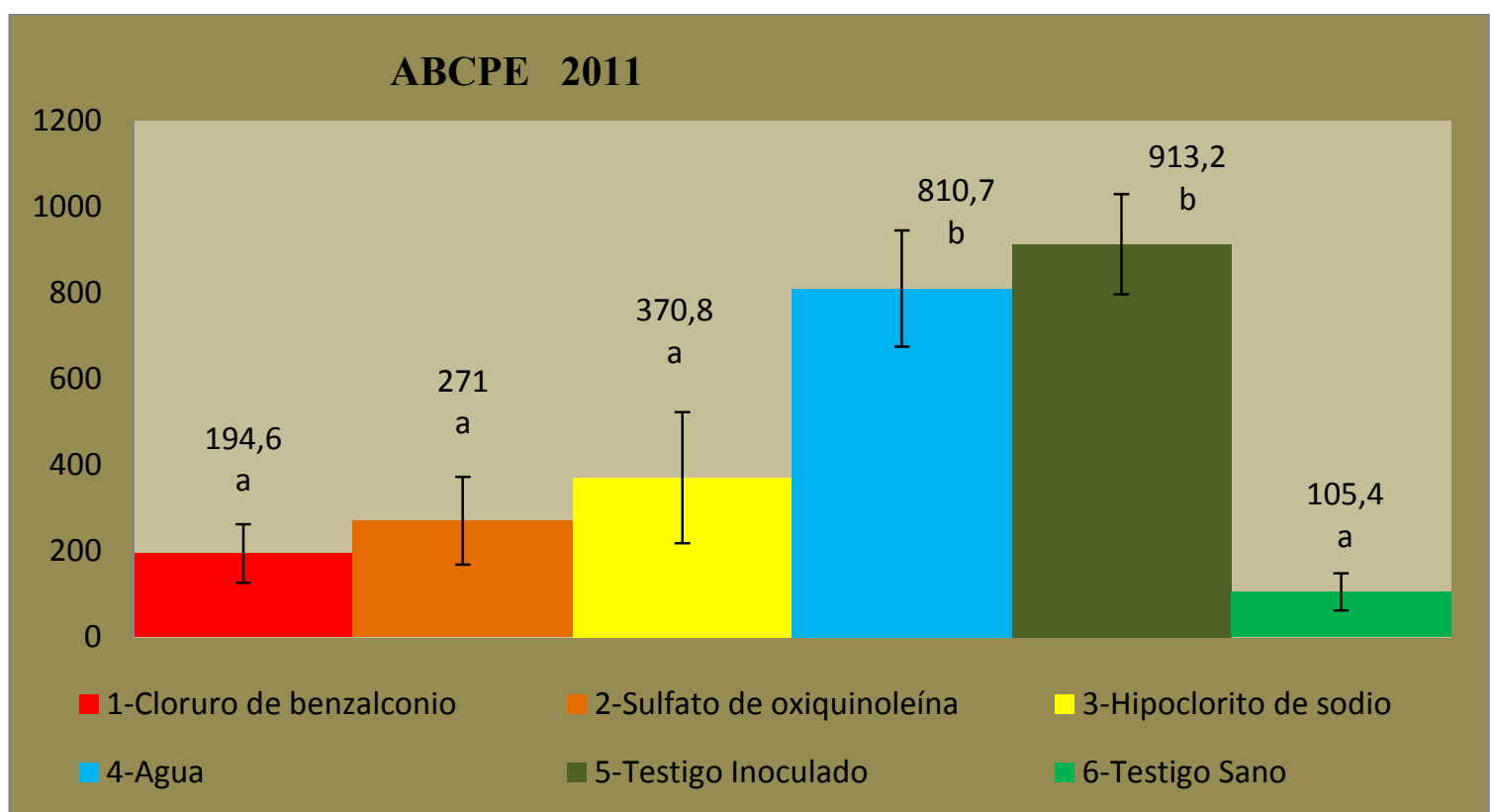

Figura III. 8: Area Bajo la Curva de Progreso de la Enfermedad correspondiente al año 2011. Tratamientos: 1-Cloruro de Benzalconio (1\%), 2, Sulfato de oxiquinoleína (0,01\%), 3- Hipoclorito de sodio (1\%), 4-Agua, 5-Testigo Inoculado, 6-Testigo Sano. Letras minúsculas diferentes sobre las barras indican diferencias significativas. ABCPE: Calculada a partir de altura alcanzada por el síntoma de la enfermedad, con 14 repeticiones y tres plantas por tratamiento en cada repetición. Las barras representan el error estándar.

\section{3. 4 Rendimiento}

En los dos años que se realizó el experimento se observó una tendencia a un mayor rendimiento promedio por planta para el tratamiento con el desinfectante cloruro de benzalconio junto con el testigo sano.

Los menores rendimientos se registraron en el testigo inoculado no desinfectado y el testigo tratado con agua (Cuadro III.1). 
Tratamientos

$2010 \quad 2011$

g/planta g/planta

1-Cloruro de benzalconio 1\% $321 \quad 297$

2-Sulfato de oxiquinoleína 0,01\% $300 \quad 257$

3-Hipoclorito de sodio 1\% $299 \quad 270$

4-Agua $263 \quad 218$

5-Testigo Inoculado $239 \quad 215$

6-Tesigo Sano $299 \quad 315$

Cuadro III. 1 Rendimiento promedio por planta para cada tratamiento. Años 2010 y 2011. Para el período del ensayo.

\section{4 DISCUSION}

La forma en que se disemina el cancro bacteriano a lo largo de las hileras, mostrando rápidamente surcos completos de plantas de tomate marchitas se debe principalmente a la facilidad con que se dispersa el patógeno durante las labores de conducción del cultivo, como la poda, el desbrote y el deshoje, entre otros (Kawaguchi y col. 2010). Esta dispersión secundaria del inóculo puede disminuirse si se desinfectan las herramientas de corte (Kawaguchi y col. 2010; Rista y col. 2005b). En este trabajo se demostró la efectividad de tres productos, cloruro de benzalconio, hipoclorito de sodio y sulfato de oxiquinoleína, en cultivos de tomate en suelo en invernadero, durante dos años.

No hubo diferencias significativas en la efectividad de los tres productos evaluados para la desinfección de las cuchillas de corte sobre la incidencia de plantas con cancro bacteriano y la altura alcanzada por los síntomas. Esta última fue una forma de estimar cuantitativamente los niveles de enfermedad que manifestaban las plantas. Sin embargo, los dos años evaluados el cloruro de benzalconio fue el producto que tuvo valores más bajos de incidencia, altura de los síntomas en las plantas y ABCPE. El cloruro de benzalconio es un amonio cuaternario utilizado también como antiséptico en jabones y cremas de uso humano. Por ser sensible a la dureza del agua (OMS 2005), en lugares donde el agua es 
dura o dudosa la solución de uso debería prepararse con agua destilada. En este trabajo resultó efectivo en una dilución al $1 \%$, tal como fue informado en ensayos realizados con plantas en maceta; diluciones menores serían menos efectivas (Vega y col. 2009).

El hipoclorito de sodio también fue efectivo para reducir la dispersión del patógeno. Los niveles de incidencia de plantas enfermas, altura de los síntomas y el ABCPE fueron muy similares a los alcanzados con el sulfato de oxiquinoleína. La concentración usada, $1 \%$, fue un poco más alta que la informada por Rista y col (2005b), quienes lo usaron al 0,3\%, con resultados semejantes a los informados en este trabajo. La desventaja de este producto es que es corrosivo (OMS 2005), por lo que podría afectar la vida útil de las herramientas. Además, por ser fuertemente oxidante puede causar quemaduras en la piel.

La información disponible sobre el sulfato de oxiquinoleína es más escasa. Actualmente se lo utiliza como fungicida en el momento de siembra, pre y post emergencia de plantines, y algunos productores del CHP lo usan también en la desinfección de herramientas.

El efecto de los tres productos podría deberse, en parte, a la dilución del inóculo bacteriano presente en las cuchillas en el líquido del desinfectante. En el ensayo de 2010 los niveles más altos de enfermedad se alcanzaron cuando no se sumergió la cuchilla en ningún tipo de líquido. La inmersión de las herramientas en agua, aunque produjo niveles más altos de incidencia y altura de síntoma en las plantas que cualquiera de los desinfectantes, no fue estadísticamente diferente de los logrados con el hipoclorito de sodio o el sulfato de oxiquinoleína. En el 2011 no se produjo este efecto.

Estos resultados permiten confirmar que el uso de productos desinfectantes en las cuchillas de corte durante las labores culturales contribuye a la disminución de la propagación del cancro bacteriano en el cultivo de tomate. Esta práctica no sólo resultó ser beneficiosa en la disminución del número de plantas enfermas, sino también en una menor altura de síntomas, menor ABCPE y una tendencia a mayores rendimientos en aquellas plantas dónde se utilizaron desinfectantes.

Es importante tener en cuenta, que estas prácticas preventivas deben realizarse desde el primer momento de instalado el cultivo, ya que se ha demostrado que desde los estados iniciales y al menos hasta el desarrollo de las hojas 17-18, es el período de mayor vulnerabilidad para que, si ingresa la bacteria, pueda ocasionar síntomas de marchitamiento que lleven a la muerte de la planta (Sharabani y col. 2013). Por esta razón, la incorporación 
de estas prácticas preventivas debe tener en cuenta también el momento de mayor susceptibilidad de la planta.

\section{5 CONCLUSIONES}

El uso de desinfectantes, tales como el cloruro de benzalconio al $1 \%$, el sulfato de oxiquinoleína al 0,01\% y el hipoclorito de sodio al $1 \%$, en las cuchillas de corte durante las labores culturales permite disminuir la propagación del cancro bacteriano del tomate.

De estos tres desinfectantes ensayados, el cloruro de benzalconio al $1 \%$ permitió obtener los mejores resultados.

Al menos en uno de los dos años, el efecto de los tres productos podría deberse en parte a la dilución del inóculo presente en las cuchillas en el líquido del desinfectante. 


\section{CONCLUSIONES GENERALES}

En este estudio fue posible esclarecer la situación del cancro bacteriano del tomate en el CHP, durante el período estudiado. Se demostró que la enfermedad está ampliamente difundida en la zona; se la detectó en las nueve localidades evaluadas. Según el año, el antecesor, tipo e híbrido de tomate plantado, y otras particularidades de cada caso, llegó a afectar el $100 \%$ de las plantas de un cultivo. Conocer esta situación permitirá a las asociaciones de productores y los organismos del estado establecer prioridades, planificar e implementar estrategias de manejo y políticas de financiamiento focalizadas a la reducción de esta grave enfermedad.

Se identificó, además, un método de diagnóstico que posibilitó detectar la enfermedad en estado latente, de forma rápida y con una técnica aplicable a laboratorios de nivel tecnológico intermedio, la técnica serológica DAS-ELISA. La misma permitió la detección de la bacteria $\mathrm{Cmm}$ dos semanas antes que el método de aislamiento tradicional y que la aparición de los síntomas. Los productores tendrán la posibilidad de obtener un diagnóstico correcto en aproximadamente 48 horas, y así contar con el tiempo suficiente para implementar medidas de manejo preventivas.

Para evitar la dispersión secundaria de $\mathrm{Cmm}$ en el cultivo es fundamental desinfectar las herramientas de corte. En este trabajo se determinó la efectividad de tres desinfectantes al alcance de todos los productores, el cloruro de benzalconio, el hipoclorito de sodio y el sulfato de oxiquinoleína. El cloruro de benzalconio permitió alcanzar los niveles más bajos de transmisión, al tiempo que no presenta los inconvenientes de ser corrosivo sobre las herramientas ni irritante sobre la piel de los operarios que tiene el hipoclorito de sodio.

Los resultados obtenidos en este trabajo permiten hacer nuevos planteos a resolver en futuras investigaciones, como establecer el nivel de susceptibilidad de los tomates de tipo cherry comparada con los tipos redondo y perita. De verificarse la hipótesis de una mayor resistencia del primer grupo, podría plantearse su uso en invernaderos con historia de una alta incidencia de cancro bacteriano. También sería conveniente determinar la importancia del descanso del suelo y de los cultivos antecesores, sobre los niveles de la enfermedad. 


\section{BIBLIOGRAFIA}

Agrios, G.N. 2005. Plant Pathology. Department of Plant Pathology, University of Florida. Fifth Edition. Elsevier Academic Press, Pp. 922.

Alippi, A.M.; Dal Bó, E.; Ronco, L.E.; López, M.V.; Aguilar, M. 2003. Pseudomonas populations causing pith necrosis of tomato and pepper in Argentina are highly diverse. Plant Pathology 52: 287-302.

Alippi, A.M y López, M.V. 2010. First report of Pseudomonas mediterranea causing pith necrosis in Argentina. Plant Pathology 59: 1163.

Amma, A.; Francescangeli, N.; Marti, H.; Mitidieri, M.; Mitidieri, A.; Murray, R.; Paunero, I.; Piola, M.; Polack, A.; Polenta, G.; Balcaza, L.; Fernández, R.; Pineda, C.; Lange, P. 2004. Plan Tecnológico Regional 2006-2008. Informe Diagnóstico de Situación. Cadena Hortícola. Ediciones INTA.

Alarcón, C.; Castro, J.; Muñoz, F.; Arce-Johnson, P. and Delgado, J. 1998. Protein(s) from the Gram-Positive Bacterium Clavibacter michiganensis subsp. michiganensis Induces a Hipersensitive Response in Plants. Phytopathology 4:306-310.

Atlas Fitopatológico Argentino. Editores: Nome, S.F.; Docampo, D.H.; Conci, L.R. ISSN 1851-8974. Córdoba, Argentina. Actualizado marzo 2015. URL Consulta: 7/4/15 http://rian.inta.gov.ar/atlas/\#/ResultadoMapa?IdHospedante $=0 \&$ IdTipocultivo $=0 \&$ IdPatoge $\underline{\text { no }=3567}$

Barnes, L.W.1994. The role of plants clinics in disease diagnosis and education. A North American Perspective. Annual Review of Phytopathology 32: 601-609. 
Biggerstaff, C; Gleason, M. L y Braun E. 2000. Refinement of a nondestructive tomato seed assay for Clavibacter michiganensis subsp. michiganensis using seed fiber. Seed Science and Technology 28: 261-269.

Blancard, D. 1996. Enfermedades del Tomate. Observar, Identificar, Luchar. Edición Española. Ediciones Mundi -Prensa. Madrid, España. ISBN 84-7114-265-1, Pp. 212

Blancard, D.; Laterrot, de H.; Marchoux, G. y Candresse, T. 2011. Enfermedades del Tomate: Identificar, conocer, controlar. Ed. Quae, Mundi-Prensa. Consulta 7/4/15 https://books.google.com.ar/books?isbn=8484764273

Borboa Flores, J.; Rueda Puente, E. O.; Acedo Félix, E.; Ponce, J. F.; Cruz, M.; Grimaldo Juárez, O.; García Ortega, A. M. 2009. Detección de Clavibacter michiganensis subsp. michiganensis en el tomate en el Estado de Sonora, México. Revista Fitotecnia Mexicana 32: 319-326.

Bradbury, J.F. 1986. Guide to Plant Pathogenic Bacteria. Wallingford, UK: CAB International.

CABI. 2014. Centre for Agricultural Bioscence International. Datasheet: Clavibacter michiganensis subsp. michiganensis (bacterial canker of tomato) Consulta 5/11/14 www.cabi.org/isc/datasheet/15338

Campbell, C.L. and Madden, L. V. 1990. Introducción a la Epidemiología de las Enfermedades de las Plantas. Wiley-Interscience, New York, 532pp.

Carlton, W.M.; Braun, E.J. y Gleason, M.L.1998. Ingress of Clavibacter michiganensis subsp. michiganensis into Tomato Leaves Through Hydathodes. Phytopathology. 88: 525529. 
CHBA. 1998. Censo Hortícola del Cinturón Verde de Buenos Aires. Ministerio de Asuntos Agrarios de la Provincia de Buenos Aires y Secretaria de Agricultura, Pesca y Alimentación de la Nación.

CHFBA. 2005. Censo Horti- Florícola Provincial de Buenos Aires. Ministerio de Asuntos Agrarios de la Provincia de Buenos Aires, Consejo Federal de Inversiones y Secretaria de Agricultura, Ganadería, Pesca y Alimentación de la Nación.

Chang, R.J.; Ries, S.M.; Pataky, J.K.1991. Dissemination of Clavibacter michiganensis subsp. michiganensis by Practice Used to Produce Tomato Transplants. Phytopathology 81: 1276-1281.

Chang, R.J.; Ries, S.M.; Pataky, J.K. 1992. Reductions in yield of processing tomatoes and incidence of bacterial canker. Plant Disease, 76: 805-806.

Chapulowicz, L.; Zellerman, E-M.; Fluegel, M.; Dror, O.; Eichenlaub, R.; Garteman, K-H.; Savidor, A.; Sessa, G.; Iraki, N.; Barash, I. y Manulis-Sasson, S. 2012. Colonization and Movement of GFP-Labeled Clavibacter michiganensis subsp. michiganensis During Tomato Infection. Phytopathology, 102: 23-31.

Coaker, G., y Francis, D. 2003. Mapping, genetic effects, and epistatic interaction of two bacterial canker resistance QTLs from Lycopersicon hirsutum. Theor. Appl. Genet. 108:1047-1055.

Coaker, G., Willard, B., Kinter, M., Stockinger, E., and Francis, D.2004. Proteomic Analysis of Resistance Mediated by Rcm 2.0 and Rcm 5.1, Two Loci Controlling Resistance to Bacterial Canker of Tomato. Molecular Plant-Microbe Interactions 17: 10191028.

Corvo Dolcet. 2005. Zonas de producción del cultivo de tomate en la Argentina. Secretaría de Agricultura, Ganadería, Pesca y Alimentos. 
Davis, M. J.; Gillaspie, A.G.Jr.; Vidaver, A.K.; Harris, R.W. 1984. Clavibacter: a new genus containing some phytopathogenic Coryneform bacteria, including Clavibacter xyli subsp. xyli sp. nov., subsp. nov., and Cavibacter xyli subsp. cynodonis subsp. nov., pathogens that cause Ratoon stunting disease of sugarcane and Bermudagras stunting disease. International Journal of Systematic Bacteriology 34:107-117.

De León, L.; Llop, P.; López, M.M. y Siverio, F. 2009. Comparative study of genetic diversity of Clavibacter michiganensis subsp. michiganensis isolates from the Canary Islands by RAPD-PCR, BOX-PCR y AFLP. Plant Pathology 58: 862-871.

De León, L., Rodríguez, A.; López, MM, y Siverio, F. 2007. Evaluación de la eficacia de la separación inmunomagnética para la detección de Clavibacter michiganensis subsp. michiganensis en semillas de tomate. Journal of Applied Microbiology 104:776-786. http://onlinelibrary.wiley.com/doi/10.1111/j.1365-2672.2007.03595.x/epdf consulta en: febrero 2015.

De León, L.; Siverio, F.; López, M.M. y Rodriguez, A. 2008. Comparative effieciency of chemical compounds for in vitro activity against Clavibacter michiganensis subsp. michiganensis, the causal agent of tomato bacterial canker. Crop Protection 27: 1277-1283.

De León, L.; Silverio, F.; López, M.M.; Rodriguez, A. 2011. Clavibacter michiganensis subsp. michiganensis, a seedborne tomato pathogen: healthy seeds are still the goal. Plant disease, 95: 1328-1338.

Dreier, J., Bermpohl, A., y Eichenlaub, R. 1995. Southern hybridization and PCR for specific detection of phytopathogenic Clavibacter michiganensis subsp. michiganensis. Phytopathology 85: 462-468.

Dullahide, S.R.; Moffet, M.L.; Heaton, J.B. y Giles, J. 1983. Effect of time of inoculation of Corynebacterium michiganensis subsp. michiganensis on yield of trellised tomatoes. Australasian Plant Pathology, 12: 15-16. 
Eichenlaub, R.; Gartemann, K-H.; Burger, A. 2006. Clavibacter michiganensis, a group of gram-positive phytopathogenic bacteria. Plant Associated Bacteria Pp. 385-421.

EPPO/ CABI. 1998. Map 253. In: Distribution Maps of Quarantine Pests for Europe (Eds. Smith IM, McNamara DG, Scott PR, Harris KM), CAB International, Wallingford (GB) Pp. 981-985.

EPPO/ CABI 2005. Organisation Européenne et Mediterranéenne pour la Production des Plantes European and Mediterranean Plant Protection Organization. Clavibacter michiganensis subsp. michiganensis. Diagnostics PM 7/42. Bulletin OEPP/EPPO 35 : 271273.

EPPO, 2010. Data Sheets on Quarentine Pests. Clavibacter michiganensis subsp. michiganensis. EPPO A2 List. No 50 Pp 5.

EPPO 2013. Organisation Européenne et Mediterranéenne pour la Production des Plantes European and Mediterranean Plant Protection Organization. Clavibacter michiganensis subsp. michiganensis. Diagnostics PM 7/42. Bulletin OEPP/EPPO 43 : 46-67.

EPPO 2015. EPPO Global Database Clavibacter michiganensis subsp. michiganensis (CORBMI) Consulta: 3/4/15. https://gd.eppo.int/taxon/CORBMI/categorization

Fatmi, M. y Shaad, N.W. 2002. Survival of Clavibacter michiganensis subsp. michiganensis in infected tomato stems under field conditions in California, Ohio and Morocco. Plant Pathology, 51: 149-154.

Faostat. 2013. Food Agricultural Organization of the United Nations. Consulta 10/11/14 http://faostat.fao.org/ 
Fernández-Ruiz, V.; Galiana, L.; Sánchez Mata, M C. 2004. Internal quality characterization of fresh tomato fruits. Hort Science 39: 339-345. En: Fernández Ruiz, v. y col. 2007. Fichas de Revisión: Ingredientes bioactivos de tomate: el licopeno. Revista de Nutrición Clínica y Dietética Hospitalaria No3. Consulta: 3/2/2015 http://hortsci.ashspublications.org/cgi/content/abstract/39/2/339

Francis, DM, Kabelka E, Bell J, Franchino B y Dina S.C. 2001. Resistance to bacterial canker in tomato (Lycopersicon hirsutum LA407) and its progeny derived from crosses to L. esculentum. Plant Disease 85:1171-1176.

Ftayeh, R.M.; von Tiedemann, A. y Rudolph, K.W.E. 2011. A New Selective Medium for Isolation of Clavibacter michiganensis subsp. michiganensis from Tomato Plants and Seed. Phytopathology 101: 1355-1364.

García, M. 2011. El Cinturón hortícola platense: Ahogándonos en un mar de plásticos. Un ensayo acerca de la tecnología, el ambiente y la política. THEOMAI No23. Primer semestre 2011.

García, M; Strassera, M. E.; Luna, M.G.; Polack, L.A.; Mezquíriz, N. 2005. Monitoreo de Plagas: Análisis técnico-económico en una producción de tomate bajo invernáculo del Cinturón Hortícola Platense. Boletín Hortícola. Año 10, Número 31. INTA-Facultad de Ciencias.Agrarias y Forestales, UNLP-MAA.

Garnsey, S. y Cambra, M . 1991. Enzyme-linked immunosorbent assay ELISA for citrus pathogens. In Graft-Transmissible Diseases of citrus. Handbook for detection and diagnosis. C.N. Roistacher, Ed. Roma, FAO Pp. 193-216. 
Gartemann, K.-H., Kirchner, O., Engemann, J., Gräfen, I., Eichenlaub, R., y Burger, A. 2003. Clavibacter michiganensis subsp. michiganensis: First steps in understanding of virulence of a gram-positive phytopathogenic bacterium. Journal of Biotechnology 106:179-191.

Gartemann, K.-H., Abt, B., Bekel, T., Burger, A., Engemann, J., Flügel, M., Gaigalat, L., Goesmann, A., Gräfen, I., Kalinowski, J., Kaup, O., Kirchner, O., Krause, L., Linke, B., McHardy, A., Meyer, F., Pohle, S., Rückert, C., Schneiker, S., Zellermann, E.-M., Pühler, A., Eichenlaub, R., Kaiser, O. y Bartels, D. 2008. The genome sequence of the tomatopathogenic Actinomycete C. michiganensis subsp. michiganensis NCPPB382 reveals a large island involved in pathogenicity. Journal of Bacteriology 190:2138-2149

Gerster, H.1997. The potential role of lycopene for human health. The Journal of American College of Nutrition, 16: 109-126.

Gitaitis, R. D.1990. Induction of a hypersensitive like reaction in four-o'clock by Clavibacter michiganensis subsp. michiganensis. Plant Disease 74: 58-60.

Gitaitis, R. D., Beaver, R.W., y Voloudakis, A. E. 1991. Detection of Clavibacter michiganensis subsp. michiganensis in symptomless tomato transplants. Plant Disease 75: 834-838.

Gleason, M.L., Braun, E.J., Carlton W.M. y Peterson, R. H. 1991. Survival and dissemination of Clavibacter michiganensis subsp. michiganensis in tomatoes. Phytopathology 81: 1519-1523.

Gleason, M.L., Gitaitis, R.D., y Ricker, M.D. 1993. Recent progress in understanding and controlling bacterial canker of tomato in Eastern Notrh America. Plant Disease 77: 10691076. 
Gorris, M.T.; Cambra, M. ; Lecompte, P. ; Llop, P. ; Chartier, R. ; Paulin, J.P. ; López, M.M. 1996. A sensitive and specific detection of Erwinia amylovora based on the ELISADASI enrichment with monoclonal antibodies. Acta Horticulturae 411 : 41-46.

Goszczynska, T., Serfontein, J. J., y Serfontein, S. 2000. Introduction to Practical Phytobacteriology First edition, Safrient, Pretoria-South Africa. Pp. 83.

Gregersen, T. 1978. Rapid method for distinction of Gram-negative from Gram-positive bacteria. European Journal of Applied Microbiology and Biotechnology, 5: 123-127.

Gross, D.C. y Vidaver, A. K. 1979. A semiselective médium for isolation of Corynebacterium nebraskense from soil and plant parts. Phytopathology 69:82-87. Citado en Fatmi, M and Schaad, W. 1988. Semiselective Agar Medium for Isolation of Clavibacter michiganense subsp. michiganense from Tomato Seed. Phytopathology $78: 121-126$.

Hausbeck, M.K.; Bell, J.; Medina-Mora, C.; Podolsky, R. y Fulbright, D.W. 2000. Effect of Bactericides on Population Sizes and Spread of Clavibacter michiganensis subsp. michiganensis on Tomatoes in the Greenhouse and on Disease Development and Crop Yield in the Field. Phytopathology, 90: 38-44.

Holt, J. G.; Krieg, N.R. ; Sneath, P.H.A. ; Staley, J.T. y Williams, S.T. 1994. Bergey's Manual of Determinative Bacteriology. 9th., ed. W.R. Hensyl. Baltimore : Williams and Wilkins, Pp. 787.

Hugh, R. y Leifson, E. 1953. The taxonomic significance of fermentative vs. oxidative metabolism of carbohydrates by various Gram negative bacteria. Journal of Bacteriology 66: $24-26$. 
Infostat. 2009. Di Rienzo J.A., Casanoves F., Balzarini M.G., Gonzalez L., Tablada M., y Robledo C.W. InfoStat. Grupo InfoStat, FCA, Universidad Nacional de Córdoba, Argentina.

INTA y CMCBA. 2009. Instituto Nacional de Tecnología Agropecuaria y Corporación del Mercado Central de Buenos Aires. 2009. Boletín electrónico de tomate $\mathrm{N}^{\circ} 18$. Consulta 10/10/14 http://www.mercadocentral.gob.ar/boletin/pdf/Tomate18.pdf

INTA. 2011. Instituto Nacional de Tecnología Agropecuaria. Desarrollo de tecnologías que mejoren la competitividad del tomate. Consulta 23/11/14 http://inta.gob.ar/proyectos/pnhfa-061221

Jahr, H.; Bahro, R.; Burger, A.; Ahlemeyer, J. y Eichenlaub, R. 1999. Interactions between Clavibacter michiganensis and its host plants. Environmental Microbiology 1: 113-118.

Janse, J.D. 2006. Phytobacteriology, Principles and Practice. Plant Protection ServiceWageningen-The Netherlands. CABI Publishing, Pp. 368.

Jaramillo, J.; Rodriguez, V. P.; Guzmán, M.; Zapata. M. y Rengifo, T. 2007. Manual Técnico: Buenas Prácticas Agrícolas en la Producción de Tomate Bajo Condiciones Protegidas, Mana, Corpoica, Centro de Investigación "La Selva”. FAO, Gobernación de Antioquia.

Jones, J.B.; Jones, J.P.; Stall, R.E. y Zitter, T.A. 2001. Plagas y Enfermedades del Tomate. Sociedad Americana d Fitopatología. Ed. Mundi-Prensa, España Pp. 26-32.

Kabelka, E. Franchino, B. y Francis, D.M. 2002. Two loci from Lycopersicon hirsutum LA407 confer resistance to strains of Clavibacter michiganensis subsp. michiganensis. Phytopathology 92:504-510. 
Kado, C.I. 2010. Plant Bacteriology. University of California, APS PRESS pp 336.

Kawaguchi A.; Tanina, K. y Inoue, K. 2010. Molecular typing and spread of Clavibacter michiganensis subsp. michiganensis in Greenhouses in Japan. Plant Pathology, 59:76-83.

Kawaguchi A. y Tanina, K. 2014. Genetic groups of Clavibacter michiganensis subsp. michiganensis identified by DNA fingerprinting and the effects of inoculation methods on disease development. European Journal of Plant Pathology 1: 399-406.

Kleitman, F.; Barash, I.; Buerger, A.; Iraki, N.; Falash, Y.; Sessa, G.; Weinthal, D.; Chalupowics, L.; Garteman, K.H.; Eichenlaub, R.; Sasson, S. M. 2008. Characterization of a Clavibacter michiganensis subsp. michiganensis population in Israel. European Journal of Plant Pathology 121: 463-475.

Leigh, J. A. y Coplin, D. L. 1992. Exopolysaccharides in plant bacterial interactions. Annual Review of Microbiology, 46: 307-346.

López, M.M. ; Cambra, M. ; Aramburu, J. M. y Bolinches, J. 1987. Problems of detecting phytopathogenic bacteria by ELISA. Bulletin OEPP/EPPO Bulletin, 17 : 113-118.

López, M.M. y Cambra, M. 1996. Diagnóstico y Detección de Bacterias Fitopatógenas, Capítulo 17, 587-625pp. En : Llácer, G.; López, M.M.; Trapero, A. ; Bello, A. PatologíaVegetal. Tomo I, Sociedad Española de Fitopatología,Phytoma-MundiPrensa.

Madden, L. V.; Hughes, G. y van der Bosch, F. 2007. The Study of Plant Disease Epidemics. APS Press Pp. 421.

March, J. G.; Oddino, C.M. y Marinelli, A.D. 2010. Manejo de Enfermedades de los Cultivos según parámetros Epidemiológicos. Edición INTA-UNRC, Pp. 193.

Mc Manus, P. 1999. Uso de antibióticos en el control de enfermedades de las plantas. Enfermedades Infecciosas y Microbiológicas 19:.192-196. 
Mercaddo Central de Buenos Aires. 2011. Ficha Técnica: Tomate (Lycopersicum esculentum Mill) En: http://www.mercadocentral.gob.ar/ziptecnicas/FichaTecnica-Tomate.pdf

Obregón, V.; Flores, C.R.; Galdeano, E.; Colombo, H. y Flores Alzaga, D. 2011. Aislamiento e Identificación por PCR de Clavibacter michiganensis subsp. michiganensis en cultivos de tomate del NOA. $2^{\circ}$ Congreso de Fitopatología. Mar del Plata. Argentina. Libro de Resúmenes: 93.

OMS. 2005. Organización Mundial de la Salud. Manual de Bioseguridad en el laboratorio. Tercera Edición, Ginebra, pp.223.

Ozdemir, Z. 2005. Development of a Multiplex PCR Assay for Concurrent Detection of Clavibacter michiganensis subsp. michiganensis and Xanthomonas axonopodis pv. vesicatoria. Plant Pathology Journal 4: 133-137.

Pastrik, K.H. and Rainey, F. A. 1999. Identification and differentiation of Clavibacter michiganensis subspecies by polymerase chain reaction based techniques. Journal of Phytopathology 147: 687-693.

Peralta, I.E. y Spooner, D. M. 2006. History, origin and early cultivation of tomato (Solanaceae). IN: Razdan, M.K. and Matoo, A.K. (Ed.) Genetic Improvement of solanaceous Crops. Vol 2: Tomato. P.1-24. Science Publishers, USA

Peralta, I. E.; Knapp, S.; Spooner, D. M. 2005. New species of wild tomatoes (Solanum section Lycopersicon: Solanaceae) from Northern Peru. Systematic Botany 30: 424-434.

Pérez, G.M.; Márquez, S.F.; Peña, L.A.1997, Mejoramiento de las hortalizas. Universidad Autónoma de Chapingo. México.380p. En: Alvarez-Hérnandez y col. 2009. Incidencia de plagas en injertos de jitomate (Solanum lycopersicum) sobre plantas silvestres. Revista Colombiana de Entomología 32: 150-155. 
Poissenier, J. y Rat, B. 1993. Le Chancre bacterién de la tomate. Infos-Techniques, Centre Technique Interprofessionel des Fruits et légumes (Ctfil), 96: 29-32.

Poysa, V. 1993. Evaluation of tomato breeding lines resistant to bacterial canker. Canadian Journal of Plant Pathology 25: 301-314.

Rat, B.; Poissonier, J.; Goisque, M.J. y Burgaud, A. 1991- Le point sur le chancre bacterién. Fruits et Légumes $86: 38-40$.

Ricker, M.D. y Riedel, R.M. 1993. Effect of Secondary Spread of Clavibacter michiganensis subsp. michiganensis on Yield of Northern Processing Tomatoes. Plant Disease 77: 364-366.

Rista, L.; Sillon, M y Favaro, J.C. 2004. Importancia de la vía de penetración de Clavibacter michiganensis subsp. michiganensis en el desarrollo del cancro bacteriano en tomate. XXVII Congreso Argentino de Horticultura. Merlo, San Luis.

Rista, L.; Sillon, M.; Favaro, J.C. y Buyatti, M. 2005a. Influencia de la poda en la Incidencia del cancro bacteriano del tomate. XIII Congreso Latinoamericano de Fitopatología. III Taller de Asociación Argentina de Fitopatólogos. Villa Carlos Paz, Córdoba. Libro de Resúmenes: 217.

Rista, L.; Sillon, M.; Favaro, J.C. y Buyatti, M. 2005b. Dispersión de Clavibacter michiganensis a través de la poda. XII Congreso Latinoamericano y XXVIII Congreso Argentino de Horticultura. General Roca, Río Negro.

Romero, A. M.; Zapata, R. y Ollua, F. 2011. Nisina: Una bacteriocina para el manejo del cancro bacteriano del tomate. $2^{\circ}$ Congreso de Fitopatología. Mar del Plata. Argentina.

Libro de Resúmenes pág.267. 
Romero, A.M.; Correa, O.S.; Moccia, S. y Rivas, J.G.2003. Effect of Azospirillummediated plant growth promotion on the development of bacterial diseases on fresh-market and cherry tomato. Journal of Applied Microbiology, 95: 832-838.

Sánchez-Vizcaíno, J.M. y Cambra, M. 1981. Técnicas inmunoenzimáticas en patología animal y vegetal. Instituto Nacional de Investigaciones Agrarias, Colección Monografías No. 29, Ministerio de Agricultura, Madrid, España.

Sen, Y.; van der Wolf, J.; Visser, R. y van Heusden, S. 2015. Bacterial Canker of Tomato: Current Knowledge of Detection, Management, Resistance and Interactions. Plant Pathology 99: 4-13.

Schaad, N. W., and Frederick, R. D. 2002. Real-time PCR and its application for rapid plant disease diagnostics. Canadian Journal of Plant Pathology 24: 250-258

Schaad, N. W., Jones, J. B. y Chun, W. 2001. Laboratory guide for identification of plant pathogenic bacteria. American Phytopathological Society, St. Paul, MN

Schaad, N.W.; Jones, B. and Chun, W. 2000. Laboratory Guide for Identification of Plant Pathogenic Bacteria. Ed APS Press. USA

Sharabani, G.; Lofthouse, M.; Chalupowicz, L. and Shtienberg, D. 2013. The significance of guttation in the secondary spread of Clavibacter michiganensis subsp. Michiganensis in tomato greenhouses. Plant Pathology 62: 578-586.

Sharabani, G.; Shtienberg, D.; Borenstein, M.; Shulhani, R.; Lofthouse, M.; Sofer, M.; Chalupowicz, L. Barel. V. y Manulis-Sasson, S. 2012. Effects of plant age on disease development and virulence of Clavibacter michiganensis subsp. michiganensis on tomato. Plant Pathology Pp. 1-9. 
Shaner, G. y Finney, R.E. 1977. The effect of nitrogen fertilization on the expression of slow mildewing resistance in knox wheal. Phytopathology 67: 1051-1056

Shirakawa, T., Sasaki, T., y Ozaki, K. 1991. Ecology and control tomato bacterial canker and detection methods of this pathogens. Japan Agricultural Research Quarterly 25: 27-32.

Seebold, K. 2008. Bacterial Canker of Tomato. Plant Pathology Fact Sheet. Cooperative Extension Service. University of Kentucky, Agricultural and Natural Resources.

Sillón, M.R.; Herzog, L.J.; Rista, L.M. 1997. Clavibacter michiganensis subsp. michiganensis en tomate bajo invernadero. Determinación de la capacidad de penetración por flores. XX Congreso Argentino de Horticultura. Bahía Blanca, Buenos Aires. Libro de Resúmenes : 106.

Smith, E. F. 1910. A new tomato disease of economic importance. (Abstr.). Science (N.S.) 31:794-796.

Strassera, M. E. 2006. Características bioecológicas de Bemisia tabaci (Gennadius) y su peligrosidad como plaga en el cultivo de pimiento. Boletín Hortícola 11:35-39.

Strider, D. L. 1970. Tomato seedling inoculation with Corynebacterium michiganense. Plant Disease Reporter 54: 36-39.

Sutula, C.L. ; Gillet, J.M. ; Morrisey, S.M. and Ramsdell, D.C. 1986. Interpreting ELISA data establishing the positive- negative threshold. Plant Disease 70 : 722-726.

Tancos, M. A., Chalupowicz, L., Barash, I., Manulis-Sasson, S. y Smart, C. D. 2013. Tomato fruit and seed colonization by Clavibacter michiganensis subsp. michiganensis through external and internal routes. Applied and Environmental Microbiology 79:69486957. 
Torres L.; Rojas H., L. F.; Mazo R., J. C.; Sampedro, C.; Restrepo G., S.; Atehortúa G., L.; Álvarez M., C. D.; Ríos E., R. 2003. Estudio de medios de cultivo para la síntesis de licopeno a partir de Clavibacter michiganensis subsp. michiganensis 10: 37-45 Universidad de Antioquia Medellín, Colombia.

USDA. 1999. Nutrient Data laboratory for Standard Reference.U.S. Department of Agriculture, Agricultural Research Service. Beltsville Human Nutrition Research Center. NDL Bulletin Board, 301: 734-5078. En: Fernández Ruiz, v. y col. 2007, Fichas de Revisión: Ingredientes bioactivos de tomate: el licopeno. Revista de Nutrición Clínica y Dietética Hospitalaria N³, vol. XXVII/166. Departamento Nutrición y Bromatología II. Bromatología. Facultad de Farmacia. Universidad Complutense de Madrid-España.

Vega, D.; Morris, M.; Del Fueyo, P.; Zapata, R. L. y Romero, A.M. 2011a.Tratamiento térmico de semillas de tomate. Método de desinfección efectivo para el control de Clavibacter michiganensis subsp. michiganensis. XXIV Congreso Argentino de Horticultura. Buenos Aires, Argentina. Libro de Resúmenes: 363.

Vega, D.; Romero, A.M.; Zapata, R. y Seoane, M.B. 2011b. Relación entre Clavibacter michiganensis subsp. michiganensis en rastrojos de tomate y su tasa de descomposición. $2^{\circ}$ Congreso Argentino de Fitopatología. Mar del Plata. Argentina. Libro de Resúmenes: 190.

Vega, D.; Romero,A.M.; Zapata, R.L. y Morales, F. 2010. Supervivencia de Clavibacter michiganensis subsp. Michiganensis en rastrojos de tomate (Solanum lycopersicum L.) XXXIII Congreso Argentino de Horticultura. Rosario. Libro de Resúmenes: pág.397

Vega, D., Romero, A., Zapata, R. y Arienza,P. 2009. Desinfección de Herramientas de poda para el Manejo del Cancro Bacteriano del Tomate. XII Jornada Fitosanitarias de Fitopatologìa, Santiago del Estero, Argentina. Libro de Resúmenes.- 
Wallis, F.M. 1977. Ultrastructural histopathology of tomato plants infected with Corynebacterium michiganense. Physiological plant Pathology 11: 333-342.

Walker, J.C. y Kendrick, J.B. Jr. 1948. Plant nutrition in relation to disease development. IV. Bacterial canker of tomato. American Journal of Botany 35: 186-192.

Werner, N.A.; Fulbright, D. W.; Podolsky, R.; Bell, J. y Hausbeck, M.K. 2002. Limiting populations and spread of Clavibacter michiganensis subsp. michiganensis on seedling tomatoes in the greenhouse. Plant Disease, 86: 535-542.

Xu, X.; Rajashekara, G.; Paul, P.A. y Miller, S.A. 2012. Colonization of tomato seedling by bioluminescent Clavibacter michiganensis subsp. michiganensis under diferente humidity regimes. Phytopathology, 102: 177-184.

Yim, K.-O.; Lee, S.-D.; Cho, J.-H.; Cha, J.-S.2011. Characterization of phenotypic variants of Clavibacter michiganensis subsp. michiganensis isolated from Capsicum annuum.

Zaluga, J., Van Vaerenbergh, J., Stragier, P., Maes, M., y De Vos, P. 2013. Genetic diversity of non-pathogenic Clavibacter strains isolated from tomato seeds. Systematic Applied Microbiology 36:426-435.

Zembo, J.C. 1998. El negocio Hortícola Argentino. Visión sobre la evolución desde el mercado y la tecnología. Texto de la disertación efectuada en Rosario. 